DOI: $10.24275 /$ uama. 7021.7533

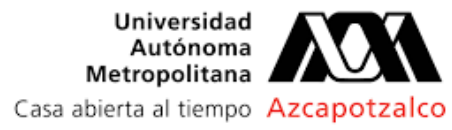

Universidad Autónoma Metropolitana Unidad Azcapotzalco

División de Ciencias Sociales y Humanidades

\title{
Análisis y propuesta con perspectiva de género para la materia de Literatura Mexicana e Iberoamericana de la Escuela Nacional Preparatoria
}

\author{
Tesis \\ que para obtener el grado de \\ Maestra en Literatura Mexicana Contemporánea \\ presenta:
}

Dagny Ludmila Valadez Valderrábano

Asesores: Dr. Alejandro Caamaño Tomás y Mtra. Lidia García Cárdenas Lectora: Dra. Raquel Mosqueda Rivera

Esta investigación recibió el apoyo de la beca que otorga el Consejo Nacional para la Ciencia y Tecnología a estudiantes de los programas incorporados al Padrón de Posgrados de Calidad 


\section{A Mane, Pai, Mai y Toniness}

"La campiña está bien crema, digo bien verde, los árboles en flor de la viñas solo se ven los tronquitos con unas cuantas hojitas." Ludmilla Valderrábano Jölsen

"En la mañana vi tu retrato, lo vi con tanto cariño, como si fuera lo único que me quedara tuyo y luego me di cuenta de que no es lo único, porque tengo tu cariño, tu retrato y una pregunta." Ricardo Valadez 
Agradecimientos

Cuando uno escribe agradecimientos siempre algo sale mal, no obstante, deseo agregarlos. En este caso, organicé mis agradecimientos según el orden cronológico en el que se sucedieron los eventos que me permitieron terminar este trabajo

Agradezco a Alejandra Sánchez Valencia el que me haya invitado a conocer la Universidad Autónoma Metropolitana y guiara mis primeros recorridos en ella. A Christian Sperling, quien en una plática de pasillo me dio las pistas necesarias para llegar al Posgrado en la que hoy es en mi casa, La UAM Azcapotzalco. A mis tutores, Alejandro Caamaño y Lidia García, quienes desde la entrevista confiaron en mi y mantuvieron esa postura a lo largo de dos años en los que hubo algunos baches, pero siempre tuvieron palabras amables y a la vez duras para apoyarme en el proceso de la tesis y en los momentos complicados. A Lucia Tomasini, Ociel Flores y Christine Hüttinger, que estuvieron ahí de distintas maneras, siempre con una actitud positiva, invaluable en momentos difíciles.

Agradezco a mis compañeros, en especial a Claudia Gil, el trabajo en equipo y las clases que hicieron de la maestría uno de los periodos más entrañables de mi vida escolar

De manera muy especial agradezco a Carlos Warden la compañía, la paciencia, las lecturas compartidas y el apoyo incondicional en todos los proyectos personales y profesionales. No puedo dejar de mencionar a mi familia, que a pesar de que a veces la dejo un poco abandonada, siempre está ahí: Ludmilla Valadez, Dagni Valderrábano, Dolores Valderrábano, Ricardo Holm, Lizette Warden y Aurelia Rivera.

En particular, agradezco a Tessa, mi compañera de desvelos y de alegrías de 13 años, mi guardiana en la redacción de esta tesis, y quien no ha podido estar para ver la culminación de este trabajo. Con mucho cariño a la Tesaura. 


\section{Índice}

CAPÍTULO I. LOS ESTUDIOS DE GÉNERO ........................................................................................................11

$1.1 \quad$ LOS INICIOS DE LOS ESTUDIOS DE GÉNERO ………………………………………..... 11

1.2 LOS ESTUDIOS DE GÉNERO EN MÉXICO ............................................................................... 33

CAPÍTULO II. ANÁLISIS DEL PROGRAMA DE LITERATURA MEXICANA E IBEROAMERICANA. 41

2.1 ANÁLISIS HISTÓRICO DE LA MATERIA DE LITERATURA MEXICANA E IBEROAMERICANA............ 41

2.2 ANÁLISIS DE LOS OBJETIVOS DEL PROGRAMA DE LITERATURA MEXICANA E IBEROAMERICANA56

2.3 ANÁLISIS DE LOS OBJETIVOS ESPECÍFICOS Y PARTICULARES DEL PROGRAMA ......................... 71

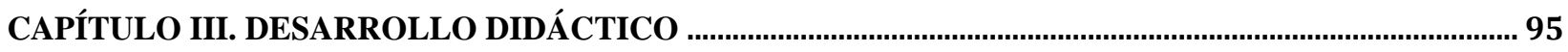

3.1 PROPUESTA DE ORGANIZACIÓN DE AUTORES...................................................................... 95

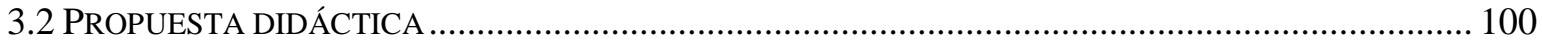

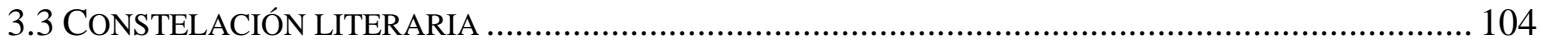

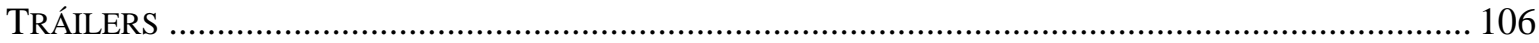

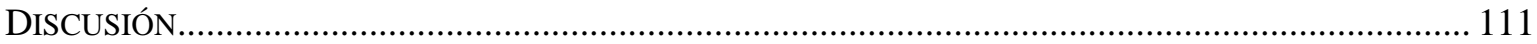

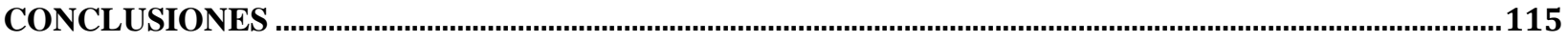

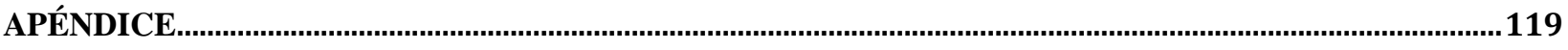

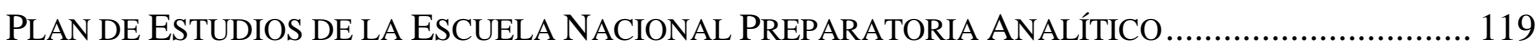

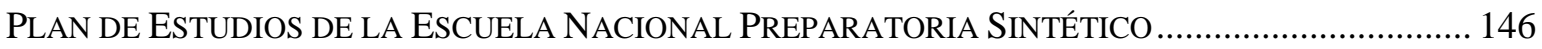

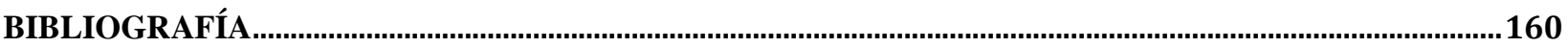




\section{Introducción}

En la actualidad, los movimientos socio-culturales viajan alrededor del mundo occidentalglobalizado de forma vertiginosa a través de los diferentes medios de comunicación; como resultado, los países conectados entre sí, tienen preocupaciones afines, pese a las características particulares de cada uno. Entre algunas de las preocupaciones compartidas se encuentran: la falta de equidad de género y la reivindicación de grupos históricamente marginados: las personas de color y los miembros de la comunidad LGBT, entre otros; es decir, hay una crítica global al sistema blanco hétero-patriarcal que ha dominado la sociedad occidental por siglos.

Uno de los movimientos precursores de la ya mencionada crítica social contemporánea es el feminismo, cuyas propuestas han devenido teóricamente en lo que ahora conocemos como los Estudios de Género. En la actualidad, estos no sólo ofrecen una forma diferente de analizar los hechos históricos, sino que se han convertido en parte importante de una línea de acción política instrumentada desde organizaciones internacionales como la ONU y el Consejo de la Unión Europea, que buscan lograr equidad de género en las instituciones de educación superior y, como consecuencia, en la producción de ciencia y en la sociedad en general.

La gran disparidad entre hombres y mujeres en todos los niveles del campo académico quedó en evidencia a través de estadísticas diseñadas y presentadas de forma oficial por el grupo de Helsinki ${ }^{1}$ en 1999; años más tarde, en la reunión de Beijing, en 2012, se establecieron medidas que buscaban reducir la brecha entre hombres y mujeres. La presente investigación se inserta en una de las directrices marcadas por estos organismos, la cual especifica que una de las acciones

\footnotetext{
${ }^{1}$ Grupo fundado por la Comisión de Europa que reúne a mujeres dedicadas a la ciencia de 15 países de la Unión Europea.
} 
ejecutivas que se deben tomar para lograr la equidad de género es la inclusión de investigaciones elaboradas por mujeres. ${ }^{2}$

A partir de la lectura de dichas directrices comencé a preguntarme: ¿hasta dónde debemos intervenir para alcanzar los objetivos de equidad e igualdad y participar desde nuestras trincheras en estas medidas internacionales? Después de pensarlo mucho y analizar los elementos de trabajo diario, como los programas de estudio de diferentes materias, me di cuenta de que no hay mujeres, o no suficientes como para hablar de una representatividad. Entonces, la pregunta que surge y que guía todo este trabajo es: ¿cómo se puede integrar a más mujeres en un programa de estudios y a la vez incluir una perspectiva de género en la discusión de los textos propuestos? Este trabajo es la búsqueda de la respuesta a dicha interrogante.

Por lo tanto, en congruencia con los lineamientos internacionales y a partir del cuestionamiento que hago desde mis reflexiones personales, en este texto busco una forma didáctica y no invasiva para integrar la perspectiva de género en el programa de estudios de la materia de Literatura Mexicana e Iberoamericana de la Escuela Nacional Preparatoria para, al mismo tiempo, conseguir una mayor paridad en cuanto al número de textos escritos por hombres y por mujeres en las lecturas. Para lograr mi objetivo llevaré a cabo una investigación documental que me permite trazar la historia de los Estudios de Género en México y estudiar sus planteamientos, revisar la historia de la materia de literatura, integrar las propuestas teóricas de los Estudios de Género a la visión general del programa y elaborar una nueva propuesta de lecturas.

La historia de los Estudios de Género en México se inicia alrededor de 1840 con una lenta evolución en comparación con los cambios en otras partes del mundo, hasta llegar a los trabajos académicos de nuestros días. Para este texto mencionaré los momentos más importantes de esta

\footnotetext{
${ }^{2}$ M. Brouns, "Gender and the Assesment of Scientific Quality", pp. 147-154.
} 
transformación y haré especial énfasis en lo que se relaciona con los proyectos educativos a nivel preparatoria.

A diferencia del tema de los Estudios de Género, la enseñanza de la literatura en México cuenta con mucha más información: se puede documentar desde la época colonial, seguir su desarrollo y, sobre todo, analizar la importancia de la literatura en la educación nacional. Los planes de estudio - para ser más específica, los mapas curriculares- de la Escuela Nacional Preparatoria (ENP) están disponibles desde 1886 y los programas desglosados - o lo que se conoce como programas indicativos- se encuentran a partir de 1922 en el archivo histórico de la ENP, resguardado por el Instituto de Investigaciones sobre la Universidad y la Educación (IISUE), donde, además, se encuentran actas, oficios, records de asistencia de profesores y alumnos, gastos y otro tipo de documentación que evidencia los cambios que ha tenido la orientación de la educación en la ENP y en la que se puede observar el proceso de adecuación de ésta a la realidad nacional.

En lo que respecta a la elaboración de mi tesis, este archivo fue de gran utilidad para analizar el proceso de incursión de la figura femenina en la lista de lecturas propuestas dentro de la materia de literatura y, al mismo tiempo, de forma tangencial, para cuestionar la o las miradas que dictan la selección de dichas lecturas, pues, en algunos casos, los documentos muestran quiénes participaban en las decisiones académicas.

El interés personal para realizar esta investigación nace de reflexiones hechas a partir de los diferentes roles en los que me he desenvuelto dentro del campo académico: como profesora de nivel medio superior desde hace más de 19 años, he notado la falta de nociones generales sobre literatura entre mis alumnos y he constatado el poco conocimiento que tienen respecto a autoras. Desde mi posición de docente de Lengua Extranjera, es más sencillo notar estas deficiencias, ya que se requiere el uso de muchos ejemplos para enseñar una lengua y generalmente recurro a textos 
literarios y, como mi materia es Inglés, no Literatura, los alumnos no se sienten juzgados o intimidados cuando pregunto datos sobre sus lecturas, autores, funciones de la lengua, comprensión del texto o simplemente si existe el gusto por la lectura; al no existir una relación de autoridad, comparten sus experiencias abiertamente.

Asimismo, tuve la oportunidad de convivir con mis alumnos de bachillerato durante ciclos escolares completos, lo cual me permitió entablar una relación muy cercana con ellos y conocer las problemáticas sociales a las que se enfrentan; $\mathrm{y}$, en casos muy específicos, pude apreciar los conflictos que llegan a surgir cuando algunas de las ideas tradicionales que aprenden en sus hogares son confrontadas por las realidades que viven otros de sus compañeros.

Como resultado de mis observaciones, que no son más que la evidencia de un contexto social agreste que ya ha sido definido en varias investigaciones, ${ }^{3}$ considero que existe una apremiante necesidad de actualizar los programas de estudio, integrando la perspectiva de género como medio para llevarlos al reconocimiento de las necesidades de una sociedad en la cual es urgente ser más incluyente y en la que la discriminación social, la brecha de género laboral, el acoso y la violencia de género, entre otros, son problemas cotidianos. La búsqueda de cambio siempre lleva consigo un fuerte choque que, en este caso, se da por la transgresión de dogmas culturales y, al mismo tiempo, se acentúa debido al conflicto generacional. Por lo anterior, para lograr una transformación, se requiere la participación activa de todos los actores sociales.

En las primeras líneas de esta investigación, muestro cómo los cambios en el ramo de la educación se realizan de forma muy lenta, debido a cuestiones burocráticas y a la larga tradición sustento de su funcionalidad. En México, las políticas educativas y los programas académicos no están acordes a la dinámica de la sociedad. Aparte de los movimientos culturales internacionales

\footnotetext{
${ }^{3}$ José del Tronco, "Violencia escolar en México: una exploración de sus dimensiones y consecuencias".
} 
que llegan a nosotros a través de distintos medios, es necesario hacer referencia a las políticas y a las relaciones sociales de la colectividad nacional, las cuales repercuten de forma directa en el acontecer diario de los estudiantes.

Una dinámica significativa es la visibilización y, a la vez, la normalización de la violencia en México. Pese a la gran variedad de factores económicos, sociales, culturales y políticos que provocan el aumento de la violencia de género a nivel mundial, desde mi perspectiva, el parteaguas en México fue la declaración de la llamada "guerra contra el narcotráfico" en el año 2006, que tuvo como consecuencia el incremento en la exposición de la población a eventos violentos y, con ello, a procesos súbitos de transformación social y cultural. Para el ciclo escolar que inició en agosto de 2018, los alumnos que ingresan a primero de secundaria y que cuentan con 11 o 12 años han vivido toda su infancia en un entorno en el que términos como asesinato, ajuste de cuentas, daño colateral y feminicidio se utilizan de manera regular.

Es así como ya toda una generación ha crecido en un ambiente violento en el que, además, se ha exacerbado la violencia en contra de las mujeres. Una evidencia de esto son las catastróficas cifras publicadas por la ONU en el marco del Día Internacional de la Eliminación de la Violencia contra la Mujer 2016, en las que se observa que:

A nivel mundial, al menos una de cada tres mujeres ha sufrido violencia física o sexual, principalmente por parte de su pareja, y en México, el 47\% de las mujeres ha sido víctima por parte de su pareja. En el país, una de cada cinco mujeres ha sido víctima de violencia en el ámbito laboral. En 2015, se registraron en promedio 6.2 asesinatos de mujeres al día en México. ${ }^{4}$

En el mismo documento se encuentra la entrevista a Ana Güezmes, representante de ONU Mujeres en México, quien de manera contundente plasma la gravedad del asunto cuando califica la violencia

\footnotetext{
${ }^{4}$ Ana Güezmes, "Violencia contra mujeres y niñas, pandemia mundial".
} 
contra las mujeres como pandemia mundial, ya que "la violencia [contra las mujeres] provoca más muertes que la tuberculosis, la malaria y todos los tipos de cáncer juntos.",5

Si bien hemos tenido avances en las políticas de género y se han creado campañas para sensibilizar a las personas en cuanto a la violencia hacia las mujeres, es necesario hacer más e intentar llevar a cabo cambios más profundos con alcances en el futuro, acordes con líneas internacionales. Por ejemplo, considero indispensable revisar qué es lo que se está enseñando en las aulas e integrar las propuestas de los Estudios de Género en los contenidos específicos de cada materia.

La pertinencia de la presente investigación radica en que la generación que ha crecido en la violencia estará ingresando a las aulas de la ENP en agosto de 2021. Se puede decir que apenas tenemos tiempo para tratar de adecuar nuestros planes de estudio a la realidad de estos alumnos. En este sentido, se hace necesario mencionar que, durante el proceso de elaboración de esta tesis, se modificó el Programa de la ENP y, pese a cambios importantes, como la adición de una unidad dedicada a la producción femenina en las letras mexicanas y latinoamericanas, este trabajo se hace aún más necesario, ya que en dicho programa no se integra una perspectiva de género, sino que se hace una inclusión que fomenta la división y no la inclusión de distintas perspectivas.

Los objetivos específicos de la presente tesis son: 1) evidenciar la necesidad urgente de revisar nuestros programas a través de una visión de género para reflexionar sobre paradigmas sociales; 2) presentar una secuencia didáctica que permita a los profesores incluir la perspectiva de género en sus clases, sin que sea un elemento disruptivo, a través de dos estrategias: la primera son las constelaciones literarias basadas en las investigaciones de Guadalupe Jover y la segunda es la socialización de las reflexiones de los alumnos por medio de la propuesta denominada "Dime" de

${ }^{5}$ Loc. cit. 
Adain Chambers; 3) proponer un orden diferente a las lecturas con el fin de demostrar que los textos escritos tanto por hombres como por mujeres cubren una gran variedad de temas y que pueden ser leídos desde diferentes perspectivas.

El trabajo está dividido en tres capítulos: en el primero, se plantea el marco teórico que será la directriz para analizar los programas, los textos y la propuesta didáctica. El segundo es propiamente el análisis histórico de la materia y el desarrollo práctico de una constelación literaria planteada en los objetivos generales y particulares, así como la propuesta de los conocimientos esperados; y el tercero presenta la secuencia didáctica y la reorganización de lecturas propuestas.

Para comenzar mi investigación, haré una breve revisión de la historia de los Estudios de Género en México, así como de la enseñanza de la literatura en la educación media superior, para lo cual es necesario mencionar los orígenes de la ENP. Una vez establecida la pertinencia de la materia, se especifica la razón por la que un estudio desde la perspectiva de género es indispensable para actualizar los planes y adecuarlos a la realidad de la sociedad mexicana contemporánea. Es importante mencionar que no sólo se toman en cuenta las propuestas de los Estudios de Género, sino que, de manera paralela, se desarrolla un análisis literario que justifica la reorganización de los textos y la secuencia didáctica.

Como ya lo he expuesto, mi trabajo tiene como hilos conductores las premisas de los Estudios de Género y un riguroso análisis literario que, en equilibrio, llevan a la elaboración de un ejercicio académico transversal. En cuanto a las investigaciones relacionadas con la primera de estas líneas rectoras, pese a la promulgación de políticas nacionales a favor de la equidad de género, la formación de centros de investigación con el objetivo de trabajar sobre los Estudios de Género y la creación de programas de licenciatura y posgrado dedicados a este tipo de temas, los trabajos académicos que se producen en nuestro país no son suficientes para abarcar todos los ámbitos sociales. 
Veremos que en el tema motivo de este texto, los Estudios de Género en los programas de Literatura Mexicana e Iberoamericana de la ENP, las fuentes son casi inexistentes; en la búsqueda realizada, no encontré ningún trabajo al respecto. Sí existen varias tesis sobre los procesos de enseñanza-aprendizaje y la actualización de las estrategias educativas, pero ninguno menciona la inclusión de la perspectiva de género. Hay textos que abordan el tema de manera general, por ejemplo, el de Rebeca Caballero titulado "El diseño curricular como estrategia para la incorporación de la perspectiva de género en la educación superior”, en el que trata la complejidad que conlleva la elaboración de programas académicos con un enfoque de género en el nivel superior. El trabajo más cercano a mi propuesta es una tesis de 2017 de la Maestría en Docencia para la Educación Media Superior de la UNAM, escrita por María Inés Cortés Pérez, que se titula “La perspectiva de género: una propuesta didáctica para enriquecer la literatura en el bachillerato". Este trabajo tiene un acercamiento muy similar al que aquí señalo, no obstante, sus premisas son muy diferentes. El campo de estudio es en el sistema educativo del Estado de México y plantea un enfoque basado en proyectos: esto quiere decir que se busca la creación de un objeto tangible. Es decir, comprender las ideas de la perspectiva de género y aplicarlas en un proyecto que sea útil a la comunidad. Por el contrario, yo busco incluir la perspectiva de manera más sutil integrándola de forma que logre permear todo el corpus de lecturas a través de la discusión crítica.

El texto de Alejandra Hidalgo Rodríguez, titulado "Avances, observaciones y tareas pendientes: coloquio sobre transversalización de la perspectiva de género en la educación" se centra en la integración de la perspectiva de género desde un análisis muy general. Con lo anterior se muestra como los avances en cuanto a la aplicación de los Estudios de Género en la educación todavía son muy genéricos, pero poco a poco se van centrando en materias específicas; se evidencia que es una preocupación presente en la academia mexicana y se comienza a trabajar de forma más minuciosa. 
En cuanto al segundo hilo que guía la investigación, el canon de la literatura mexicana contemporánea estudiado desde la perspectiva de género, hay mucha más bibliografía, ya que la crítica feminista ha estado muy activa al respecto y ha propiciado la recuperación de muchas autoras mexicanas. Por ejemplo, el libro de Oswaldo Estrada Ser mujer y estar presente. Disidencias de género en la literatura mexicana contemporánea revisa la producción literaria de importantes autoras y su paso por la historia de la literatura en México. También hay varios artículos con un tema vinculado, por ejemplo, el ensayo titulado "El canon literario y las escritoras mexicanas. Entrevista a Luz Elena Gutiérrez de Velasco", en el que se hace una revisión de la situación actual del canon y la escritura de mujeres. Gracias a la cantidad de investigaciones relacionadas con la literatura femenina en México, se hace evidente que hay una preocupación al respecto y, sobre todo, que aún hay mucho trabajo por hacer.

La investigación en nuestro país sobre educación y género aún es incipiente, por lo tanto, para esta tesis parto de la premisa de que es necesario recurrir a los estudios elaborados en otros lugares. En Chile, por ejemplo, se ha desarrollado un gran número de textos que tienen como objetivo la integración de la perspectiva de género en la educación. Países como Gran Bretaña y Francia también tienen estudios serios dedicados a la incursión del discurso de género en la academia de manera formal. Por lo tanto, este trabajo parte de las premisas expuestas en algunos de estos textos y de las teorías que proponen para aproximarse al tema. Una vez establecidos los principios y conceptos necesarios, aplicaré las conclusiones teóricas para mostrar que se puede elaborar una integración entre los objetivos del programa y la propuesta de género. 


\section{Capítulo I. Los Estudios de Género}

\subsection{Los inicios de los Estudios de Género}

Como ya lo había enunciado, el primer paso para este trabajo es establecer los principios y conceptos que guiarán toda la reflexión sobre el programa, y las propuestas literarias concretas. En principio, es necesario abordar el campo de los Estudios de Género y determinar los parámetros adecuados de su estudio.

Se pueden definir los Estudios de Género como una metodología interdisciplinaria, ${ }^{6}$ que propone el cuestionamiento de los hechos sociales desde perspectivas históricamente consideradas periféricas. Los Estudios de Género echan mano de propuestas teóricas ya establecidas y, de manera simultánea, las cuestionan y utilizan para reelaborar los paradigmas de nuestra sociedad. Un ejemplo de dichos paradigmas, y quizá el más importante, es la división de la humanidad en "hombre” y “mujer”, cuyo sustento es la diferenciación biológica, principalmente la de los órganos genitales.

Este paradigma es importante porque rige una gran cantidad de actividades económicas y sociales, por ejemplo, la repartición del trabajo en el hogar, la idealización del comportamiento esperado de un hombre - que en teoría debe ser fuerte y cumplir con las funciones de protector y proveedor de la familia- y el papel asignado a la mujer como la cuidadora del hogar, de la familia quien necesita ser protegida o el de la damisela débil, en peligro, en espera de ser rescatada. Estos últimos perfiles han permeado el imaginario universal y pueden encontrarse desde los tradicionales cuentos para niños hasta en los modernos videojuegos. En función de estas imágenes se construye gran parte de la funcionalidad de nuestra sociedad.

\footnotetext{
${ }^{6}$ Rosa María González Jiménez, "Presentación. Estudios de Género en educación: una rápida mirada".
} 
En el campo económico y de la producción de bienes, muchas decisiones se sustentan en lo que se espera de cada uno de los sexos, por ejemplo, el tipo de producto, el diseño, el mercado al que se va a dirigir y hasta los colores. La construcción de la lengua tiene como una de sus principales características la división genérica que, cabe mencionar, es uno de los elementos más difíciles de explicar cuando se dan clases de inglés como lengua extranjera. Dado que el entendimiento de nuestra cotidianidad se rige por este paradigma, alterarlo, cuestionarlo o modificarlo es una tarea titánica, que poco a poco ha rendido frutos y ha logrado encontrar un lugar en las ciencias sociales como un nuevo tipo de enfoque que afecta varios aspectos de nuestras vidas. A lo largo de este texto, veremos que los Estudios de Género abarcan campos como la historia, la sociología, la literatura, la psicología, la geografía, la arqueología y la antropología, entre otros, y que así como toman premisas y metodologías de estas ciencias, las replantean para ampliar sus análisis e incluir a todos los miembros de la sociedad en su panorama de estudio.

Los Estudios de Género tienen sus orígenes en la escena estadounidense, especialmente en las ideas de la segunda ola ${ }^{7}$ de la crítica feminista, en el postestructuralismo, en el marxismo y en algunas de las teorías psicológicas freudianas. También hay una gran influencia de los movimientos sociales de mediados de los años 60 y principios de los 70: las protestas en contra de la guerra de Vietnam, la lucha por los derechos civiles de los afroamericanos, la lucha de los chicanos por mejores condiciones y derechos, y la lucha de los pueblos originarios. Todos estos movimientos generaron una verdadera revolución en la percepción del orden establecido que obligó a una reorganización de los actores sociales.

Uno de los cambios más significativos en cuanto al orden social fue el paso de lo privado a lo público; con esto me refiero a la lucha de las feministas por hacer que las experiencias de las

\footnotetext{
${ }^{7}$ Cf. Jane Pilcher e Imelda Whelehan, 50 Key Concepts in Gender Studies.
} 
mujeres, constreñidas al espacio del hogar y compartidas por muchas de ellas, salieran al ambiente público, que fueran debatidas y se convirtieran en parte de la discusión política. Una de estas experiencias comunes fue la violencia doméstica, que no se socializaba por vergüenza, pero que era -y es- un problema afín a muchas mujeres, quienes debido a los prejuicios no hacían nada y permanecían en una relación peligrosa.

En este mismo sentido, se reorganizaron los espacios públicos en función de la participación económica de las trabajadoras quienes ya no dependían del sustento masculino, lo cual atentaba contra la idea del proveedor, debido a su recién adoptada capacidad de ser proveedoras. Este fenómeno se inició en los años 40 como resultado de la gran cantidad de personal masculino que fue reclutado para la Segunda Guerra Mundial. No obstante, no será sino hasta 20 años después cuando las mujeres comenzaron a reclamar los derechos inherentes a su nueva posición en la sociedad, como elementos importantes en la cadena de producción, y que no les habían sido otorgados por la lentitud de cambio en la percepción general.

En esta misma línea, cabe mencionar una serie de reacciones sociales que formaban parte del contexto histórico durante el cual se da la resignificación del orden social, como el reposicionamiento de los afroamericanos, quienes, al igual que las mujeres, comenzaron a ocupar más espacios públicos y laborales; además, lograron que por ley se castigara cualquier acto de segregación. Otro ejemplo es el movimiento hippie, que utilizó espacios públicos para manifestarse y replanteó la organización familiar clásica, la práctica monogámica, la política bélica estadounidense, el origen de su riqueza y la fuente de su posición como potencia mundial; también cuestionó el sistema de producción capitalista y su relación con la naturaleza, aunque con menor impacto que la lucha por la igualdad racial. Por último, el movimiento chicano denunciaba las condiciones en las que trabajaban en los campos los migrantes, no sólo mexicanos, sino también 
asiáticos, centro y sudamericanos; a la vez que demandaba una mejor educación y el reconocimiento de los derechos de los hijos de migrantes mexicanos nacidos en Estados Unidos.

Todos estos movimientos tuvieron en común la lucha por sus derechos, entre los que se encontraba el uso del espacio público, como sinónimo de visibilización; y además iban en contra de un sistema económico, político y social que se beneficiaba de su posición inferior. Es justamente el cambio de la relación entre estos grupos, el sistema y la sociedad lo que la academia considera indispensable estudiar y, a la vez, profundizar en las consecuencias que tiene dicha reorganización.

Estudiar estos fenómenos y referirse a los grupos que los producen no fue considerado importante en sus inicios, por lo que también se tuvo que luchar por buscar un lugar en la academia y mostrar su importancia. En un principio, se organizaron grupos de trabajo que, con el tiempo y mucho esfuerzo, se convirtieron en los iniciadores de los departamentos dedicados a los estudios afroamericanos, chicanos y sobre los pueblos originarios del territorio estadounidense. Es aquí en donde surgen los Estudios de la Mujer, cuyo primer programa aprobado de manera oficial fue el de la Universidad de San Diego en $1970 .^{8}$

A partir de las investigaciones desarrolladas en este programa, se cuestionaron los términos “mujer” y "género", claves en la construcción de la crítica feminista y de los Estudios de Género. Es primordial recordar que dicha crítica estuvo determinada por los movimientos sociales de los años 60 ya mencionados y que, en conjunto, pusieron en evidencia lo diferente: se denunció que no todas las mujeres compartían el mismo estilo de vida, por lo tanto, se fueron integrando las experiencias de feministas afroamericanas, de países en vías de desarrollo y de mujeres no estadounidenses, blancas y de clase media. En esencia, lo que se hizo patente es la presencia del

\footnotetext{
${ }^{8}$ San Diego State University, Department of Women's Studies, College of Arts \& Letters. History, "Beginnings of a Women's Movement".
} 
"otro", es decir, se visibilizaron las diferentes realidades coexistentes de manera simultánea, no sólo las de las mujeres, sino las de todos los grupos que reclamaban sus derechos en esos momentos.

En congruencia con lo anterior, la crítica al término "género" derivó en el cuestionamiento de la construcción dicotómica que rige las relaciones de la sociedad, en el replanteamiento de la sexualidad y en la inclusión de todas las posibilidades biológicas y no biológicas presentes en la cotidianidad. Como resultado, surgió la necesidad de integrar a más actores a la discusión y de crear nuevos conceptos para referirse a las recién creadas estructuras de relación surgidas a partir de los estudios realizados con estas nuevas perspectivas. Poco a poco, el campo de estudio y las variables se fueron ampliando y finalmente devino en lo que hoy conocemos como Estudios de Género, cuyo primer programa de doctorado se aceptó en Estados Unidos en el 2005, en la Universidad de Indiana. ${ }^{9}$ Es cierto que el primer minor -lo que aquí conocemos como carrera técnica- en Estudios de Género se abrió varios años antes, durante la década de los 90, pero en la jerarquía académica de los EEUU -y creo que del mundo-, un campo de estudio recibe reconocimiento formal una vez que se abre un doctorado.

El movimiento en los Estados Unidos fue mucho más vigoroso que en otros lugares. Pensemos en el Reino Unido, cuyo movimiento sufragista fue avasallador durante el siglo XIX; no obstante, hubo un retroceso durante los años 80 y no fue sino hasta que la academia norteamericana, especialmente con la propuesta de revisión histórica de Joan Scott en los 90, planteó nuevas preguntas retomadas por los académicos en Inglaterra en donde se organizaron los primeros centros de investigación formal. En 1984 se fundó el Programa de Estudios sobre las mujeres en la Universidad de York y posteriormente Birbeck y Cambridge comenzaron un doctorado en Estudios de Género.

\footnotetext{
${ }^{9}$ Scott Jaschick, "Indiana Creates First Gender Studies PH.D."
} 
Este breve recuento deja en evidencia que los Estudios de Género son una disciplina joven cuyo desarrollo fue lento y tortuoso a lo largo de la segunda mitad del siglo XX. Tortuoso, pues fue una propuesta atacada desde distintos frentes, especialmente desde la esfera religiosa. Un ejemplo es la carta que se publicó en septiembre de 2011 en la página Diaconi, en la que Girolamo Furio, diácono de la Iglesia Católica, tilda la ideología de género de "doctrina pseudocientífica" que ataca la naturaleza, porque propone que la concepción de hombre y mujer es cultural y no natural. Una de las líneas de este texto muestra que el escritor está muy consciente de los alcances de la crítica de género, porque equipara la disociación del binomio hombre-mujer con la desaparición de la propiedad privada y las diferencias sociales: "Prima l'idea era di essereiguali se cancelliamo la proprietà privata, le differenze sociali, la meritocrazia, se cancelliamo tutto."10 Desde luego, el actual papa Francisco rechaza enfáticamente los Estudios de Género y ha dicho que son antimatrimonio y antinatura. ${ }^{11}$ Incluso, envió un documento en el que instruye a los líderes de la Iglesia católica a cuestionar fuertemente las ideas feministas que intentan borrar la diferencia entre hombres y mujeres. ${ }^{12}$

Finalmente, autores como David Patternot, quien escribe el texto "Christian Trouble: The Catholic Church and the Subversion of Gender”, y Elżbieta Korolczuk, investigadora de la Södertörn University en Suiza, coinciden en que la Iglesia ha creado un movimiento anti-Estudios de Género y que ha construido su propia terminología. Patternot explica: "Gender ideology', sometimes also called 'gender theory' does not designate the impressive amount of work by gender studies scholars in various fields and disciplines, but is a term created by the Catholic Church to

\footnotetext{
${ }^{10}$ Girolamo Furio, "L'ideologia del "gender": se la conosci la eviti”. Partiendo de la idea de ser iguales, cancelaríamos la propiedad privada, las diferencias sociales y la meritocracia, se cancelaria todo.

${ }^{11}$ John Newsome, "Pope warns of 'ideological colonization' in transgender teachings."

${ }^{12}$ John Hooper y Tania Branigan, "Pope warns feminists. Bishops told to take hard line on issue of gender".
} 
oppose women's and LGBT rights activism."13 En el mismo artículo, menciona que la Iglesia ha dado por llamar "terroristas intelectuales" a los académicos que son identificados con estas propuestas, especialmente a la filósofa Judith Butler.

Elżbieta realiza una reseña de un artículo de Sarah Bracke y David Patternott en donde se reúnen cinco textos que revisan diferentes aspectos de cómo se construye el discurso antigénero en la Iglesia en cuatro diferentes contextos: Argentina, Francia, Italia y Polonia. La autora asevera:

The contributors convincingly argue that even though the opposition against 'gender' can be attributed to many sources and engages different groups, including Protestant, Muslim as well as non-denominational actors, the development of anti-genderism has been driven mainly by the Vatican and informed by the Roman Catholic Church's key theological invention: the theory of the complementarity of the sexes. By tracing the development of anti-genderism as an ideological position and effective rhetorical device, the authors show how the anathematization of 'gender' emerged and spread through the world. ${ }^{14}$

Lo anterior demuestra no sólo una posición política en contra de los Estudios de Género, sino una movilización de la Iglesia para desacreditar las teorías y a quienes participan en este tipo de trabajos.

Asimismo, desde la academia hay quienes cuestionan la disciplina y la catalogan como adoctrinadora. Por ejemplo, el historiador Brian Palmer crítica la metodología y el enfoque,

\footnotetext{
${ }^{13}$ David Patternot, "Christian Trouble: The Catholic Church and the Subversion of Gender". Mantendré la lengua original de las citas y agregaré la traducción a pie de página. Todas las traducciones del inglés son mías, a menos que se indique lo contrario.

La 'ideología de género' también llamada 'teoría de género' no designa la impresionante cantidad de trabajo realizado por académicos especializados en Estudios de Género en diferentes campos y disciplinas, más bien son términos creados por la Iglesia Católica oponerse a los activistas que trabajan en favor de los derechos de las mujeres y de la comunidad LGBT..

${ }^{14}$ Elżbieta Korolczuk, "The Vatican and the Birth of Anti-Gender Studies". Los autores argumentan convincentemente que, aunque la oposición a los Estudios de Género puede ser atribuida a diversas fuentes y grupos incluyendo protestantes, musulmanes y actores individuales, el desarrollo de la corriente antigénero ha sido manejado principalmente por el Vaticano y alimentado por la filosofía clave de la Iglesia católica y romana: la complementariedad de los géneros. Los autores siguen desde su origen el desarrollo de la idea de antigénero como una posición ideológica y como una retórica condenatoria efectiva que logró esparcirse por todo el mundo.
} 
deslegitimando el replanteamiento del postestructuralismo, uno de sus soportes teóricos. ${ }^{15}$ Desde la misma escuela feminista existen detractores, quienes consideran que los Estudios de Género podrían llegar a invisibilizar a la mujer en el estudio de "las relaciones entre masculinidades u hombre/mujer."16

El ataque a los Estudios de Género también ha sido titular de los periódicos, revistas y otros medios impresos, donde se utilizan ideas concebidas en el marco de los Estudios de Género en contra de éstos creando un efecto de refracción. Un ejemplo es la discusión, publicada en el diario inglés The Guardian, en la que un alumno demanda al Instituto de Género de la Escuela de Economía de Londres y se declara víctima de discriminación masculina. ${ }^{17}$ Esto quiere decir que en los ambientes feministas o de Estudios de Género se relega a los hombres por serlo y no se toman en cuenta sus posturas; en otras palabras, se privilegia a las mujeres. Es como si en estos espacios la discriminación que se estudia y denuncia se aplicara de forma inversa. Los miembros masculinos del departamento en cuestión aseguraron que en ningún momento se han sentido discriminados, sin embargo, este es un claro ejemplo de desacreditación por medio de la victimización.

La victimización por parte del género masculino es una herramienta utilizada en las relaciones cotidianas para descalificar las posturas feministas. Su funcionamiento tiene sus orígenes en el proceso de visibilización y denuncia de los problemas que, durante siglos, se han considerado exclusivos de las mujeres: la violencia de género, en sus distintos grados, la violencia doméstica, el cuidado de la familia y los enfermos, entre muchos otros. Una vez que estos actos sociales se reconocen como actitudes que afectan a las mujeres y ellas se convierten en víctimas,

\footnotetext{
${ }^{15}$ Jean-ChristopheAgnew, "Review on Descent into Discourse. The Reification of Language and the Writing of Social History by Bryan D. Palmer".

${ }^{16}$ Jane Pilcher and Imelda Whelehan, 50 Key Concepts in Gender Studies, p. 13.

${ }^{17}$ Tom Martin, "Youcan't deny it. Gender studies is full of male-blaming bias".
} 
el victimario busca disminuir la validez de las denuncias tratando de ponerse en una posición en la que él también es víctima, al menos en el discurso.

Este tipo de defensa discursiva se ha hecho más evidente en las redes sociales, donde los ataques a feministas son despiadados y los comentarios de hombres "discriminados" abundan, sin pensar que muchas veces sus quejas son producto del mismo sistema que les brinda una posición privilegiada.

Un ejemplo de la victimización de los hombres es el tipo de memes surgidos a partir del movimiento internacional \#Metoo que consiste en una denuncia a través de la red social de una situación de acoso. La cantidad de denuncias fue abrumadora y como consecuencia se hizo evidente que no importa la clase social, el nivel educativo, el país de residencia, la raza o la actividad económica que realicen las mujeres; de igual manera sufren acoso. Esta movilización tuvo un impacto global y llevó al cuestionamiento de actitudes o acciones realizadas de manera cotidiana consideradas inocentes o aceptadas, como el muy mexicano piropo.

Es así cómo muchas personas comienzan a jugar con la ironía y con estereotipos para burlarse de legítimos problemas femeninos y ponerse en la posición de discriminados, victimizados y abusados como se aprecia en el siguiente meme.

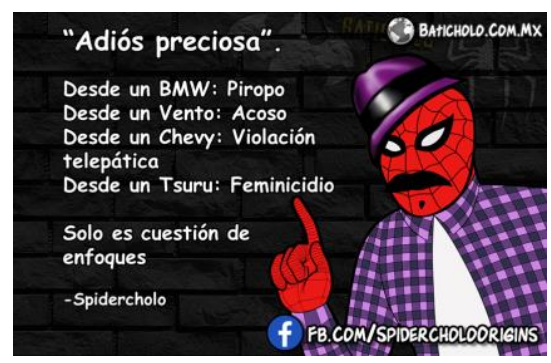

En esta imagen vemos que se parte de un piropo y se hace una gradación de la violencia de género de menor a mayor mediante un paralelismo con autos de diferentes marcas, ubicando el auto más caro en relación con el menor nivel de violencia BMW, piropo, y el más barato, Tsuru, con el 
mayor nivel de violencia, feminicidio, y remata diciendo que todo es cuestión de enfoque. El resultado es que se desestima cualquier tipo de violencia y se sugiere que la perspectiva de la denunciante depende de la posición económica del acosador. Este tipo de mensaje se ha extendido en las redes y se ha convertido en un chiste que, en mi opinión, funciona como normalizador de la violencia; con esto me refiero a que se repite tanto que se hace común y deja de ser visible, con lo que el problema original se diluye.

Si bien los Estudios de Género son una disciplina en constante escrutinio social y académico, no podemos dejar de reconocer su importancia en los diferentes campos que han aceptado sus propuestas dando forma a nuevas relaciones sociales y a políticas públicas, desprendidas del Consejo Europeo y de la ONU, las cuales han visibilizado el sistema patriarcal regidor de la sociedad y han manifestado la necesidad de modificarlo. En este caso, la ONU ha trabajado sobre políticas de género desde hace más de 50 años y ha sido guía para otros organismos, como la Unión Europea. En una publicación del Programa de las Naciones Unidas para el Desarrollo, de 2008, se hace una revisión de la “evolución de la atención brindada por los gobiernos a las necesidades, intereses y asuntos de las mujeres" y se presentan en una tabla que reproduzco a continuación:

Tabla 1

Fases evolutivas del reconocimiento de los derechos de las mujeres en la ONU

\begin{tabular}{|c|c|c|c|}
\hline $\begin{array}{c}\text { Fases } \\
\text { evolutivas }\end{array}$ & Hechos influyentes & Foco de interés de la etapa & $\begin{array}{l}\text { Acciones más } \\
\text { comunes }\end{array}$ \\
\hline $\begin{array}{l}\text { Primera fase } \\
1945-1962\end{array}$ & $\begin{array}{l}\text { - Creación de la comisión de la } \\
\text { Condición jurídica y social de la } \\
\text { Mujer (Comission for the status of } \\
\text { woman) } \\
\text { - Adopción de la Declaración } \\
\text { Universal de los Derechos } \\
\text { Humanos }\end{array}$ & $\begin{array}{l}\text { Interés centrado en señalar las } \\
\text { desigualdades y en determinar } \\
\text { los obstáculos al logro de la } \\
\text { igualdad }\end{array}$ & $\begin{array}{l}\text { Acciones } \\
\text { orientadas, casi } \\
\text { exclusivamente, } \\
\text { a lograr igualdad } \\
\text { jurídica }\end{array}$ \\
\hline $\begin{array}{l}\text { Segunda fase } \\
1963-1975\end{array}$ & $\begin{array}{l}\text { - Aprobación de la Declaración sobre } \\
\text { la Eliminación de la Discriminación } \\
\text { contra la Mujer }\end{array}$ & $\begin{array}{l}\text { El derecho de las mujeres a } \\
\text { disfrutar de los beneficios del } \\
\text { desarrollo y a ser integradas al } \\
\text { proceso como una condición }\end{array}$ & $\begin{array}{ll}\text { - Inicio } & \text { de } \\
\text { respuestas } & \\
\text { oficiales } & \mathrm{a} \\
\text { demandas } & \text { de }\end{array}$ \\
\hline
\end{tabular}




\begin{tabular}{|c|c|c|c|}
\hline & $\begin{array}{l}\text { - Aparece el documento "Estrategia } \\
\text { de Desarrollo internacional para la } \\
\text { Segunda Década (1971-1980)", } \\
\text { donde se habla de la necesidad de la } \\
\text { "plena integración de las mujeres al } \\
\text { esfuerzo total del desarrollo" } \\
\text { - Celebración de la Primera } \\
\text { Conferencia Mundial del Año } \\
\text { internacional de la Mujer, en } \\
\text { México }\end{array}$ & $\begin{array}{l}\text { para el logro de las metas del } \\
\text { desarrollo y la paz duradera }\end{array}$ & $\begin{array}{l}\text { igualdad } \\
\text { jurídica } \\
\text { - Primeros } \\
\text { ensayos sobre } \\
\text { la formulación } \\
\text { de políticas } \\
\text { dirigidas a las } \\
\text { mujeres } \\
\text { - Cambios de } \\
\text { actitudes y } \\
\text { compromisos } \\
\text { políticos de los } \\
\text { gobiernos en } \\
\text { relación con las } \\
\text { mujeres. } \\
\text { Creación de las } \\
\text { primeras } \\
\text { estructuras } \\
\text { institucionales } \\
\text { muy } \\
\text { preliminares }\end{array}$ \\
\hline $\begin{array}{l}\text { Tercera fase } \\
1976 \text { a } 1985\end{array}$ & $\begin{array}{l}\text { - Primera Década de ONU hacia la } \\
\text { Mujer, en el marco de la Estrategia } \\
\text { Internacional para el Desarrollo } \\
\text { - Segunda Conferencia Mundial de la } \\
\text { Mujer en Copenhague, } 1980 \\
\text { - Adopción de la Convención para la } \\
\text { Eliminación de toda Forma de } \\
\text { Discriminación contra la Mujer } \\
1979 \\
\text { - Tercera Conferencia Mundial de la } \\
\text { Mujer, Nairobi, } 1985\end{array}$ & $\begin{array}{l}\text { - Cambio en la conciencia } \\
\text { internacional sobre el impacto } \\
\text { de la situación de la mujer en } \\
\text { el desarrollo, especialmente a } \\
\text { través de fenómenos } \\
\text { generalizados como la } \\
\text { pobreza, la superpoblación el } \\
\text { analfabetismo, la desnutrición } \\
\text { y otros semejantes } \\
\text { - Nueva concepción de la mujer } \\
\text { como "agente beneficiaria del } \\
\text { proceso de desarrollo en todos } \\
\text { los sectores y todos los } \\
\text { niveles" }\end{array}$ & $\begin{array}{l}\text { Programas } \\
\text { dirigidos } \\
\text { mujeres a } \\
\text { sectores } \\
\text { desventaja para } \\
\text { fortalecer sus } \\
\text { capacidades } \\
\text { económicas } \\
\text { productivas y } \\
\text { elevar } \\
\text { capacidades } \\
\text { sociales básicas } \\
\text { Fortalecimiento } \\
\text { progresivo de la } \\
\text { institucionalidad } \\
\text { a cargo de los } \\
\text { asuntos de las } \\
\text { mujeres }\end{array}$ \\
\hline $\begin{array}{l}\text { Cuarta fase } \\
1985 \text { a } 1995\end{array}$ & $\begin{array}{l}\text { - IV Conferencia Mundial en Beijing } \\
\text { - Conferencias Mundiales sobre } \\
\text { Ambiente, Derechos Humanos, del } \\
\text { Niño y la Niña, Población, } \\
\text { Asentamientos Humanos; Cumbre } \\
\text { social }\end{array}$ & $\begin{array}{l}\text { - Evaluación de los impactos de } \\
\text { los esfuerzos realizados } \\
\text { - Consideración del carácter } \\
\text { global que deben tener } \\
\text { - Aparecen el enfoque de género } \\
\text { y el principio del } \\
\text { mainstreaming. } \\
\text { - Relevancia del tema de la } \\
\text { violencia }\end{array}$ & $\begin{array}{l}\text { - Fortalecimiento } \\
\text { de organismos de } \\
\text { las mujeres } \\
\text { - Políticas } \\
\text { públicas } \\
\text { sectoriales con } \\
\text { atención en los } \\
\text { asuntos de las } \\
\text { mujeres } \\
\text { - Primeros planes }\end{array}$ \\
\hline
\end{tabular}


En la tabla anterior es posible ver cómo los cambios políticos se dieron en coordinación con los avances en la academia y con los movimientos sociales, que son en realidad los que pueden modificar la percepción cultural.

La primera etapa en la que se destaca la firma de la Declaración de los Derechos Humanos y la conformación de una comisión exclusiva para el estatus de la mujer se establece después de que varios países como Nueva Zelanda, en 1881, y Estados Unidos, en 1869, dotaron a las mujeres de cierto reconocimiento jurídico en algunos sectores sociales y brindado espacios a algunos movimientos protofeministas, ${ }^{18}$ como "la primera convención sobre los derechos de la mujer en Estados Unidos, organizada por Lucretia Mott y Elizabeth Cady Stanton", ${ }^{19}$ en Seneca Falls, en 1848, en donde se hace la declaración de "Seneca Falls" que denuncia las desventajas políticas que enfrentaban las mujeres, "empleando el vocabulario político de la Declaración de Independencia de los Estados Unidos." 20 Por otra parte, el movimiento sufragista en Gran Bretaña tiene sus principios en 1868, con el primer encuentro público que se refería al derecho al voto de la mujer en Manchester.

En la década que corresponde a la primera etapa, vemos que la mayoría de los países miembros concede el voto a la mujer y la dota de capacidades jurídicas establecidas en los artículos 6 y 21 de la Declaración Universal de los Derechos Humanos. ${ }^{21}$

\footnotetext{
${ }^{18}$ Nattie Golubov, La crítica literaria feminista. Una introducción práctica, p. 9. La autora, utiliza el término protofeminista para referirse a los movimientos previos a la invención del término "feminista" que ella misma explica fue utilizado por primera vez "a finales del siglo XIX por la sufragista [francesa] Hubertine Auclert para describirse a sí misma."

${ }^{19}$ Ibid., p. 12.

${ }^{20}$ loc. cit.

${ }^{21}$ Naciones Unidas. Declaración Universal de Derechos Humanos.
} 


\section{Año de aprobación sufragio femenino}

2040

2020

2000

1980

1960

1940

1920

1900

1880

1860

1840

1820

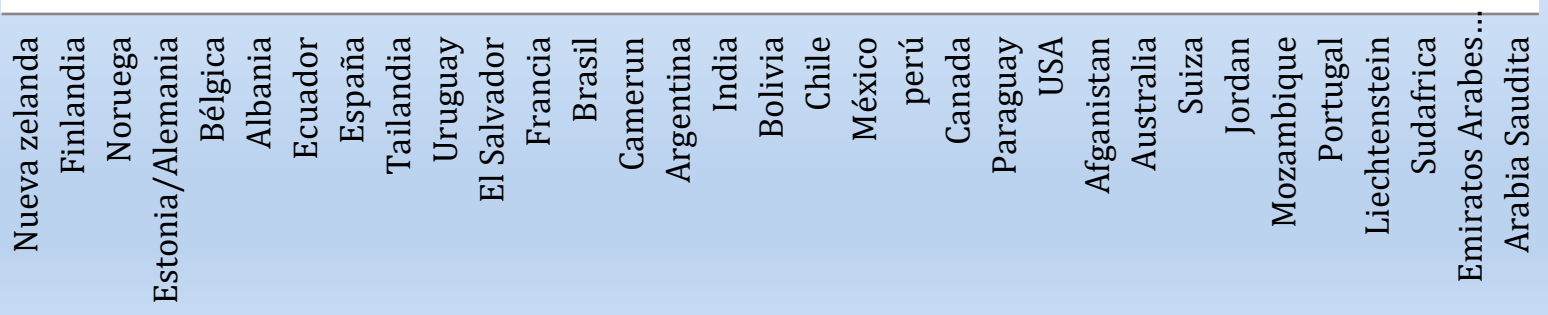

$\Leftrightarrow$ Año de aprobación sufragio femenino

La segunda etapa coincide con los movimientos sociales y con la formación de los primeros centros de investigación sobre género y las mujeres; mientras que en la tercera fase se consolidan los Estudios de Género como una disciplina con programas como el de Estudios Sobre la Mujer de la Universidad de York en Reino Unido en 1984. En la cuarta fase, ya se menciona de manera específica el concepto de Enfoque de Género en el Desarrollo o por sus siglas (GED) y se explica que:

Los desarrollos conceptuales que dieron perfil al enfoque GED, fueron principalmente: el sistema de relaciones de poder entre los géneros, continuidad/discontinuidad genérica de los espacios público y privado, el triple rol de las mujeres, la diferencia entre situación y posición de las mujeres, lo referido a intereses y necesidades prácticas y estratégicas, la división de trabajo por géneros, el empleo diferenciado del tiempo en hombres y mujeres, el acceso y los controles diferenciados sobre ingresos y recursos, la esencialidad del empoderamiento para revertir la asimetría, entre otros. Gracias a estas concepciones convertidas en herramientas para comprender la realidad y otras más afinadas, se desarrollaron importantes paradigmas de análisis de género que han ampliado la 
comprensión de la realidad de las relaciones entre hombres y mujeres y han apuntalado las propuestas en materia de políticas públicas hacia el objetivo de igualdad de géneros. ${ }^{22}$

Para 2015, las propuestas de género llegaron a ser tan específicas que en el informe She Figures 2015 de la Comisión Europea para la investigación e innovación se hace un estudio enfocado en los avances logrados en busca de la igualdad de género en Europa, y se presenta una serie de estadísticas en las que se puede ver una comparación entre hombres y mujeres en programas de doctorado y en centros de investigación. Aquí ya existe una relación directa de las políticas de género con la educación. ${ }^{23}$

Hasta este momento, había tenido el cuidado de no utilizar el término patriarcal más allá de lo estrictamente necesario, ya que, como hemos visto, los Estudios de Género trabajan con paradigmas que generan conflicto y, en mi experiencia, en cuanto se menciona dicho término hay percepciones que ponen una barrera y hacen más difícil avanzar en la discusión de cualquier tema. No obstante, se hace indispensable utilizarlo para comprender muchas de las premisas de los Estudios de Género. Así como el término patriarcado, otras palabras han sido creadas o resignificadas para acoplarse a las necesidades de la perspectiva de género, por lo que se hace necesario mencionar algunas de ellas. Debo señalar que el orden en el que presento mis términos clave responde a las necesidades de la propuesta didáctica y no a una cuestión de jerarquía, aunque no podemos dejar de lado que estoy trabajando desde la perspectiva de una mujer heterosexual, mestiza de piel blanca, de una clase social con acceso a educación superior y tecnología, y que en las definiciones tomadas de diferentes textos incluiré mi experiencia.

\footnotetext{
${ }^{22}$ Prince García, Políticas de Igualdad, Equidad y Gender Mainstreaming ¿De qué estamos hablando?: Marco Conceptual, p. 14.

${ }^{23}$ European Commision. She Figures 2015.
} 
El primer término a definir es, justamente, el de patriarcado y se debe a su constante aparición en las mismas definiciones y a la gran variedad de usos con los que cuenta, a las posibles confusiones y, sobre todo, a la resistencia que genera su sola mención. En el diccionario de la RAE se define como el sistema de organización familiar en el que el eje rector es el padre. También se llama así al territorio dirigido por un patriarca, y, de manera general, todas las acepciones se refieren a la "organización social primitiva en que la autoridad es ejercida por un varón, jefe de cada familia, extendiéndose este poder a los parientes aun lejanos de un mismo linaje."24

Los Estudios de Género retoman las propuestas feministas que definen el patriarcado como el sistema opresor rector de las relaciones entre hombres y mujeres. No obstante, existe una seria discusión respecto al uso del término debido a la convivencia de cuatro corrientes feministas que lo definen: las radicales, las liberales, las marxistas y las del sistema dual. Es importante mencionar las distintas corrientes del feminismo y su interpretación para comprender que el término no es inmutable, que ha pasado por varios momentos, y, sobre todo, para trazar la complejidad del proceso de resignificación de elementos existentes a través de nuevas perspectivas y que, de forma casi natural, partes de todas las visiones confluyen en un mismo punto.

Las teorías feministas radicales consideran que el sistema patriarcal es independiente de cualquier otro sistema de dominación social. Es decir, se hace un análisis ahistórico de éste, por lo tanto, el capitalismo y el racismo son considerados de forma individual y no en conjunción con el patriarcado, como si éste no jugara un papel decisivo en cuestiones políticas, económicas y sociales. En otras palabras, es como si el sistema de organización social dual no tuviera un papel preponderante en la construcción de la cultura y como si siempre estuviera al margen de las situaciones sociales que lo enmarcan.

\footnotetext{
${ }^{24}$ Diccionario de la Real Academia On line.
} 
Muchos de los conceptos que retoman los Estudios de Género provienen de esta corriente del feminismo: la observación crítica de aspectos cotidianos y su identificación como parte del sistema de dominación. Un ejemplo es cuestionar quién hace el trabajo del hogar y quién interrumpe a quién en una conversación. El slogan de esta corriente es "the personal is political" y, para estas feministas, la familia es entendida como el principal medio de dominación de la mujer. La principal crítica a este tipo de feminismo es su ahistoricidad y la importancia que tienen las cuestiones biológicas en las interpretaciones.

La corriente liberal del feminismo no entiende la dominación como un sistema complejo, sino más bien como la suma de pequeñas privaciones que van a enajenar a las mujeres de la vida pública. Las feministas que siguen esta línea consideran que la falta de educación, la diferencia en cuanto al tipo de empleos y al salario, son elementos independientes que generan discriminación. Al feminismo liberal se le critica por la incapacidad de trabajar con las bases histórico-sociales de la inequidad de género.

El feminismo marxista es lo opuesto al feminismo radical, que considera que el patriarcado es una derivación del capitalismo y que utiliza la dominación para aprovecharse del trabajo femenino. Este tipo de crítica no puede lidiar con la inequidad de género en momentos previos o posteriores al capitalismo, por lo que se le considera reduccionista.

Por último, la teoría del sistema dual mezcla ideas de las propuestas previas y las fusiona, ya que en todas hay elementos teóricos valiosos que no se contraponen entre sí. Si bien estas cuatro son las principales líneas del feminismo, es importante mencionar que no son las únicas, y dado que los Estudios de Género retoman propuestas de varias corrientes, es muy probable que encontremos mezclas de estos discursos en diferentes trabajos de investigación. ${ }^{25}$

\footnotetext{
${ }^{25}$ Todas las definiciones de las teorías fueron tomadas del texto Theorizing Patriarchy de Sylvia Walby.
} 
Para esta tesis, utilizaré la propuesta de Sylvia Walby, socióloga y profesora de la Universidad de Lancaster, quien dice que "Patriarchyis a system of social structures and practices in which men dominate, oppress and exploit women". ${ }^{26}$ Walby agrega a su definición seis categorías o estructuras del patriarcado: "Household production, paid work, the state, male violence, sexuality, culture."${ }^{\prime 27}$ Es importante mencionar las divisiones que propone, reconocerlas y entenderlas, porque en el proceso de lectura son elementos identificables que pueden ser un detonante para la reflexión sobre la perspectiva de género en el salón de clases.

En conjunción con los elementos del patriarcado, es necesario regresar al término género que, como ya lo comenté, es parte de una intensa discusión, no sólo en el ámbito académico, sino en la sociedad en general. La palabra género viene del latín genus que quiere decir categoría, referente a lo natural. En los años 70 se comienza a utilizar para hablar de las diferencias biológicas entre los sexos: "It was used as an analytical category to draw a line of demarcation between biological sex differences and the way these are used to inform behaviors and competencies, which are assigned as either 'masculine' or 'feminine'."'28

En esta investigación utilizaré la palabra género para referirme a las prácticas sociales y comportamientos de un ser humano, sin importar que sea etiquetado como hombre o mujer, de acuerdo a las características físicas evidentes de su anatomía. Sin embargo, no puedo dejar de mencionar algunos de los conflictos del uso de esta categoría. En el texto "El delito del cuerpo", Meri Torras, profesora de la Universidad Autónoma de Madrid, explora las complejidades del cuerpo en su relación con los estudios feministas y dice:

\footnotetext{
${ }^{26}$ Jane Pilcher e Imelda Whelehan. 50 Key Concepts in Gender Studies, p. 94. El patriarcado es un sistema de prácticas y estructuras sociales en el que los hombres dominan, explotan y oprimen a la mujer.

${ }^{27}$ Sylvia Walby, Theorizing Patriarchy. p. 57. Trabajo doméstico, trabajo remunerado, el estado, violencia de género, sexualidad y cultura.

${ }^{28} \mathrm{Ibid}$., p.58. El término era utilizado como una categoría analítica para marcar una línea entre las diferencias biológicas de los sexos y la forma en que éstas se relacionan con comportamientos sociales y competencias a las que se les clasifica como masculinas o femeninas.
} 
Dentro de las propuestas del feminismo se estableció la diferencia entre sexo y género a fin de evitar el biologismo del cuerpo - justamente por lo que tenía de evidente y explícito. De este modo, se entendía el sexo como natural, previo, esencial y biológico, frente al género que se consideraba cultural, posterior, un constructo social. La frase de Simone de Beauvoir -"Una no nace mujer, se convierte en mujer"- puede ser interpretada en esta línea. ${ }^{29}$

Una de las primeras complicaciones que veo en el uso de la definición, especialmente en el ámbito escolar, es el alejamiento del biologismo, línea positivista que rige los conocimientos de los estudiantes desde el principio de su vida tanto académica como social. Este acercamiento es la enseñanza generalizada de que la diferencia de los sexos se basa únicamente en las características de sus genitales y se les dice a los niños desde que están en casa-si hay suerte- que los niños tienen pene y las niñas, vagina. Esta explicación se retoma en la escuela y queda siempre sesgada debido a que en ningún momento se hace referencia a la posibilidad de tener algún tipo de desarrollo diferente, que es el espacio en donde se podría mencionar a las personas a las que antes se les denominaba hermafroditas y que ahora conocemos como intergénero. El biologismo no solo se ocupa de las características físicas, sino que atribuye a la fisiología elementos actitudinales, es decir, la forma de ser se define por los genitales.

Marta Lamas, en su curso “¿De qué hablamos cuando hablamos de género?”, utiliza el término habitus ${ }^{30}$ para referirse a las prácticas y costumbres culturales que pasan de generación en generación sin cuestionarse y dictan los "mandatos de género". Estos últimos son las creencias culturales de lo que es un hombre y una mujer, y, asimismo, determinan el comportamiento aceptado de cada uno de los miembros de una comunidad específica. Esto quiere decir que los

\footnotetext{
${ }^{29}$ Meri Torras, "El delito del cuerpo", p. 14.

${ }^{30} \mathrm{El}$ concepto de Habitus que utiliza Marta Lamas y que se retoma en este trabajo proviene de la propuesta sociológica de Pierre Bordieu. "Estrategias de reproducción y modos de dominación".
} 
mandatos de género no son universales y dependen del momento histórico, político y social de cada cultura.

Para lograr introducir el concepto de género en la esfera escolar es necesario explicar la construcción mental y corporal de los seres humanos y la posibilidad de que sexo y género no sean congruentes. También sería necesario mencionar la existencia de más posibilidades de relación, no sólo el binomio hombre-mujer, sino que matemáticamente hay al menos dos tipos más de relación (hombre-hombre, mujer-mujer), y agregar que las características femeninas y masculinas son una simbolización. Es decir, el comportamiento esperado de un hombre o de una mujer depende del espacio geográfico y del momento histórico en el cual cada uno de nosotros se encuentre; por lo tanto, no es estático sino mutable y es necesario revisar todas las posibilidades existentes en nuestro territorio nacional para incluir a todos los habitantes del país.

Como consecuencia de la acepción del término "género", se hace necesario hablar de la identidad de género, que para Judith Butler es la forma en la que actuamos; por lo tanto, no es más que el efecto de una serie de prácticas institucionalizadas y discursos que no tienen un origen determinado, ${ }^{31}$ sino que son como una actuación. En el Diccionario de estudios culturales latinoamericanos se da una explicación más precisa de la propuesta de Butler, en la que se destaca el carácter performativo de la identidad de género:

Butler, al releer la actuación del travesti, identificó una articulación plenamente artificial del género por la que definió la identidad de género (masculinidad/feminidad) no como aspecto esencial o biológico del sujeto, ni tampoco como mera construcción ideológica absorbida a través de la educación, sino como un performance, es decir, una actuación aprendida a nivel subconsciente o realizada conscientemente por parte del sujeto. Este aspecto performativo de género también llamó mucha atención ya que rompió con los

\footnotetext{
31 Judith Buttler, Gender in Trouble Feminism and the Subversion of Identity.
} 
debates eternos del determinismo contra el constructivismo, lo cual tenía implicaciones importantes para la política de la identidad. ${ }^{32}$

Entendamos el asunto de la performatividad como la manera de actuar, las actitudes de todos los días y la forma en que nos desenvolvemos en los distintos espacios en los que participamos.

Para finalizar con la definición de identidad de género, mencionaré la que publica la Secretaría de Gobernación de México en su blog dedicado al tema de la discriminación, para exponer la postura oficial del Gobierno mexicano:

La identidad de género es el concepto que se tiene de uno mismo como ser sexual y de los sentimientos que esto conlleva; se relaciona con cómo vivimos y sentimos nuestro cuerpo desde la experiencia personal y cómo lo llevamos al ámbito público, es decir, con el resto de las personas. Se trata de la forma individual e interna de vivir el género, la cual podría o no corresponder con el sexo con el que nacimos. ${ }^{33}$

La postura de la SEGOB coincide con las propuestas de los Estudios de Género que, como ya hemos visto, se establecen desde organismos internacionales. Se acepta públicamente que la identidad de género se refiere a la experiencia individual, es decir, a la forma en la que cada uno se ve o se entiende a sí mismo independientemente de su sexo o de cómo lo expresa en su entorno.

El uso del género en este sentido y la disolución del binomio hombre-mujer han tenido consecuencias importantes en la sociedad: no sólo en la visibilización de las diferentes identidades de género, sino también en las políticas públicas y la jurisprudencia. Por ejemplo, la aceptación de distintos géneros obliga a reconocer la unión entre personas del mismo sexo de manera legal. Siguiendo la línea de las políticas y su influencia en la vida cotidiana, es necesario referirse al término Gendermainstreaming. En el texto de la conferencia de Pekín de 1995, que se menciona en la Tabla 1, se establece el término Gendermainstreaming, el cual implica una serie de estrategias

\footnotetext{
${ }^{32}$ Mónica Szurmuck y Robert Mckee, Diccionario de estudios culturales latinoamericanos.

${ }^{33}$ Secretaría de Gobernación, ¿Qué es la identidad de género?
} 
cuyo objetivo es lograr la equidad de género en distintos campos. La traducción del término al español crea controversia, ya que hay dos traducciones diferentes. La primera se propone en el artículo "La perspectiva de género en los sistemas de evaluación de la producción científica", de Catalina Lara, profesora del departamento de Bioquímica Vegetal y Biología Molecular de la Universidad de Sevilla, quien traduce el término como "Integración de género"; y la segunda interpretación se encuentra en el artículo "El mainstreaming de género en la Unión Europea", de Emanuela Lombardo, quien además de citar al grupo de expertos del Consejo de Europa, que define el mainstreaming como "[...] la organización (la reorganización), la mejora, el desarrollo y la evaluación de los procesos políticos, de modo que una perspectiva de género se incorpore en todas las políticas, a todos los niveles y en todas las etapas, por los actores normalmente involucrados en la adopción de medidas políticas."; 34 traduce el término como "transversalidad".

En mi investigación retomaré la segunda definición, porque me parece que será más sencillo entender gendermainstreaming como políticas de integración de género y utilizar transversalidad como el proceso mediante el cual se insertan estas políticas en diferentes campos, especialmente en la educación. Para mí, la transversalidad será el cruce de las propuestas de género a lo largo del currículum escolar con el fin de trazar una línea que atraviese varias materias. Es cierto que ambas acepciones se relacionan y que pueden ser confusas. No obstante, en el nuevo modelo educativo, transversalidad se entiende como:

Noción que se refiere a un conjunto de conocimientos o habilidades que se hacen presentes en distintos ámbitos y momentos del currículo, como la lectura, la escritura, o el cálculo; y en el plano de la formación, la Educación Socioemocional que refuerza y es reforzada por otras áreas de conocimiento. ${ }^{35}$

\footnotetext{
${ }^{34}$ Emanuela Lombardo, "El mainstreaming de género en la Unión Europea".

${ }^{35}$ Secretaría de Educación Pública, Aprendizajes Clave para la Educación Integral.
} 
Así, entendamos la transversalidad como el punto de encuentro de una materia con alguna otra en el currículum. Por ejemplo, en el programa de Inglés de segundo de secundaria, se contempla un módulo dedicado a los desastres naturales; utilizando este tema se puede dar la transversalización del conocimiento con biología o geografía, y al mismo tiempo incluir el valor de la solidaridad. Por esta razón utilizaré políticas de integración de género cuando sea necesario referirse a gendermainstreaming.

Finalmente, quiero señalar que según el documento "Gender and Excellence in the Making" de la Comisión Europea para la Investigación, de 2004, los principios de las políticas de integración de género en las instituciones científicas son:

- building equality into culture and organizations;

- treating employees as whole persons;

- respect and human dignity (anti-discrimination);

- participation and consultation,

- and visioning. ${ }^{36}$

En estas directrices, notamos cómo poco a poco se van moviendo los objetivos y ya no sólo es la integración de las mujeres, sino que ya se habla de forma general de todos los seres humanos sin distinción de género, lo que me lleva a cuestionar el uso del genérico masculino en español para referirse a todas las personas, o el uso del masculino y femenino en la misma oración, o la integración de las letras x o e como neutras. Dado que es un tema álgido y complicado, procuraré utilizar las palabras "seres humanos" y "humanidad" cuando quiera referirme a la generalidad occidental y, de ser necesario, mantendré el genérico masculino por convención.

\footnotetext{
${ }^{36}$ European Commission, Gender and Excellence in the Making. La construcción de equidad tanto en las organizaciones como en la cultura. El trato a los empleados como seres integrales. Respeto y dignidad humana (antidiscriminación). Participación, consenso y planeación.
} 
Una de las prioridades de las políticas de integración de género es romper con el techo de cristal y permitir el avance de las mujeres en paridad con los hombres. La expresión techo de cristal, Glass Ceiling, es utilizada para referirse a la multiplicidad de factores perjudiciales al avance de las mujeres, pero que son invisibles debido a su inserción en las prácticas sociales cotidianas. Un ejemplo de esto es la discriminación por género que se puede dar en los departamentos de recursos humanos sin ser reconocida como tal.

El Consejo Europeo llevó a cabo un estudio en instituciones de educación superior y encontró que la discriminación de género se da de manera automática y se otorgan más apoyos a hombres que a mujeres; se considera que las mujeres son de riesgo debido a la posibilidad de ser madres y como consecuencia los proyectos quedarían inconclusos; no obstante, ésta no es una consideración consciente, no se menciona y simplemente se asume como una posibilidad. A todo este tipo de obstáculos se le llama techo de cristal.

Éstos son algunos de los elementos fundamentales para la comprensión de las propuestas de los Estudios de Género. La gran diversidad de términos y elementos que se conjugan dan una idea de la cantidad de materias y problemas que se entrecruzan cuando se trabaja este tipo de perspectiva; también nos permiten entender por qué es un enfoque tan controvertido. Como hemos visto, los Estudios de Género se han insertado en la academia de forma lenta, pero con paso firme y han conseguido ser una herramienta para la investigación social.

\subsection{Los Estudios de Género en México}

En México no es diferente. Los Estudios de Género surgen de los intereses de las mujeres y como resultado de los movimientos feministas. En el artículo "Madres simbólicas del feminismo en México", Graciela Hierro hace un recorrido histórico nombrando a algunas de las feministas más influyentes de la historia. Comienza por Simone de Beauvoir y Virginia Woolf, como predecesoras 
internacionales, y a Sor Juana Inés de la Cruz y a Rosario Castellanos como las precursoras del feminismo en México. Ya en el siglo XX, se refiere a "Alaíde Foppa, quien es la iniciadora de los estudios feministas en la UNAM y creadora de la revista Fem junto con la doctora Vera Yamini. ${ }^{37}$ Graciela Hierro habla de sus contemporáneas, ya que todas forman parte del Programa Universitario de Estudios de Género, uno de los pioneros de esta disciplina en México: “Teresita de Barbieri, Gloria Careaga, Francesca Gargallo, Marcela Lagarde, Gabriela Cano, Griselda Gutiérrez, Lorenia Parada, Olga Bustos, Gabriela Delgado." 38 Sostiene que Rosario Castellanos abre el camino del feminismo en México en su tesis de maestría, en cuya primera línea aparece la pregunta: “¿Existe una cultura femenina?”, y a partir de ahí elabora una serie de reflexiones en las que llega a la conclusión de que las mujeres básicamente han estado excluidas del mundo de la cultura, punto coincidente con Simone de Beauvoir. Hierro supone que Castellanos no leyó a Beauvoir, por la fecha de edición de la tesis, con esto se entiende que ambas autoras llegan a la misma conclusión pese a encontrarse en circunstancias diferentes; esta coincidencia permite entrever la universalidad de la situación femenina. Finalmente, concluye señalando la tesis de Rosario Castellanos como un ejercicio de crítica feminista sin clasificarse como tal en aquel momento; por lo anterior, considera a Rosario Castellanos como "la madre y la maestra del feminismo contemporáneo en nuestro país."39

Si bien Rosario Castellanos hace una propuesta de corte feminista en su tesis de maestría en 1950, no es sino hasta 1969 cuando se crea el Centro de Iniciativas para el Desarrollo Humano en América Latina (CIDHAL) a instancias de Betsie Hollands, Alaíde Foppa, Sylvia Marcos y Elena Urrutia. Una de las primeras actividades de este centro fue la publicación del Boletín

\footnotetext{
${ }^{37}$ Graciela Hierro, "Madres simbólicas del feminismo en México". p. 37.

${ }^{38}$ Loc. cit.

${ }^{39}$ Loc. cit.
} 
Documental Sobre las Mujeres y en 1976 comenzó a publicarse la revista Fem, "Primera revista feminista de América Latina" ${ }^{40}$ la cual tenía como objetivo principal difundir las investigaciones sobre mujeres.

Los primeros cursos sobre la mujer a nivel licenciatura fueron "ofrecidos a mediados de los años setenta en la Escuela Nacional de Antropología e Historia y en la Facultad de Ciencias

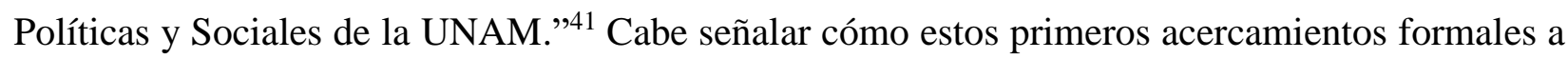
los estudios de la mujer se dan casi al mismo tiempo que el primer programa de licenciatura al respecto en los Estados Unidos.

Por otra parte, al encontrarnos en un mundo conectado por un sistema económico y político comunes, las tendencias culturales también se trasladan de un país a otro. No obstante, como México es un país tan diverso y grande, es difícil que las corrientes de pensamiento permeen en todo el territorio. En el artículo "Los programas y centros de estudios de la mujer y de género en México", escrito por Dora Cardaci, Mary Goldsmith y Lorenia Parada-Ampudia, se menciona la existencia de algunos grupos de trabajo en Estados como Oaxaca, pero la mayor parte de la investigación se concentra en los del centro del país.

Para los años 80, se amplía el trabajo sobre los estudios de la mujer y se crea el Programa de Integración de la Mujer al Desarrollo del Consejo Nacional de Población. Recordemos que, en la tabla 1, el objetivo marcado para esta etapa era hacer partícipe a la mujer en los avances del desarrollo, por lo que hay una congruencia entre los movimientos culturales; y también apoyo institucional en armonía con las políticas marcadas por los acuerdos internacionales.

Es cierto que la educación no es una prioridad del Gobierno en México y no lo ha sido nunca, por lo cual la mayor parte de los programas de género se vio forzada a buscar ingresos de

\footnotetext{
${ }^{40}$ Dora Cardaci et al., "Los Programas y centros de estudios de la mujer y de género en México", p. 247.

${ }^{41}$ Ibid., p. 249.
} 
manera independiente; no obstante, se fueron abriendo paso entre las dificultades y en 1983 se formó la Asociación Mexicana de Estudios de la Mujer, afiliada a la Asociación Latinoamericana y del Caribe de Estudios de la Mujer. En el mismo año, se abrió el Programa Interdisciplinario de Estudios de la Mujer en el Colegio de México; en 1984 el área de investigación Mujer, Identidad y Poder de la Universidad Autónoma Metropolitana, Unidad Xochimilco, y el Centro de Estudios de la Mujer, de la Facultad de Psicología de la UNAM. También comenzaron los estudios de este tipo en la Universidad Autónoma de Puebla y en el Colegio de Posgraduados en Ciencias Agrícolas; el Taller de la Mujer, que era un centro de atención a la comunidad en la Universidad Autónoma Metropolitana, Unidad Azcapotzalco, y en la Universidad Autónoma de Chiapas.

En el artículo anteriormente mencionado, "Los programas y centros de estudios de la mujer y género en México", se señala la creación de al menos quince de éstos, entre los que se encuentran aquellos que "rearticulan fragmentos de diferentes disciplinas para enfocarse en la problemática social específica." ${ }^{" 42}$ De los quince mencionados, varios desaparecen por falta de recursos. Entre ellos están el de Estudios de Género de la Universidad Autónoma de Juárez, el Programa Interdisciplinario de Investigación y Estudios de Género de la Universidad Iberoamericana del D.F., la Especialización en Género de la Maestría en Psicología de la Universidad de las Américas, el Taller de la Mujer de la UAM Azcapotzalco y el Centro de Estudios de la Mujer de la Facultad de Psicología de la UNAM.

Para el año 2000, existen cursos y diplomados sobre estudios de la mujer y género en las Universidades de Michoacán, Colima y en la UNAM; una Especialización en Género y Educación en la Universidad Pedagógica Nacional, y una Especialización en Estudios de Género en El Colegio de México; un Programa Integral de Especialización-Maestría en la UAM Xochimilco; dos áreas

${ }^{42}$ Ibid., p. 256. 
de concentración sobre la mujer en la Maestría en Estudios Rurales del Colegio de Posgraduados en Ciencias Agrícolas, y el Doctorado en Ciencias Sociales de la UAM Xochimilco.

Según Cardaci, Goldsmith y Parada-Ampudia, la investigación sobre programas de estudios de las mujeres y de género es un campo poco abordado por la academia y coincido con ellas, ya que en mi búsqueda bibliográfica me encontré con la falta de artículos específicos al respecto, no sólo acerca de la evolución de los programas de estudios en México, sino también por la ausencia de una cronología de estos en Estados Unidos e Inglaterra. Menciono estos dos países ya que son considerados pioneros de estas disciplinas, por lo que una rama de investigación podría ser la evolución de los programas de género y su relación con las políticas internacionales, lo cual permitiría una perspectiva de cómo la globalización se va conjuntando con la academia y la discusión de qué ocurre primero: el planteamiento de políticas o los cuestionamientos sociales al sistema.

A lo largo de estas primeras páginas, hemos visto cómo la perspectiva de género se hace presente en la cotidianidad, pero también se denota que todavía hay mucho trabajo por hacer, por lo que mi investigación se hace pertinente en estos tiempos de cambio e integración social. En cuanto a los Estudios de Género en el campo de la educación, en la introducción hice un recuento de las líneas de investigación que se siguen al respecto. Sí hay una inclusión de la perspectiva de género, pero aún se centra en cuestiones más sociológicas que pedagógicas.

Para integrar la perspectiva de género transversalmente en el currículo nacional, considero imperioso incluirla particularmente en cada uno de los programas para después trazar una ruta que lleve a la tan deseada transversalidad. Desde mi perspectiva, la inclusión de conceptos que deconstruyen paradigmas tan arraigados como con los que trabaja la perspectiva de género se debe hacer de forma paulatina y desde productos culturales, de tal modo que se normalicen los conceptos, al menos en el ámbito escolar. Pese a las complejidades que se pueden presentar en el 
proceso, debemos modernizar y actualizar los contenidos de nuestros programas, no sólo por mandato social internacional, sino por el bienestar de futuras generaciones. Si no comenzamos a deconstruir el habitus desde una perspectiva crítica, no lograremos incorporar la tolerancia y disminuir la discriminación en la sociedad mexicana.

Para concluir con los conceptos necesarios para plantear mi trabajo de investigación, es de suma importancia revisar las propuestas didácticas de Guadalupe Jover y Adain Chambers, quienes van a guiar mi trabajo. Chambers parte de la premisa de que la lectura "no tiene que ver sólo con pasar la vista sobre las palabras impresas, sino que es una acción dramática." ${ }^{\text {"3 }}$ Con esto deja claro que entiende el proceso lector como un conjunto complejo de actividades cognitivas que se engarzan y ayudan al lector a llegar a una comprensión cabal del texto. Para Chambers, la función de un profesor de literatura es "ayudar a que los niños participen en el drama de la lectura, ayudarlos a convertirse en dramaturgos (reescritores del texto), directores (intérpretes del texto), actores (representantes del texto), público (receptores activos y sensibles del texto), incluso críticos (comentadores, explicadores y estudiosos del texto)."44

Es evidente que Chambers entiende el proceso lector en su complejidad, lo desmenuza y elabora una propuesta que tiene como base la socialización del texto y, por medio del intercambio entre pares y con ayuda del maestro o facilitador, se llega a una comprensión más profunda del mismo. Retomo esta propuesta porque considero que utilizando este método a través de las preguntas correctas se puede evidenciar el currículum oculto y fomentar la reflexión en torno a este en los alumnos sin llegar a crear un ambiente hostil para nadie, especialmente en la época del \#miprimeracoso y \#Metoo. ${ }^{45}$

\footnotetext{
${ }^{43}$ Adain Chambers, Dime: los niños, la lectura y la conversación, p. 16.

${ }^{44}$ Ibid., p.36.

${ }^{45}$ Los hashtags \#MeToo y \#miprimeracoso dieron pie a un movimiento internacional que desató una gran cantidad de denuncias de acoso, que visibilizó la gravedad del problema de normalización de la violencia de género. En algunas
} 
Guadalupe Jover propone un acercamiento a la enseñanza de la literatura cuyo primer punto expresa que debemos entender la enseñanza de la literatura como "educación literaria", ya que la intención real es "el desarrollo de aquellos conocimientos, estrategias y actitudes necesarios para devenir en lector competente y autónomo de (buena) literatura a lo largo de toda la vida." ${ }^{46}$ Para Jover, al igual que para Chambers, la enseñanza de la literatura va más allá que el mero hecho de enseñar a los estudiantes a descifrar el código que se encuentra en las páginas; el objetivo es que se conviertan en verdaderos lectores: que logren disfrutar la lectura. Es decir, ambos autores pugnan por la recuperación de la característica lúdica de la literatura. Otro punto más formal que trata Jover es la falta de "una transformación de contenidos, metodología, criterios y procedimientos de evaluación” ${ }^{47}$ para lograr dar una verdadera educación literaria, con la que los alumnos lean obras de literatura completas y no solo fragmentos, es decir, que en verdad lean literatura compleja.

A partir de estas observaciones, Jover elabora la propuesta didáctica de las constelaciones, la cual brinda al docente la posibilidad de integrar una mayor cantidad de textos en su actividad ya que no contempla la organización historicista de la literatura y permite que los alumnos lean textos interesantes, cercanos a su realidad y no dar una lectura obligatoria. La propuesta parte de la presentación de varios textos unidos por un eje temático o temporal, a través de pequeños cortos o tráilers -haciendo referencia a los tráilers de las películas, cuya función es despertar la curiosidad del espectador-y permitir a los alumnos escoger sus lecturas para trabajarlas de forma grupal.

Una de las líneas de este trabajo es, justamente, el cuestionamiento al corpus de lecturas del Programa. Este es el punto en el que coincido con Jover, pues mi propuesta de ninguna manera se contrapone con el principio de enseñar literatura para su disfrute. Es más, desde mi entender

\footnotetext{
sociedades y grupos sociales se polarizaron las relaciones entre hombres y mujeres ya que los hombres sintieron que se encontraban en un ambiente de cacería de brujas.

${ }^{46}$ Guadalupe Jover, Constelaciones literarias. Sentirse raro. Miradas sobre la adolescencia, p. 10.

${ }^{47}$ Loc. cit.
} 
docente, el goce literario es indispensable para lograr una reflexión crítica profunda. Para lograr mi objetivo considero que la conjunción de las propuestas de Jover y Chambers me permitirá presentar un ejemplo de trabajo en clase útil para acercar a los alumnos al texto, fomentar sus capacidades lectoras y, a la vez, cuestionar el currículum patriarcal oculto. Para esto, será necesario trazar una línea histórica de la enseñanza de la literatura en México, lo cual da inicio al capítulo subsecuente. 


\section{Capítulo II. Análisis del programa de Literatura mexicana e iberoamericana}

\subsection{Análisis histórico de la materia de Literatura mexicana e iberoamericana}

La historia de la enseñanza de la literatura en la Escuela Nacional Preparatoria (ENP) se puede trazar a partir del 18 de octubre de 1574, año en que la Orden de Jesús abre las puertas del Colegio Máximo de San Pedro y San Pablo e inicia actividades en las que se conocían como facultades menores, donde se enseñaba gramática y humanidades. Los cursos de este nivel educativo tenían una duración de tres años y, como base, el aprendizaje del latín, que se complementaba con las clases de catecismo. Una vez concluidos "los estudios de gramática el escolar podía cursar las

humanidades: poesía y retórica." ${ }^{48}$ Decidí comenzar mi revisión histórica en este punto, ya que el nivel de los estudiantes que ingresaban al Colegio Máximo correspondía a lo que ahora consideraríamos secundaria y preparatoria. Los estudios inferiores tenían una duración aproximada de 5 años y los ciclos siguientes, que eran los estudios superiores, sumaban 9 años hasta el doctorado.

Otro elemento que me llevó a tomar este momento de la historia como punto de inicio fue la importancia de la literatura y la selección cuidadosa de los textos en el proyecto jesuita. Es cierto que no existe una materia dedicada a la literatura como tal -esto no ocurrirá sino hasta mediados del siglo XIX con la influencia del positivismo francés-; no obstante, el uso de textos literarios clásicos como base para la enseñanza de la lengua y "para [que los jóvenes puedan] estudiar en los humanistas clásicos los valores permanentes del hombre a través de ideas, sentimientos y actitudes; todos ellos son aspectos que superan las circunstancias de cualquier etapa histórica y que por esta

\footnotetext{
${ }^{48}$ Clementina Díaz de Ovando, El Colegio Máximo de San Pedro y San Pablo.
} 
razón merecían el reconocimiento de los grandes maestros universales." ${ }^{49}$ Vemos aquí que la literatura es un elemento fundamental en el modelo educativo jesuita.

La enseñanza jesuita tenía como base un documento llamado Ratio Atque Institutio Studiorum Societatis Iesu, que es lo más parecido a un plan de estudios actual. En el documento se marcan las directrices a seguir por todos los miembros de la comunidad educativa y, aun más importante, se describen los estudios, su duración y la metodología para su impartición. Se puede decir que, aunque los jesuitas no son los primeros en llevar a cabo el diseño de un documento guía para la impartición de la educación, sí son ellos quienes lo traen a México y sigue siendo parte de sus fundamentos, no solo de la ENP, sino de todos los niveles educativos del país.

De acuerdo con Clementina Díaz y de Ovando, el método educativo que seguían los jesuitas era el silogístico, que buscaba que los alumnos llegaran a sus propias conclusiones a través de la deducción: "Con el fin de estimular a los escolares, los jesuitas instituyeron actos literarios públicos y privados; oraciones y declamaciones recitadas en la cátedra; representaciones de comedias y coloquios latinos para fiestas y solemnidades." ${ }^{, 50}$ Veremos que para el modelo educativo de esta época, la literatura jugaba un rol importante, no sólo como el ejemplo de la máxima expresión de la lengua que requiere ser analizado en sus facetas gramaticales, sintácticas y retóricas, sino que además se rescata su carácter lúdico y se utiliza como herramienta de convivencia e interacción por los estudiantes. Por tanto, la literatura juega un papel relevante para la vida académica de la época; es parte de los elementos fundacionales del sistema educativo y, a más de 400 años de distancia, aún conservamos en nuestros atropellados y cuestionables programas actuales muchas de las propuestas jesuitas.

\footnotetext{
${ }^{49}$ Labrador Herraiz, "La Ratio Studiorum de 1599. Un sistema educativo singular".

${ }^{50}$ Clementina Díaz de Ovando, El Colegio Máximo de San Pedro y San Pablo.
} 
En 1767 los jesuitas fueron expulsados de México y en el siglo XIX Benito Juárez declara la separación Iglesia-Estado. En la Constitución de 1857, el Gobierno expropia los bienes de la Iglesia y, junto con los edificios, asume la responsabilidad de la educación y se comienza a formar un sistema de educación pública. Durante el Porfiriato, se nombra a Gabino Barreda como Secretario de Educación Pública y, con él, llegaron las teorías de Augusto Comte, en las que se privilegiaba a las ciencias exactas y el uso del método científico. Es justamente en este periodo en el que se consolidan los estudios de la ENP a cargo de la Universidad Nacional. En 1868 se funda la Escuela Preparatoria y hay un importante cambio en cómo era concebida la educación: los estudios se organizan a lo largo de 6 años. En este momento todavía no se hace la diferenciación precisa entre la secundaria y la preparatoria e incluso se puede observar una clara herencia de la organización jesuita en lo referente al nuevo modelo. El cambio más significativo es que, desde el principio del ciclo, los estudios se orientan a la especialización por campo y por carrera. El plan de estudios se organiza de forma enciclopédica, es decir, se ve una seriación o consecución lineal y se da prioridad a las materias científicas.

En estos primeros años de la Escuela Nacional Preparatoria hay cambios que van de la mano con los intereses económicos, políticos y culturales del país y, a la par, el plan de estudios se va modificando. El profesor Miguel Ángel Cevallos resume estos cambios de forma magistral en el documento que sustenta su propuesta de modificación al plan de estudios el cual se encuentra en los archivos históricos de la ENP y no tiene fecha; por su contenido y por la publicación de un plan de estudios modificado, creo que el documento se elabora en algún momento entre 1922 y 1923:

Desde la fundación de la Escuela N. Preparatoria en 1868 hasta el presente año, se han sucedido con intervalos variables catorce planes de estudios. El plan de mayor vigencia fue el de Gabino Barreda, 1869, duró veintisiete años consecutivos; el de menor vigencia fué (sic) el de Alfonso Caso, en 1929, apenas si alentó mes y medio, muriendo en la cuna por golpe traumático. El plan 
de 1896 duró cinco años, el de 1901, seis años y el de 1907, siete años. Los planes de 1914-16-1820-22, como se ve duraron dos años, precisamente dos años, con ritmo inexplicable. ${ }^{51}$

Siguiendo la línea marcada por este recuento, iniciaré con el plan de estudios de 1869, en el que las carreras que se imparten son para la formación de abogados, médicos, farmacéuticos, agricultores, veterinarios, ingenieros, arquitectos, ensayadores y beneficiadores de metales. En este programa, la materia de literatura general ocupa un lugar importante en la formación, ya que se incluye en todas las carreras. Los arquitectos, ensayadores y beneficiadores de metal toman literatura en el tercer año de secundaria y los demás en el quinto año de preparatoria.

En el Plan de 1896, no hay una clara separación por carreras y los cursos se dividen en ocho semestres; la materia de literatura general ${ }^{52}$ se imparte en el quinto y sexto semestres. En el plan de 1901 no se especifica si los estudios se reparten en semestres o años, aunque por la organización se puede inferir que es por semestres y en lugar de ocho son seis. En este plan, es la primera vez que se hace una diferenciación explícita en cuanto a la materia de literatura; en el quinto semestre se imparte la materia de Literatura general y en sexto semestre, Literatura española y patria.

Para 1907, la asignatura regresa al nombre de Literatura y se cursa en el primer y tercer semestres. La siguiente modificación es en $1914 ;^{53}$ este plan se divide en seis semestres: en el cuarto se estudia Literatura española, en el quinto Literatura mexicana y sudamericana, en el sexto, Literatura general. Esta es la primera vez que aparece el término Literatura mexicana en un plan de estudios. El siguiente documento es de 1918 y en él pareciera que sólo se estudian cinco

\footnotetext{
${ }^{51}$ Miguel Ángel Cevallos, Fundamentación del nuevo Plan de Estudios de la Escuela N. Preparatoria.

${ }^{52}$ Asumo que es literatura general, porque se le nombra así en uno de los planes de estudio y después sólo aparece con el nombre de Literatura hasta el plan de 1901, en el que ya recibe el nombre de Literatura española y patria.

${ }^{53}$ Es importante recordar que siendo México un país muy grande, el movimiento revolucionario avanzó de forma paulatina y no afectó de forma directa las actividades administrativas que se llevaban a cabo en la capital del país, por lo que aún en momentos de revuelta se desarrollaron proyectos en la Universidad.
} 
semestres; se propone la materia de Lectura y recitación en el tercer semestre y desaparece la materia de Literatura mexicana, para quedar sólo Literatura castellana en el quinto semestre.

En el plan de 1920, con José Vasconcelos como Rector de la Universidad Nacional y Ezequiel A. Chávez como director de la ENP, se replantea la educación y vemos una división de las materias por campo de conocimiento en donde la materia de Literatura general sólo se imparte a quienes van al campo de las ciencias sociales; aquellos que toman el área de lengua y letras llevan Lengua y literatura castellana. Este plan se modifica de inmediato y tenemos el plan de $1922,{ }^{54}$ que es el primero que aparece de forma desglosada en los archivos de la UNAM.

Este documento muestra que se hace una división por carrera y que los estudios tienen una duración de cinco años.

\begin{tabular}{|c|c|c|}
\hline Carrera & Literatura & $\begin{array}{l}\text { Año en que se } \\
\text { cursa }\end{array}$ \\
\hline \multirow{2}{*}{$\begin{array}{l}\text { Bachillerato en filosofía preparación para la } \\
\text { carrera de licenciado en derecho }\end{array}$} & Literatura castellana & $4^{\circ}$ año \\
\hline & Literatura general & $4^{\circ}$ año \\
\hline \multirow{2}{*}{$\begin{array}{l}\text { Bachillerato en filosofía preparación para la } \\
\text { carrera de licenciado en ciencias sociales }\end{array}$} & Literatura castellana & $4^{\circ}$ año \\
\hline & Literatura general & $4^{\circ}$ año \\
\hline $\begin{array}{l}\text { Bachillerato en filosofía preparación para la } \\
\text { carrera de médico cirujano }\end{array}$ & Literatura castellana & $4^{\circ}$ año \\
\hline $\begin{array}{l}\text { Bachillerato en ciencias preparación para la } \\
\text { carrera de ingeniero }\end{array}$ & Literatura castellana & $4^{\circ}$ año \\
\hline \multirow{2}{*}{$\begin{array}{l}\text { Bachillerato en ciencias y letras preparación } \\
\text { para arquitecto }\end{array}$} & Literatura castellana & $4^{\circ}$ año \\
\hline & Literatura general & $5^{\circ}$ año \\
\hline $\begin{array}{l}\text { Bachillerato en ciencias preparación para } \\
\text { cirujano dentista }\end{array}$ & Literatura castellana & $4^{\circ}$ año \\
\hline
\end{tabular}

${ }^{54}$ Universidad Nacional de México. Plan de estudios. 
Los planes para los que estudiarán química no incluyen ninguna materia de literatura.

Para 1930, ya con una universidad autónoma, se hace una nueva modificación en la que sólo quedan tres bachilleratos:

El de Letras clásicas y ciencias sociales, el de Ciencias biológicas y el de Ciencias físicomatemáticas. El primero se considera preparatorio para las carreras de Licenciado en Derecho y Licenciado en Economía; el segundo para la carrera de Médico Cirujano y el tercero para las carreras de Arquitecto, Ingeniero Civil, Ingeniero de Minas e Ingeniero Petrolero. Cualquiera de los bachilleratos será también preparatorio para optar grados en la Facultad de Filosofía y Letras. ${ }^{55}$

El Bachillerato en Letras y Ciencias Sociales tiene Literatura general como optativa en el tercer año; el Bachillerato en Ciencias Físico-Matemáticas tiene como materia obligatoria en el segundo año Literatura mexicana e Iberoamericana y como optativa Literatura general en el tercer año. Los ingenieros en sus distintas áreas, los químicos y los cirujanos dentistas no cursan ninguna materia de Literatura. ${ }^{56}$ Este documento se encuentra fechado el 11 de marzo de 1929 y está firmado por el rector Antonio Castro Leal.

En este último periodo, es de notar la ausencia de obligatoriedad de la materia en el área de Letras y Ciencias Sociales, en contraste con su presencia en el área de Ciencias Físico-Matemáticas. Aunque no hay ningún sustento teórico o pedagógico explícito para esta forma de organización, es posible suponer que, siguiendo las premisas de la educación jesuita, los interesados en el campo de letras y sociales cubrirían la parte de literatura dada su inclinación natural a la lectura. Por otra parte, se asigna la materia como obligatoria en el campo que pareciera estar más alejado de dicha actividad. No puedo, sin embargo, dejar de ver una contradicción en esta forma de organización del plan de estudios, ya que en los bachilleratos en Ingeniería y en Química y Salud, simplemente

\footnotetext{
${ }^{55}$ Universidad Nacional Autónoma de México, Plan de estudios 1930.

${ }^{56}$ Loc. cit.
} 
no se asigna ninguna materia de literatura, ni obligatoria, ni optativa. El hecho de que los físicomatemáticos son los únicos que tienen la oportunidad de cursar ambas materias es inusitado, sobre todo tomando en cuenta el ímpetu positivista que impulsaba a la educación, donde las ciencias exactas y el desarrollo tecnológico coronaban el espacio educativo, mientras que las disciplinas sociales y humanísticas se relegaban a éstas.

Hasta este momento de la historia de la materia de Literatura en la ENP, podemos ver que poco a poco se aparta del lugar central que ocupaba con los jesuitas, hasta desaparecer en los planes de bachillerato dedicados a las ciencias. Otro elemento que me interesa resaltar es la ausencia de menciones femeninas en todos los documentos revisados. Uno de los programas que duró dos años se elabora en conjunto, en un congreso de profesores de la ENP, y no se menciona la participación de ninguna mujer; para referirse al equipo de trabajo, se utiliza el sustantivo colectivo "Congreso de profesores" y no se detalla quiénes participaron en el proceso.

La realidad es que la documentación existente únicamente muestra firmas de hombres; por ejemplo, en el cierre del plan de estudios de 1926 aparecen las firmas de R. Sánchez, Francisco Monterde G.I y José D. Frías, y en los años anteriores tampoco encontré referencia a la participación de mujeres en la elaboración de los planes de estudio. En los archivos en los que hay datos sobre controles de asistencia y sobre nóminas pude notar que sí había profesoras impartiendo clase en la Escuela Nacional Preparatoria, sin embargo, hay poca claridad en cuanto a qué materias. Considero que este campo da pie a una investigación más profunda sobre la historia de las mujeres que han participado en los procesos educativos.

Los siguientes cambios significativos no se dan sino hasta 1948, después de la Segunda Guerra Mundial. En 1956, después de la formación de la ANUIIES, ${ }^{57}$ se lleva a cabo una revisión

\footnotetext{
${ }^{57}$ Asociación Nacional de Universidades e Instituciones de Educación Superior. La ANUIES es una organización no gubernamental conformada por 191 instituciones educativas tanto públicas como privadas. Se funda en 1950 y busca
} 
de los planes de estudio y se hace una nueva modificación; y en 1972 se comienza a utilizar el sistema de créditos que sigue vigente. En este lapso desaparecen los tres bachilleratos, dando paso a uno único que ofrece cuatro áreas de conocimiento en el último año y en el que se imparten las tres literaturas a lo largo de los estudios: Lengua y literatura española, Literatura mexicana e iberoamericana y Literatura universal. Lengua y literatura española se modifica poco y casi siempre es materia de $4^{\circ}$; las otras dos literaturas son las que cambian y hay un momento en el que ambas materias comparten espacio en el último grado o se separan y se queda una por ciclo. En los últimos años, se han hecho trabajos para modificar nuevamente los planes de estudio, cuyo último planteamiento data de 1993. En el 2016 se aprueba la actualización del plan de $4^{\text {o }}$ año de preparatoria y en abril de 2018 se autoriza el nuevo programa de Literatura Mexicana e Iberoamericana para $6^{\circ}$ grado.

En todos los textos revisados, las lecturas específicas del curso quedan siempre a criterio del docente y únicamente se hace una serie de recomendaciones de autores, libros de texto o, al final del programa, se propone una lista, esto es a partir de la modificación del $93 .{ }^{58}$ En el programa que se utilizó hasta mayo de 2018, en esta lista encontramos 79 autores entre mexicanos y latinoamericanos, así como 7 autoras, no todas mexicanas. Esta distribución será la constante en los libros de texto diseñados para la ENP. Pude constatar lo anterior a través de la revisión de algunos de los libros de texto propuestos en la bibliografía y, dado que estos libros están hechos a medida, sostienen la visión historicista de la literatura.

Uno de los textos que aparece en casi todas las unidades de este último programa es el de Literatura mexicana e hispanoamericana: manual para uso de los alumnos de la escuela

contribuir al fortalecimiento institucional a través de declaraciones, aportaciones y directrices. También trabajan de manera conjunta en la creación de programas nacionales de educación superior buscando el impulso a la docencia, la investigación y difusión de la cultura.

${ }^{58}$ Cfr. Apéndice 1. 
preparatoria, escrito por María Álvarez Edmee, cuya primera edición data de 1957 y la última de 2004. En un análisis de las lecturas y del acercamiento con el que se trabaja en este libro, encontré que en la edición de 1957 se integra a Sor Juana, quien será un caso excepcional, ya que aparece en el programa como autora consagrada, se le dedica espacio en una unidad y es la única autora que aparece en todos los libros de literatura mexicana. Las otras que aparecen en este material son la chilena Gabriela Mistral y la uruguaya Juana de Ibarborou. Para la siguiente edición, que se publica en 1993, se agrega un apartado al final del libro que se titula "Voces femeninas", en donde se incluye a las autoras ya mencionadas y a la argentina Alfonsina Storni; en cuanto a las letras mexicanas, se incorpora a María Enriqueta Camarillo y Margarita Michelena. En las ediciones posteriores, de 2002 y 2004, ya no hay cambios en el texto.

Otro libro que se repite en las recomendaciones del programa es Literatura mexicana $e$ hispanoamericana, de Josefina Choren Borbolla et al., del cual revisé las ediciones de 1985 y 2004. En la primera edición tenemos a la omnipresente Sor Juana y no es sino hasta la edición de 2004 cuando se integra a Rosario Castellanos y a Elena Poniatowska. En tres textos más los resultados son similares: el libro de Elsa María Cano Bonilla, Manual práctico de literatura mexicana, e igualmente encontramos a Sor Juana y a Nellie Campobello. María del Carmen Millán en su obra Literatura mexicana trabaja únicamente a Gabriela Mistral y a Sor Juana. Finalmente, el libro en el que encontré más mujeres fue el texto de Eva Lydia Oseguera, Historia de la literatura mexicana: S. XIX, en el que incluye a Isabel Prieto de Landázuri, a Laura Méndez de Cuenca y a la condesa Calderón de la Barca. En textos más modernos, que no forman parte de la bibliografía propuesta en el programa, sí hay más autoras, no obstante, siempre es una mínima cantidad en comparación con el número de autores. ${ }^{59}$

\footnotetext{
${ }^{59} \mathrm{Me}$ parece importante mencionar que muchos de los libros de texto son elaborados por mujeres y pese a ello se incluyen pocas autoras. Una explicación puede ser el apego a los programas y otra puede ser que simplemente no se
} 
El nuevo programa de Literatura, que se utilizará por primera vez en el periodo escolar que inicia en agosto de 2018, tiene una serie de cambios significativos en el enfoque, la organización de los contenidos y la aproximación a asuntos de género. Lo que considero más innovador es el alejamiento de la tradición historicista y la incorporación de ejes temáticos. Las unidades se organizan en torno a un tema específico relativo a la cultura, la sociedad o la humanidad en general, ya partir de este se proponen lecturas que llevan al alumno a reflexionar al respecto. Dentro de cada una de las unidades hay temas referentes a la parte formal de la literatura, como el tipo de narrador, la verosimilitud, características de algunos textos poéticos, etcétera y se espera que estos conocimientos se revisen enmarcados por la línea temática propuesta; se busca una enseñanza de la literatura contextualizada y no diseccionada.

Esta organización da al docente una mayor libertad en lo que a la selección de lecturas se refiere. Aunque existe una serie de propuestas, lo ideal siempre es escoger las lecturas según las necesidades de la población estudiantil. Otra de las ventajas que encuentro en este nuevo programa es que se puede recurrir a métodos didácticos más incluyentes, en los que el alumno deja de ser receptor y participa de forma más activa en el aprendizaje e incluso puede aportar a la selección de lecturas, propiciando así un mayor interés en el curso.

Lo anterior me parece relevante ya que, hasta este momento, en todos los textos revisados, el alumno es visto como un mero receptor de conocimiento y no como un ser independiente que debe ser considerado en su complejidad humana. Josep Ballester y Noelia Ibarra, en su artículo "La tentación diabólica de instruirse. Reflexiones a propósito de la educación lectora y literaria", nos recuerdan la importancia de considerar el contexto y los gustos de los lectores para fomentar la lectura sin hacer de ella una obligación, un sacrificio o un castigo. Este enfoque se aleja de las

nota la ausencia de escritoras. Es tan normal que no se les mencione o que no sean incluidas en el corpus que ya no se cuestiona su pertinencia. Aparentemente no hay una reflexión sobre este tema. 
costumbres educativas en las cuales la biblioteca era el lugar de castigo para los alumnos inquietos y más bien brinda la posibilidad de formar lectores que disfruten el acto. Además, considero valiosísimo el hecho de abrir espacios para respetar los derechos del lector y permitir una mayor libertad, con lo cual lograremos lectores independientes capaces de tomar decisiones sobre su propia experiencia lectora.

No obstante, a pesar de todas las bondades que encuentro en este nuevo programa, al revisar las lecturas y la organización descubrí con tristeza que, pese a que sí hay una mayor mención de mujeres a lo largo de las lecturas propuestas por unidad, se mantiene una evidente disparidad de género. En la primera unidad, que tiene como título "Literatura y experimentación”, se mencionan 45 textos, de los cuales tres son escritos por mujeres. La unidad 2 propone 17 textos y sólo uno es escrito por una mujer; la unidad 3 continúa con la misma línea: se proponen 38 lecturas y sólo hay una escritora; la unidad 4 no menciona a ninguna; la unidad 5 incluye 90 textos, de los cuales cinco son escritos por mujeres. Hasta aquí, la disparidad de género es abrumadora, sin embargo, la unidad 6 se titula "La expresión femenina" y, como es de esperarse, sólo aparecen textos escritos por mujeres y, a pesar de que se les dedica toda una unidad, sólo se mencionan 62 textos. Es decir, en una estadística se hace evidente la desproporción. 


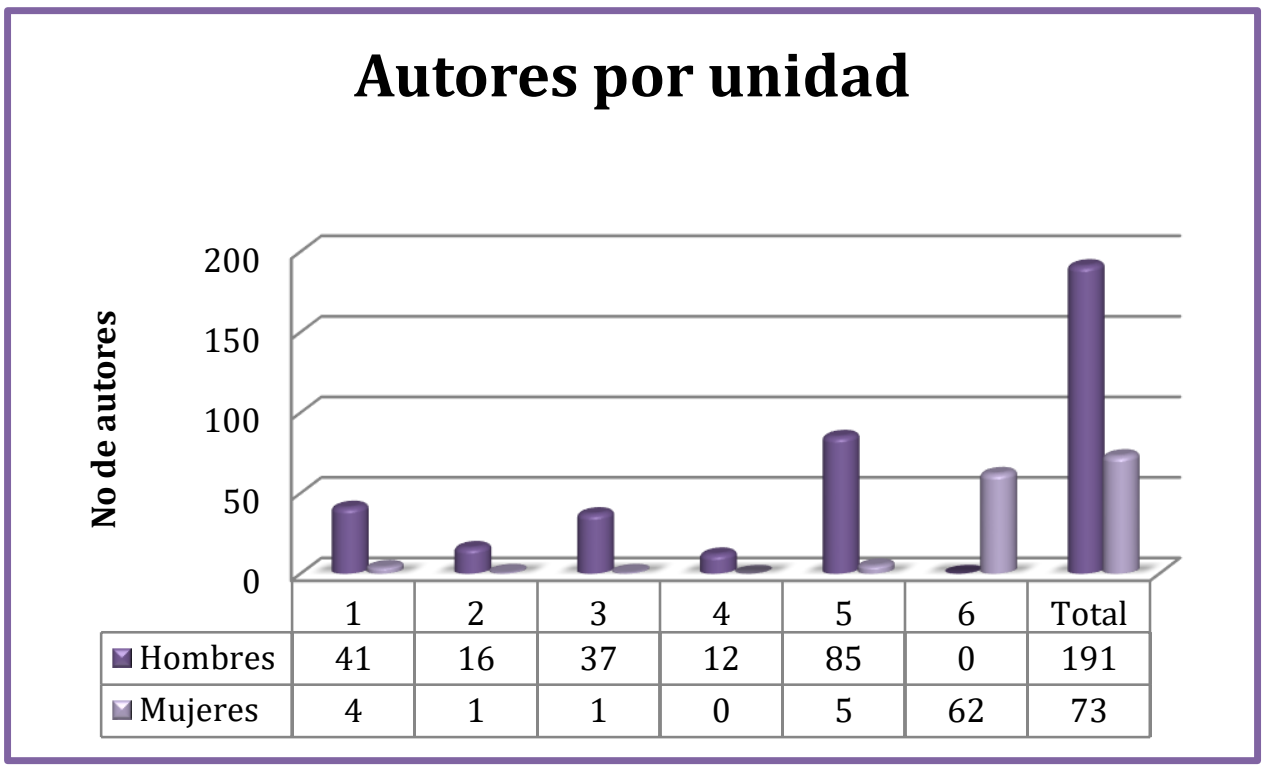

Con lo anterior, quiero demostrar que el hecho de dedicar una unidad completa a textos escritos por mujeres no hace que exista una distribución más equitativa, o más bien, no quiere decir que haya una verdadera representación del trabajo femenino. Para elaborar esta gráfica no eliminé a los autores que se repiten en algunas unidades, debido a que mi propuesta didáctica es congruente con este tipo de organización, es decir, hago una propuesta de acuerdo con cada unidad. A todo lo anterior cabe agregar que el número de autoras mexicanas en relación con las menciones a escritoras de otras latitudes sí es mayor.

Por último, diré que la deficiencia más grande que encuentro es justamente la división de la literatura escrita por hombres y escrita por mujeres. Esta división fomenta la ya muy criticada segregación de género que se utiliza en algunos transportes públicos y en otros espacios; además de que se basa nuevamente en el paradigma original, del que hablo en mi capítulo primero, de entender a la sociedad únicamente en el marco de un binomio y no verla como una amalgama de diversidades. Y aunado a la decisión de separar a las mujeres, los temas que enmarcan la unidad 6 fomentan los estereotipos de género. La unidad se titula "La expresión femenina”. El título en sí mismo ya es un elemento disruptivo porque lleva a la pregunta de si existe algún elemento que sea 
exclusivo de la literatura escrita por mujeres y si por ello se puede hablar de literatura masculina y literatura femenina y establecer una clasificación literaria a partir del género del autor.

Este no es un tema sencillo, ha sido debatido en varios foros, desde varias perspectivas e, incluso, en la misma corriente feminista encontramos posturas diversas. Dada la complejidad del asunto y que la discusión al respecto no aporta nada a mi investigación, sólo diré que comparto la posición de autoras como Hortensia Moreno, investigadora de la UNAM, quien dice que "afirmar la existencia de una forma de literatura femenina implica que existe alguna clase de esencia de la feminidad, que se expresa inevitablemente en la escritura de las mujeres. La afirmación de una literatura femenina significa entonces tomar posición a favor del pensamiento de la diferencia." ${ }^{60}$

La línea que guía este trabajo justo se aparta de la idea de la diferencia, de la separación y busca la inclusión, por lo que considero que el título de la unidad fomenta un estereotipo y no lo cuestiona, o como dice Sergio Sinay en su texto Las masculinidades tóxicas: "[hemos] caído en otro de los paradigmas trágicos de nuestra cultura: el dualismo, la necesidad de entender las cosas en términos de una contra la otra. Se pierde así la riqueza de la visión integradora, transformadora." ${ }^{61}$

Otra observación son los temas que se mencionan en la unidad 6, los cuales fomentan el estereotipo de género: “Amor, desamor y erotismo, cuerpo, maternidad, soledad, masculinidad, equidad, violencia de género, entre otros". Parte de la propuesta didáctica que presento es justamente cómo aproximarnos a todos estos temas desde una perspectiva que permita cuestionar si acaso no podemos hablar de desamor, de amor, de erotismo, del cuerpo, de paternidad y maternidad, de soledad, etcétera, en textos escritos por hombres y si no es posible encontrar

\footnotetext{
${ }^{60}$ Hortensia Moreno, "Literatura Femenina".

${ }^{61}$ Sergio Sinay, La masculinidad tóxica, p. 25.
} 
otredad, identidad nacional, naturaleza y espacio urbano, en textos escritos por mujeres. En resumen, la propuesta es cuestionar si no podemos acercarnos a los textos despojándonos de los prejuicios fundamentados en las jerarquías hombre/mujer. Finalmente, no puedo dejar de señalar que, a pesar de las observaciones que hago, el nuevo programa sí muestra un avance histórico en la inclusión de las mujeres; no obstante, carece de una perspectiva de género real y requerirá de modificaciones más profundas para alcanzar una propuesta más robusta y mejor informada en lo que a la inclusión de mujeres se refiere.

A lo largo de este segmento, hemos visto cómo los materiales reflejan la ausencia de autoras en los programas de estudios y también nos dan una clara idea de los procesos de integración de éstas en el campo literario; vimos que no hay mención de ellas sino hasta mediados de siglo XX y es hasta el programa aprobado en abril de 2018 cuando se incluyen de manera más evidente y formal. Considero que la inserción de las mujeres se dio de forma paulatina a principios del siglo XX como resultado de los espacios ganados durante el periodo de lucha inicial. Desde mi perspectiva, el programa de 2018 responde a políticas específicas de inclusión de género que, como mencioné, se han creado en organismos internacionales y han acelerado la inclusión femenina en varios campos; no obstante, las políticas no forzosamente tienen una injerencia rápida en los cambios más profundos, como serían los paradigmas culturales.

Para concluir este apartado, creo necesario agregar que soy consciente de que, si bien el integrar a mujeres en un programa de estudios y a una lista de autores no va a resolver los problemas sociales en México; ni tampoco, va a cambiar la mentalidad patriarcal por el sólo hecho de leer a mujeres, pero el no hacerlo, sí invisibiliza la mirada o las propuestas literarias que podrían identificarse con más de la mitad de la población ${ }^{62}$ y, como dice Guadalupe Jover: "Si los relatos

\footnotetext{
${ }^{62}$ Según el INEGI, hay 94.4 hombres por cada 100 mujeres.
} 
que leemos son determinantes en la construcción de nuestra identidad, no podemos prescindir de la mitad de la Humanidad: ni de la mitad que encarnan las mujeres, ni de la mitad que encarnan los pueblos no occidentales." ${ }^{63}$ En el artículo del cual tomé esta cita, Jover se refiere a la enseñanza de literatura universal y a la falta de inclusión femenina y de culturas no occidentales, pero dado que nosotros nos encontramos en un ambiente que adolece de los mismos males, su idea funciona muy bien para la propuesta de lecturas del programa de Literatura mexicana e iberoamericana.

${ }^{63}$ Guadalupe Jover, "Para que quepamos las mujeres habrá que cambiar los marcos”. 


\subsection{Análisis de los objetivos del programa de Literatura mexicana e iberoamericana}

Como dije anteriormente, para este análisis utilizaré la perspectiva de género y para elaborar las propuestas de lecturas recurriré a la transversalización que resulta ser una opción idónea, en combinación con la elaboración didáctica de Guadalupe Jover y Adain Chambers, por lo que se hace necesario ampliar este concepto ya que será la directriz de las propuestas. En el capítulo primero mencioné que la transversalidad es el punto de intersección entre varias áreas del conocimiento y es una magnífica herramienta para introducir nuevas formas de trabajo y valores en los alumnos, convirtiéndose en un reto para los docentes. En las siguientes líneas analizaré el texto de María Elena Camarena y María Luisa Saavedra en el que hacen una propuesta de integración de la perspectiva de género en los programas de estudio; considero que es el texto académico publicado en México que más se aproxima al planteamiento que hago en esta tesis. El fin de esta revisión es apreciar las diferencias y coincidencias entre ambas aproximaciones al tema y resaltar qué es lo que en verdad puedo aportar a este campo de la educación.

En el artículo "La perspectiva de género en los programas de estudio de las licenciaturas contables administrativas", María Elena Camarena Adame y María Luisa Saavedra García elaboran una propuesta para incluir la visión de género directamente en las materias que se imparten a los estudiantes de estas licenciaturas; es decir, crean materias que tratan específicamente los problemas que ellas encuentran en estas áreas. La principal diferencia que veo en relación con mi planteamiento es que su texto se enfoca en la integración de la perspectiva de género a nivel universitario y no en el bachillerato; por lo tanto, tiene un enfoque específico en materias dirigidas a replantear las políticas y en las aproximaciones que serán parte del perfil de egreso de los

profesionistas, lo que limita su alcance y se encuadra únicamente en esa carrera. Por el contrario, 
mi proyecto busca insertar la perspectiva de género en los salones de la ENP y llevar la reflexión sobre los entornos sociales y culturales a todos los ambientes en los que se busca trabajar con esta perspectiva.

Sin embargo, la aportación que Camarena y Saavedra hacen es muy valiosa: veremos que en el punto dos del artículo mencionan a Claudia Marinsalta, quien, en su artículo "Cuestionando las ausencias en el currículo" señala:

Se deben modificar profundamente los hábitos educativos con el fin de renovar el currículo mediante la transversalización de la categoría de género. Pues sostiene que el modelo de currículo actual está fundamentado en supuestos androcéntricos manifestado en los conceptos, metodologías y tácticas educativas, trayendo como consecuencia que las mujeres estén ausentes y silenciadas. Como solución, sugiere recuperar y revalorizar las contribuciones femeninas con el fin de eliminar los esquemas y formas de producción que la ideología dominante recrea a través de los tradicionales estereotipos sociales. ${ }^{64}$

Utilizan las conclusiones de esta autora para recalcar la incorporación de escritoras al programa, que es un primer paso para visualizarlas y revalorizarlas. En un segundo momento, incorporan la idea del "currículo oculto", elemento clave en el análisis literario y en la aplicación de la perspectiva de género. Para definirlo, utilizan las propuestas de Ivonne Velasco y Luz Maceira y conjuntando las perspectivas de ambas, llegan a una definición y mencionan la importancia de modificarlo:

Un medio para introducir el enfoque de género en las Instituciones de Educación Superior, dado que en toda institución educativa existe un "currículo oculto de género", es decir, una serie de valoraciones, códigos, normas, ideas, supuestos, mitos, discursos, conceptos, creencias, relaciones de poder, roles, recursos textuales y simbólicos generalizados y sexistas que se transmiten en la escuela y que refuerzan la discriminación femenina de manera poco visible. Por lo que

\footnotetext{
${ }^{64}$ Claudia Marinsalta, “Cuestionando las ausencias en el currículo universitario”, p. 15.
} 
propone la investigación, explicitación y transformación de los currículos ocultos de género como uno de los recursos fundamentales del proceso de incorporación de la perspectiva de género [...] dado que permite conocer los mecanismos de violencia y desigualdad y proponer acciones para cambiarlos. ${ }^{65}$

El énfasis en la importancia cultural del currículum oculto y su función como transmisor de patrones, se propone una aproximación a éste por medio de una visión crítica que genere conciencia y evidencie dichos patrones. La aportación más interesante de este texto es justamente esta reflexión, que retomaré para plantear algunos de los cuestionamientos en el tratamiento de los textos.

Hasta este momento, las fuentes revisadas me habían permitido constatar que la transversalización está aceptada globalmente y ha dado pie a cambios políticos, pero no se había trabajado de forma tan precisa en lo referente a un programa de estudios.

Camarena y Saavedra hablan de algunas de las dificultades para la implementación de la perspectiva de género, como la integración de los estereotipos de género en la dinámica escolar. Dado que la escuela está inmersa en una sociedad, es imposible aislarla de los estereotipos externos. ${ }^{66}$ La falta de trabajo colegiado, la escasa autonomía y la fuerte presión social de las escuelas impide la autocrítica y la reflexión: "El arraigo de los estereotipos de género, profundamente implantado en el currículum oculto de los docentes. La preponderancia del pensamiento hegemónico, de carácter androcéntrico, que de forma más o menos burda, preside y hegemoniza la vida de la universidad."; ${ }^{67}$ y también tenemos la prioridad dada a los contenidos

\footnotetext{
${ }^{65}$ María Elena Camarena Adame y María Luisa Saavedra García, "La perspectiva de género en los programas de estudio de las licenciaturas contables administrativas", p. 45.

${ }^{66}$ En Estocolmo, se han llevado a cabo experimentos para alejar a los estudiantes de los estereotipos en las aulas y no han sido del todo exitosos debido al contacto con los estereotipos en la cotidianidad. Cfr. Desaprender el género desde preescolar.

Camarena Adame y Saavedra García, op. cit., p. 55.
} 
explícitos, "contenidos que están impregnados (en su selección, en su estructura y en su misma epistemología) por elementos de carácter discriminatorio." ${ }^{\circ 8}$ Todas estas dificultades se encuentran en cualquier disciplina en la que se pretenda hacer un cambio, ya que, como bien lo mencionan las autoras, son aprendizajes milenarios que no se van a arrancar de tajo. Finalmente, el texto propone que para integrar la transversalización es necesario:

1) Revisar "a fondo, no sólo las competencias propias de la asignatura, sino el sesgo de género y la oportunidad de introducir ciertas perspectivas de género que tengan un significado consistente con la carrera a la que pertenece la asignatura."

2) "Crear materias específicas, temas y contenidos sobre los Estudios de Género"69

De estos dos planteamientos, el primero es el que utilizaré, debido a que es aplicable al programa ya existente. La segunda propuesta la considero poco viable, porque integrarla al programa de la Escuela Nacional Preparatoria implicaría una reestructuración completa del plan de estudios, lo cual sería deseable, pues ya es necesaria una revisión profunda. Sin embargo, la realidad es que un cambio de este tipo llevaría varios años de trabajo académico, ralentizado por muchas de las mismas razones por las que es difícil la inclusión de la perspectiva de género.

Es, pues, este texto una base interesante para mi trabajo de investigación, no obstante, es necesario hacer algunas precisiones. La perspectiva de género se debe integrar a los conocimientos escolares desde años previos; si en verdad se busca lograr una modificación del currículum oculto, es indispensable crear uno nuevo que se vaya insertando en las actividades cotidianas de los alumnos, en las relaciones con sus compañeros y en las expresiones del profesorado. No lograremos llegar a una verdadera inclusión de género si no comenzamos a trabajar antes y con esto me refiero a iniciar la labor desde niveles preescolares.

\footnotetext{
${ }^{68}$ Loc. cit.

${ }^{69}$ Ibid., p. 54.
} 
Coincido completamente con las autoras en que una forma de incursionar en los conocimientos académicos es a través del análisis del currículum oculto, pero como ellas bien lo mencionan, para lograr esto es necesario, no sólo preparar a los docentes, sino proponer formas de trabajo específicas. A partir de los conocimientos que he adquirido en el proceso de investigación para esta tesis, he llegado a la conclusión de que el paso que nos falta dar es llegar a las aulas, a la práctica docente. Hasta este momento, hemos avanzado en el camino para encontrar y sustentar de manera global las razones para integrar la perspectiva de género en la educación y se han trazado algunas directrices, pero requerimos de algo más tangible para los docentes. En un panorama idílico, en el que tenemos profesores y profesoras con los conocimientos fundamentales, con la disposición y el tiempo de llevar a cabo nuevas estrategias de aprendizaje y que tienen toda la intención de que sus alumnos construyan un pensamiento crítico, debemos lograr llevar todo hasta su salón de clases, a la práctica cotidiana de su materia, es decir, crear no sólo un programa bien revisado, sino construir una serie de herramientas didácticas que permitan al maestro trabajar con algo completamente nuevo en su entorno escolar.

Existe otro texto relacionado con mi preocupación, la tesis de licenciatura de Christian Esau Arzate Heredia, alumno de Pedagogía de la UNAM, quien en el 2012, presenta una investigación titulada Elementos teóricos y metodológicos para la incorporación de la perspectiva de género en el Currículum Universitario. En su texto hace una profunda revisión de propuestas teóricas y prácticas para incluir la perspectiva de género en el trabajo universitario, analiza, al igual que yo, los conceptos que son la columna vertebral de los Estudios de Género y que van a ser los puntos a partir de los cuales se plantea la reflexión de los contextos de los alumnos. Coincidimos en la importancia y la evidente necesidad de replantear las formas de trabajo en el ambiente escolar para incluir visiones diversas y la urgencia de comenzar por las aulas. Pero estamos en desacuerdo en algunos otros apartados: en principio, en el nivel educativo en el que se enfoca su trabajo. Yo 
insisto en comenzar en niveles escolares más básicos y no hasta la educación universitaria; otro punto en el que diferimos es que yo considero que es indispensable replantear el programa desde sus objetivos y reorganizar los contenidos; también, creo que es indispensable dotar al docente de una estrategia didáctica que le permita incorporar la perspectiva de género con la ilusa intención de subsanar la falta de capacitación sobre estos temas. A pesar de nuestras diferentes propuestas, en su tesis Arzate Heredia plantea dos elementos que me parece funcionan también para mi tesis. El primero es el proceso de intervención curricular que consta de cuatro pasos:

1. Diagnóstico de la institución educativa en términos de disposición y conocimiento en la materia de la intervención curricular.

2. Diseño de la o las modalidades de intervención curricular.

3. Implementación y seguimiento de los cambios curriculares.

4. Evaluación de la intervención curricular. ${ }^{70}$

Estos pasos constituyen el ideal de un proceso para la modificación de un programa escolar que, en muchas ocasiones, se ve interrumpido por los cambios políticos y sociales que influyen en la toma de decisiones sobre la educación.

El otro elemento que quiero retomar es la idea de curva de género, la cual se define como una serie de conocimientos básicos susceptibles de ampliarse poco a poco, conforme se avance en el tema. Esta propuesta tiene su origen en la curva de aprendizaje. El concepto proviene del campo de la producción de aviones y es una teoría que busca evaluar la efectividad del proceso repetitivo de ensamblado de aviones. Esta teoría nace en las ideas que introduce el economista estadounidense K.J Arrow en su texto "The economic consecuences or learning by doing". Con el tiempo, el concepto ha viajado a diferentes campos del conocimiento y en la educación se entiende que "la

\footnotetext{
${ }^{70}$ Christian Arzate, Elementos teóricos y metodológicos para la incorporación de la perspectiva de género en el Currículum Universitario, p. 74.
} 
trayectoria de la curva de aprendizaje describe el nivel de éxito obtenido durante una ventana de tiempo."71, es decir, la cantidad y efectividad de conocimientos adquiridos en un periodo de tiempo específico. Este concepto se ha complejizado en el campo de la educación e integra los periodos de olvido y la curva de atención de los estudiantes. Entonces, tenemos un proceso de aprendizaje óptimo que presenta un momento de olvido y para subsanar la pérdida se necesita revisar nuevamente los conocimientos para lograr una mejor retención y llegar a una mayor profundidad.

Al retomar este concepto, Arzate suscita la reflexión respecto a la necesidad de la repetición de los conceptos y de la importancia de incluir este tipo de temas de manera repetitiva en los programas de estudio; por lo tanto, el término que utiliza el autor de la tesis me parece más que pertinente para describir la forma en que se deberían insertar los temas de género. Cabe resaltar que entiendo esta integración en el marco de la transversalidad y nunca como materias aisladas o específicas para el trabajo de la perspectiva de género. Los dos textos anteriores forman parte del reducido panorama académico de México en el que se enmarca mi propuesta de integrar la perspectiva de género en el programa de la ENP y el uso de dos estrategias didácticas para la aplicación de la transversalidad en la materia de Literatura mexicana e iberoamericana.

En las primeras líneas de esta tesis mencioné que la combinación de la propuesta de socialización de Adain Chambers y el trabajo de los textos en constelaciones literarias como lo plantea Guadalupe Jover son las herramientas que permitirán incluir la perspectiva de género en el trabajo docente. La aplicación de éstas busca llevar a los estudiantes a una reflexión contextualizada sobre los temas de género y, a la vez, coadyuvará a formar lectores más autónomos y competentes respetando su individualidad y derecho a decidir, en congruencia con el nuevo enfoque del programa 2018.

\footnotetext{
${ }^{71}$ María Teresa Tortosa et al., XIII Jornades de XarXes D’ Investigació en docència universitària, p. 2418.
} 
Adain Chambers desarrolla su propuesta con base en observaciones prácticas y entrevistas a alumnos. El inicio de la estrategia parte de la intención humana de participar a los demás las experiencias; en este caso, veremos que se comparte la experiencia lectora. Pese a que la lectura es considerada como un acto individual en el cual se crea una relación íntima con el texto, Chambers nos enfrenta a una realidad que, como profesores de literatura, muchas veces omitimos o decidimos ignorar. Un lector experimentado es el que más va a disfrutar la lectura en soledad, pero eso no es impedimento para que comparta su experiencia, comente sus puntos de vista y observaciones en una reunión con otros lectores. Si para un ávido lector la conversación sobre sus textos es importante, lo es aun más para aquellos que van integrándose al mundo del goce de la lectura.

$\mathrm{Al}$ inicio de la experiencia lectora, compartir es un elemento fundamental para lograr un mejor proceso de comprensión del texto y Chambers aprovecha este proceso para utilizarlo de forma consciente en el aula. El autor describe tres momentos en los que el acto de compartir es el centro de la actividad: el primero es "compartir el entusiasmo" en una conversación común sobre algún texto. En un principio se comentan los detalles que generaron placer y aquellos que no; recordemos que es un ambiente lejano a la academia en donde no se esperan comentarios eruditos, sino más bien una reacción natural que describa cuál fue la relación personal que el lector entabló con el texto, es decir, se hace énfasis en el gusto del lector. Es muy importante que, como docentes de literatura, nos liberemos de los prejuicios de alta y baja literatura, de sentirnos con el poder de emitir juicios de valor respecto a la selección de textos de nuestros alumnos y, sobre todo, es primordial respetar sus gustos y no emitir una acotación acerca de estos con la intención de no cohibir sus experiencias y demostrar que no importa el resultado: la experiencia es individual y valiosa. Por lo tanto, una de las primeras habilidades que requiere el docente para aplicar este tipo de trabajo colaborativo es la prudencia y el respeto a las invaluables opiniones de sus alumnos. 
El segundo momento que describe Chambers es cuando se comparten los desconciertos o las dificultades encontradas en el texto, ya que van a variar dependiendo del lector y su contexto; es así cómo lo que para unos fue muy disfrutable, otros lo sintieron como un elemento disruptivo, ya sea que se hable de un personaje, alguna situación, el estilo de la narrativa, etc. Nuevamente, en este punto es muy importante que el facilitador promueva el respeto a las opiniones entre alumnos y que no permita burlas o comentarios como "ay, cómo no te va a gustar, es que no le entendiste", "seguro no leíste bien", "cuando aprendas a leer te va a gustar" ... Ante todo, las opiniones de los alumnos provienen de la conexión entre el texto y su entorno, por lo que una crítica a su opinión es una crítica directa a su realidad.

El último momento que Chambers describe es en el que se socializan las conexiones. Durante la conversación se habla sobre el texto en relación con el mundo, con otros textos y con otras experiencias; es el punto en el que se establecen nexos y comparaciones que van a enriquecer la lectura, la experiencia y al lector. Es justo aquí en donde se comienzan a crear las constelaciones, ya que a partir de estas conexiones se pueden unir nuevos textos a la discusión y engarzarse a la cadena que va a llevar a los alumnos a la reflexión y a conocer nuevos textos.

El medio para lograr todo lo anterior es la conversación. Chambers especifica que su propuesta está basada en "el modo conversacional básico, extendiendo el número de participantes de uno a uno, niño y adulto, a un adulto (facilitador) y comunidad de lectores cuyo mutuo interés está concentrado en un texto compartido. ${ }^{, 72}$ Es decir, centrar la atención de todos los participantes en un mismo tema permitirá una conversación enriquecedora que guiará a los alumnos a una mejor comprensión del texto. Si bien es cierto que encontrar textos que gusten a todos los miembros de

\footnotetext{
${ }^{72}$ Chambers, op. cit., p.24.
} 
un grupo es una labor difícil, Guadalupe Jover nos da varias opciones para resolver este asunto y llevar la actividad a buen fin.

Antes de elegir los textos, es necesario analizar la propuesta de Chambers quien nos pone en contexto explicando a detalle los modos de habla en los que incurrimos y cómo cada uno forma parte del proceso de conversación. El primero es "hablar para sí mismo"; al verbalizar algo pareciera hacerse más claro y Chambers reconoce esta actividad como parte del proceso de pensamiento que se refleja en comentarios como "sólo estoy pensando en voz alta” y “¿cómo suena esto?" Así como hablar para nosotros mismos ayuda a organizar las ideas, hablar con otros permite aclarar los pensamientos y comunicarlos. Esto nos lleva a establecer un intercambio en el que el proceso parte de información ya conocida y pensada individualmente, a información nueva, producto de la retroalimentación y del replanteamiento de los datos originales con base en lo nuevo que provea el interlocutor. Aquí es donde entran en juego los siguientes modos de habla mencionados por Chambers: "Hablar de lo nuevo" y "hablar juntos". En resumen, Chambers plantea un panorama muy específico de los procesos de socialización de un texto en la escuela. Yo propongo retomar estos procesos integrando una serie de preguntas elaboradas por el facilitador, que ayuden a la reflexión sobre temas de género.

En conjunto con la propuesta de Chambers, sugiero el uso de la metodología de Guadalupe Jover para la selección de textos y su uso en clase. La propuesta de Jover comparte con Chambers el origen: ambas surgen de las experiencias. Específicamente, Jover señala la necesidad de trabajar en conjunto para llegar a un modelo de lo "que podría ser un sustrato teórico común". ${ }^{73}$ Es muy probable que este punto cuestione por qué decidí utilizar una propuesta española en México; la realidad es que las preocupaciones de Jover son muy afines a las del programa que estoy trabajando

\footnotetext{
${ }^{73}$ Jover, "Para que quepamos las mujeres habrá que cambiar los marcos”, p. 9.
} 
en este texto y tienen objetivos son muy similares. Recordemos que Jover es una referencia de la bibliografía del programa.

Como describiré más adelante, algunos de los objetivos del programa hacen referencia a la necesidad de crear identidad nacional. En palabras de la autora, lo que se requiere es la construcción de imaginarios colectivos. La realidad es que nuestros alumnos ya tienen o cuentan con un bagaje colectivo definido desde su nacimiento; no obstante, a través de la escuela se refuerzan muchas de estas creencias, por lo que es importante seleccionar las lecturas en función de tales imágenes ya existentes en los alumnos y, al mismo tiempo, buscar que sean atractivas y que se encuentren dentro de su horizonte de expectativas para cumplir con los siguientes objetivos que dan a la escuela la "triple misión de enseñar a leer, consolidar hábitos lectores y compartir el imaginario colectivo".74

Si bien dichos objetivos parecieran ser muy ambiciosos, Jover plantea este modelo tomando en cuenta todas estas necesidades y haciendo algunas precisiones: la primera es que ciertamente la escuela debe tener presencia en el proceso de formación de lectores, pero debe ser de forma “consensuada, y planificada. [Se debe] hacer compatible la necesidad de transmitir y compartir un valiosísimo -y trasnacional- legado literario con una cierta flexibilidad que permita escoger los itinerarios y la mediación más adecuados a cada contexto escolar, a cada grupo de lectores."75 En esta cita, es posible notar la importancia de romper con hábitos de trabajo enciclopedistas y abrir la mente a recibir nuevas propuestas de lectura. Asimismo, la palabra flexibilidad es la clave para conseguir éxito con este modelo y, sobre todo, en el aula durante el trabajo con los alumnos.

Jover habla de puntos específicos que son necesarios. El primero es la necesidad de sacar la lectura de la escuela y llevarla a otros entornos, a "entornos sociales", para que así los alumnos desmitifiquen el acto lector y lo conviertan en una actividad lúdica. Otro elemento es el

\footnotetext{
${ }^{74}$ Ibid., p. 10.

${ }^{75}$ Ibid., p. 11
} 
cuestionamiento al corpus de lectura. Hay que preguntarnos: ¿qué están leyendo los alumnos? ¿por qué están leyendo eso?, ¿qué razones son las que nos llevan a seguir leyendo lo mismo desde hace décadas, si ya sabemos que no a todos les funciona? Su último punto es "aprender, de una vez por todas, a enseñar a leer (también literatura)". ${ }^{76}$ En este caso, se dirige al docente y explica la necesidad de realizar trabajo colegiado para que, de manera vertical, se puedan incluir textos de todas las materias en la enseñanza de la lectura.

Este último punto me parece fundamental para los objetivos de este trabajo, ya que, como lo he venido mencionando, para lograr una verdadera inclusión se requiere la transversalización. Jover dice que es necesaria para ampliar los horizontes de los alumnos; según yo, es indispensable para mostrar todos los puntos en los que la perspectiva de género cruza con otras materias a diferentes niveles. Es decir, la transversalización va más allá de ser un mero concepto de los estudios de género; se ha convertido en una necesidad para mejorar la didáctica y el aprendizaje de los alumnos. Para lograr lo anterior, habría que conseguir que la academia -entendida como el grupo de docentes- trabaje de forma colegiada.

Otra de las barreras que Jover critica es esta idea de canon de alta literatura y propone la necesidad de crear un canon más inclusivo, en el que no únicamente se lea literatura clásica, sino que exista literatura juvenil actual. Jover menciona en este caso un canon cosmopolita y, aunque no especifica con cuánta apertura, yo creo que debemos pensar en una visión más ambiciosa, por ejemplo, incluir textos de autores extranjeros que hablen de México o que hayan escrito en el país y no sólo que hayan nacido en él. Estoy consciente de que esta propuesta podría llevar al debate sobre si leer traducciones es buena idea o no, sin embargo, considero que sería importante incluir la mirada del otro para contrastar percepciones.

${ }^{76}$ Ibid., p. 11. 
Más allá de todo esto, Jover establece de manera muy precisa el modo en el que se debe construir una constelación literaria. Dice que se parte de una línea temática -así como está organizado nuestro nuevo programa-, un periodo histórico o algún otro elemento que tengan los textos en común y que permitan establecer una relación clara entre ellos. Esto es muy importante, pese a que la misma autora menciona que las constelaciones pueden resultar "caprichosas", es indispensable que el eje rector sea muy claro y preciso. También cabe aclarar que la autora utiliza el término "texto" desde su acepción más amplia y usa cualquier medio que presente una narrativa para incluirlo en las constelaciones.

Los pasos a seguir son: “Diseñar los itinerarios desde el emplazamiento de sus lectores”, "Conformar contextos de lectura", "Abordar la lectura en contrapunto". ${ }^{77}$ Nuevamente señala la importancia de incluir al alumno y su contexto en la selección. El segundo punto es pensar en que los textos deben estar graduados, es decir, van del más sencillo al más complicado, de forma que el alumno vaya incrementando su habilidad como lector. El último punto es relacionar obras literarias y no literarias para hacer más variado el trabajo y ampliar las posibilidades para los lectores.

En un primer acercamiento se puede pensar que este tipo de trabajo es en verdad muy complejo y quizá inalcanzable debido a los diferentes elementos que intervienen. Jover, muy consciente de esta preocupación, explica cómo todo se encuentra organizado de forma que se puedan conciliar las distintas paradojas que surgen en el salón de clases: comienza por la complejidad de enseñar literatura - ella lo llama intervención- en libertad. Dice que se debe ofrecer la oportunidad de leer por el mero gusto. La segunda contradicción que resuelve es que, por medio de este modelo, se pueden empatar las lecturas comunes - las lecturas que se hacen en conjunto- y

\footnotetext{
${ }^{77}$ Ibid.
} 
las lecturas personales; de la mano con este punto, viene la sincronización del imaginario colectivo -como mecanismo de cohesión de la sociedad- y la heterogeneidad y diversidad de cada uno de los espacios educativos. Este último punto me parece muy importante, especialmente en un país como México, en el que la situación geográfica y sociocultural es tan variada que hace prácticamente imposible establecer un solo contexto, sino que se requiere flexibilidad para abarcar todos los marcos en los que se puede encontrar la educación literaria.

Si se toman en cuenta todos los puntos anteriores, podemos llegar a la conclusión de que la integración de estas premisas lleva a establecer una relación más cercana entre los alumnos y los textos; permitirá ampliar las posibilidades de reflexión, y, sobre todo, abrir los panoramas para hacer que los alumnos se comprometan con la actividad lectora. Esto obliga a que el docente elimine prejuicios: así como para utilizar la propuesta de Chambers es necesario evitar los juicios de valor, con Jover es indispensable, nuevamente, deshacerse de los conceptos de alta y baja literatura, o que sólo los libros son literatura, ya que la intención es promover la lectura y que poco a poco los alumnos creen su propio criterio a través de la experiencia. Una vez elegidos los textos, se incentiva la lectura por medio de la curiosidad, despertar el interés de los alumnos en los diferentes materiales utilizando pequeños cortos o resúmenes para que ellos escojan el que más les atrae y lo lean. De esta manera se evita la obligatoriedad y se promueve el gusto por la lectura. La propuesta de Jover se centra en el lector y deja de lado al facilitador y con ello se cuestiona uno de los principales paradigmas de la educación tradicional.

Vemos que las dos propuestas comparten objetivos y, sobre todo, presentan un reto para los docentes, ya que se cortan de tajo hábitos y prácticas ancestrales tales como la educación centrada en el docente, la selección historiográfica de textos y la obligatoriedad de la lectura, además de la apreciación de la literatura como actividad de élite. Por lo tanto, considero que ambos planteamientos permiten la creación de secuencias didácticas funcionales y viables, no sólo para el 
aprendizaje literario, sino para la reflexión sobre temas específicos. Veremos que la transformación del programa nos da la posibilidad de utilizar estas técnicas gracias a su nueva organización y enfoque, los cuales revisaremos de forma más puntual en el siguiente capítulo a la luz de las premisas de Jover y Chambers, así como bajo la lupa de los Estudios de Género. 


\subsection{Análisis de los objetivos específicos y particulares del programa}

Como vimos a lo largo de la revisión histórica con que se abre este capítulo, la enseñanza de la literatura ha estado presente desde los inicios de la educación media superior en México y durante mucho tiempo se mantuvo una misma visión que pareciera haberse congelado en el tiempo. No obstante, el último programa de estudios muestra avances importantes en la perspectiva educativa y deja algunos cabos sueltos en lo relacionado a la perspectiva de género.

En su presentación, está como primer punto el propósito general:

La asignatura de literatura mexicana e iberoamericana tiene como propósito general que el alumno profundice en la competencia literaria, la cual se entiende como la capacidad de comprensión y producción de textos literarios, lo que permitirá al alumno desarrollar su sensibilidad estética mediante la lectura, la interpretación de obras literaria de autores mexicanos e iberoamericanos, así como ser consciente de las problemáticas sociales; todo lo anterior con el fin de fortalecer, integrar y aplicar los conocimientos, valores y actitudes de las distintas disciplinas humanísticas que reúne el Plan de Estudios del bachillerato de la UNAM. ${ }^{78}$

En esta primera parte encuentro una contradicción entre el propósito general y la metodología planteada. La formulación de Guadalupe Jover tiene como uno de sus ejes la promoción del disfrute, ya que es a partir de una actitud emocional favorable como lograremos que los alumnos se identifiquen con el texto y lleven a cabo un mejor proceso cognitivo: "El no valorar [los] componentes afectivo[s] del aprendizaje puede llevar incluso a efectos cognoscitivos contrarios a los deseados, por una relación de interferencia entre el dominio cognoscitivo y el afectivo." ${ }^{79}$ Considero que debería integrarse en el objetivo general el interés por fomentar la

\footnotetext{
${ }^{78}$ Universidad Nacional Autonoma de México, Programa Literatura mexicana e iberoamericana, p. 72.

${ }^{79}$ Marta Sanjuan Álvarez, "Leer para sentir. La dimensión emocional de la educación literaria”, p. 167.
} 
capacidad de disfrute de los alumnos, ya que de lo contrario sólo nos centramos en las capacidades prácticas que muchas veces son insuficientes para lograr formar lectores competentes y autónomos.

Entendamos el ser lector competente como lo plantea Víctor Moreno en su texto Preferiría no leer. Valores desagradables de la lectura. A lo largo del trabajo, el autor hace énfasis en la importancia de formar lectores que en verdad disfruten la lectura, ya que, si sólo son capaces de leer en función de objetivos prácticos y evaluables, como los planteados en la prueba PISA, la realidad es que no van a leer nada fuera del sistema educativo, no dedicarán tiempo libre a la lectura. Es decir, todo aquello que incluimos en los programas sobre reflexión de experiencias de otros y propias quedará en mero trabajo de aula y no se convertirá en una actividad que fructifique en la formación personal y que logré el objetivo señalado en el siguiente párrafo: “Al finalizar el curso, y con ello el bachillerato, el estudiante será un lector autónomo y con un amplio panorama de la literatura mundial, lo que contribuirá a su formación humanística y al desarrollo de una postura crítica, comprometida ante las situaciones planteadas en los textos leídos." ${ }^{80}$

También es necesario replantear el texto, ya que después de mencionar que el alumno conocerá la literatura universal, menciona: "No está de más añadir que abordar la literatura mexicana e iberoamericana es importante, dado que ningún panorama de la literatura universal estaría completo sin sus aportaciones y visión del mundo. Por otra parte, leer textos en lengua materna propicia tanto la reflexión de su uso como de sus posibilidades estéticas.”81 En estas líneas, se percibe una fuerte tendencia hacia el eurocentrismo, ya que en lugar de poner la literatura mexicana e iberoamericana-elementos centrales de este programa- como primordiales, las plantea como un elemento que se agrega al aprendizaje básico, que es la literatura universal ${ }^{82}$ y aparte es

\footnotetext{
${ }^{80}$ Universidad Nacional Autonoma de México, Programa de Literatura mexicana e iberoamericana, p. 2.

${ }^{81}$ Ibid., p. 3.

${ }^{82}$ Es importante cuestionar el concepto de literatura universal, ya que por lo general sólo se habla de literatura occidental y son muy escasos los textos de otras latitudes como la literatura oriental e incluso la literatura de países
} 
"importante" leer la literatura nacional. Finalmente, cuando menciona lo esencial de leer textos en lengua materna, no se considera a los estudiantes de bachillerato incorporados a la UNAM que siguen este mismo programa y que pudieran tener como lengua materna alguna lengua originaria. Recordemos que el nacimiento de los Estudios de Género estuvo rodeado de otros movimientos que cuestionan la hegemonía, por lo tanto, es necesario hacer notar estos factores cuando se lee con perspectiva de género.

Otro de los aspectos a tratar es la producción de textos. Se espera que, con base en la lectura, el alumno sea capaz de elaborar textos de diferentes géneros, en especial me referiré al párrafo en el que se habla de la elaboración de textos argumentativos:

En la escritura, el grado de complejidad aumenta sustancialmente en sexto año, pues el alumno trabajará el texto argumentativo: para ello partirá de la identificación de la estructura, del reconocimiento de argumentos y finalizará con la producción de ensayos literarios y académicos que incluyan tanto una argumentación fundamentada, surgida a partir del proceso de investigación, como un aparato crítico estructurados correctamente. ${ }^{83}$

Esta parte del programa es muy ambiciosa, especialmente porque no hay un diseño de contenidos orientado a la escritura. De manera general, nuestro sistema educativo no se estructura en función de la escritura, sino que se basa en la evaluación de aprendizajes adquiridos. Un sistema educativo fundamentado en la producción de textos es el anglosajón, utilizado en el Reino Unido y varios de los países que formaron parte de éste, incluyendo los Estados Unidos. Este tipo de sistema evalúa a los estudiantes a partir de la elaboración de textos desde los primeros años de educación formal,

como Noruega, Finlandia, Islandia o Australia. Propondría una revisión de programa de Literatura universal y casi puedo asegurar que el canon corresponde a países que en su momento fueron colonialistas y que se habla muy poco de países colonizados. Por ello, considero que la frase en la que se refiere a la integración de la literatura mexicana e iberoamericana al canon de literatura universal lleva algo de currículum oculto en el que se parte del centro hacia la periferia considerando como centro los países europeos.

${ }^{83}$ Ibid., p. 4. 
es decir, desde la primaria comienzan a entregar "papers" y, además, se comienza a explicar gradualmente la necesidad de escribir un párrafo con fundamentación y organización desde que comienzan su vida escolar. Por el contrario, el sistema educativo mexicano no toma este elemento como preponderante en la formación de sus alumnos, por lo que la idea de que para el sexto año de preparatoria los alumnos sean capaces de elaborar ensayos literarios y científicos, teniendo como base únicamente el ejemplo de las lecturas, me parece muy aventurado y poco realista.

Ya en el objetivo general, sí se menciona la parte de goce del lector: "La asignatura de Literatura mexicana e iberoamericana tiene como objetivo general que el alumno lea, comprenda e interprete obras representativas latinoamericanas, a partir del análisis y la producción de textos que contribuyan al fortalecimiento de su identidad, a su formación humanística, al pensamiento crítico y al goce estético." ${ }^{84}$ Dicha mención se encuentra como punto final del objetivo, cuando según Jover y Moreno debería ser el elemento principal. Para lograr el punto de "fortalecer su identidad" se requiere replantear la organización de los objetivos desde el general que pone en primer lugar el aprendizaje de la literatura universal -siempre cuestionando el concepto de "universal", que nunca incluye países asiáticos o africanos-y, como elemento extra, la lectura de literatura nacional y latinoamericana, siendo este elemento de aparente segregación.

A partir de este párrafo, veremos que el problema base que dio origen a esta tesis -la falta de mujeres en el corpus de escritores y que, recalcaré, no es un asunto que se limita a la literatura mexicana, sino que lo podemos ver en el programa de Literatura Universal e incluso en El canon Occidental de Harold Bloom, quien menciona a dos o tres mujeres en su texto- es más representativo de lo que parece a simple vista. Analizaré los objetivos de cada una de las unidades del programa, tomando en cuenta la falta de mujeres en cada unidad, y anexaré a los objetivos las

\footnotetext{
${ }^{84}$ Ibid., p. 3.
} 
ideas que yo considero son parte del currículum oculto. La inclusión será en color azul para facilitar la lectura.

Creo necesario en este punto recordar que mi propuesta no es sólo incluir mujeres, sino ver cómo trabajar textos tanto de hombres como de mujeres con perspectiva de género; no obstante, para este momento en que elaboro un análisis específico de la redacción del programa, el objetivo es evidenciar las ideas que pueden leerse entre líneas en la ausencia de autoras. De este modo, desglosaré en los siguientes párrafos el contenido por unidad, con la visión de los autores mencionados previamente y mi propio comentario sobre los temas.

La Unidad 1 tiene como título "Literatura y experimentación" y las mujeres que se mencionan en la parte de contenidos procedimentales son tres: Dina Grijalva, Elena Garro y Luisa Josefina Hernández. La primera se encuentra en el punto 1.8 "Selección y lectura de textos narrativos de diferentes épocas relacionados con las innovaciones de la narrativa (juegos temporales y espaciales, tipo y punto de vista del narrador, monólogo interior)"; las otras dos autoras aparecen en el punto 1.9 "Selección y lectura de textos dramáticos de diferentes épocas relacionadas con las innovaciones del teatro experimental". Como sólo se mencionan tres autoras en estos puntos, el mensaje a entender es que no hay ninguna escritora que pueda ser representativa o de interés para los otros apartados, por lo tanto, no hay textos escritos por mujeres que sean valiosos para el análisis de estos elementos.

Así, los objetivos específicos plantean que:

El alumno:

- Reflexionará sobre las innovaciones de forma y fondo en los textos literarios escritos en su mayoría por hombres a través de la lectura de obras representativas, para ubicar la literatura como quehacer humano en el que hay poca participación de las mujeres en constante transformación.

- Comprenderá las transformaciones artísticas y sociales de un mundo planteado desde la 
perspectiva de los hombres, su relación con sentimientos de angustia, de vacío o de ironía, así como la búsqueda del sentido de la vida, mediante el análisis de textos para vincularlos con su entorno en el que sólo algunas mujeres son visibles.

- Creará textos tomando como modelo la minificción, el caligrama y/o haikú, entre otros, para generar una propuesta acorde con su realidad.

En estas primeras líneas, veremos que el currículum oculto se encuentra en el uso de las generalidades, más allá de las discusiones sobre lenguaje inclusivo que versan sobre la importancia de hablar de autores y autoras; el uso del masculino como genérico pierde este carácter debido a la mínima mención de mujeres en las propuestas de lecturas, y se da por entendido que casi no hay obras escritas por mujeres que puedan ser consideradas representativas en cuanto a las innovaciones literarias: el quehacer humano representado en la literatura es esencialmente masculino y las transformaciones sociales no incluyen a muchas mujeres.

En los contenidos conceptuales de esta unidad encontramos los objetivos específicos y se anexa en el punto 1.5 "Intenciones de la literatura: lúdica, crítica, social, política, entre otras". Considero que es muy importante la inclusión femenina en este rubro debido a que los temas propuestos se relacionan directamente con la cotidianidad de los alumnos en la que participan las mujeres, además de que debemos recordar que es justo gracias a la crítica feminista que muchos temas que antes eran de índole privada ahora forman parte de la agenda literaria. ${ }^{85}$ La omisión de textos escritos por mujeres lleva a una presentación parcial del mapa de la literatura nacional.

En cuanto a los contenidos procedimentales, las mujeres quedan fuera de los siguientes apartados: "Análisis y reflexión de los conceptos de realidad, ficción y verosimilitud en textos teóricos y literarios" e "Identificación y análisis de los recursos innovadores en algunos de los siguientes textos frente a la métrica tradicional".

${ }^{85}$ Cfr. Nattie Goluvob, La crítica literaria feminista. Una introducción práctica. 
Finalmente se habla de los contenidos actitudinales y considero que este es el punto en el que más evidente es que la omisión lleva a la desaparición.

1.11Valoración de los recursos innovadores estéticos, éticos e ideológicos de la poesía, la narrativa y el teatro. 1.12 Apreciación del compromiso del escritor ante la problemática de su entorno. 1.13 Estimación de la ruptura de valores establecidos para crear una propuesta literaria innovadora. 1.14 Valoración de la literatura como una expresión artística en contante transformación.

Si partimos de la premisa de Guadalupe Jover que dice que al omitir a las mujeres silenciamos a más de la mitad de la población, veremos que estamos fomentando la discriminación de género y que de manera imperceptible se repiten los patrones de exclusión. ${ }^{86}$

La unidad 2 lleva como título "La identidad nacional y la otredad". En esta unidad nuevamente encontramos la mención de cuatro mujeres: Sor Juana, Rosario Castellanos, Ana Lydia Vega y Lydia Cabrera, todas en el punto 2.5 "Selección y lectura de narrativa (mito, leyenda, crónica, novela, cuento), poesía y teatro que aborden los temas del indigenismo y la negritud".

Los objetivos específicos plantean que el alumno:

- Reconocerá la literatura escrita en su mayoría por hombres blancos o mestizos como vehículo de identidad nacional y cultural, a partir de la lectura de diferentes textos para concientizar los rasgos que lo definen como hombre occidental frente al otro hombre no occidental.

- Comprenderá los elementos de identidad mediante el análisis de la cosmogonía católica, la visión del mundo eurocéntrico, el lenguaje, la idiosincrasia y las tradiciones hetero-

\footnotetext{
${ }^{86}$ Guadalupe Jover, "Para que quepamos las mujeres habrá que cambiar los marcos”.
} 
patriarcales, en los textos literarios para relacionarlos con su ideología y su contexto en el que se conjugan todas las visiones tradicionales.

- Analizará la estructura y los elementos que conforman el ensayo, a partir de una lectura modelo para que identifique un texto de carácter argumentativo.

- Reflexionará de manera oral o escrita el tema de la otredad para manifestar su opinión con respecto a esta problemática.

En este punto, creo necesario detenerme para hacer énfasis en el tema de lo otro y de la identidad. Como lo vimos en el capítulo primero, uno de los elementos más importantes de los Estudios de Género es visibilizar aquello que es diferente. Considero fundamental integrar a esta unidad no sólo más textos de mujeres, sino textos de autores indígenas y no sólo de quienes hablan de lo indígena desde el centro. Experimentar la literatura como producto de lo humano y excluir a los indígenas y, en menor grado, a las mujeres, no es de ningún modo incluyente.

El otro elemento a cuestionar es la ambigüedad en cuanto a la palabra "problemática". Este elemento puede quedar a la interpretación del docente y dar cabida a gran variedad de prejuicios que no permitirían una reflexión individual. Es necesario plantear una serie de temas a discutir más específicos, como serían los diferentes contextos que existen en el país según la situación geográfica, la posición económica e incluso la realidad dependiendo del color de piel, la problemática de las ciudades, de los migrantes internos y las realidades en otras latitudes del continente. Con un poco más de guía, se podría enriquecer la discusión de esta unidad, y no dejarlo abierto a prejuicios del docente, sino considerando la opción de que el mismo profesor no tome en cuenta estas posibilidades que se pueden ligar de forma natural con los contenidos conceptuales de la unidad.

En cuanto a los contenidos conceptuales tenemos: 
- 2.1 Concepto de identidad y los elementos que la conforman.

- 2.2 Lo indígena y la negritud en la poesía y la prosa:

a) lenguaje: neologismos, regionalismos, indigenismos, negrismos;

b) figuras literarias: comparación, metáfora, imagen, difrasismo, paralelismo, aliteración;

c) ritmo y musicalidad;

d) narrador y personajes;

e) espacio y tiempo.

- 2.3 Elementos del ensayo

En este apartado, es importante incluir más bibliografía relacionada con la identidad y todos los elementos que la conforman. Comprender cómo se construye la identidad y las premisas que la construyen puede ayudar a que al adolescente que cursa el bachillerato y que se encuentra en la etapa en la cual "la personalidad del individuo adquiere el mecanismo psicológico básico de autorregulación y autocontrol, o sea, cuando se cristaliza la identidad de su yo" ${ }^{87}$ pueda entablar relaciones más claras ya que comprende los elementos que fundamentan la identidad.

Elaborar el concepto de identidad de forma que los jóvenes la entiendan es un reto especialmente en el contexto en el que estoy trabajando debido a que es necesario romper con una gran cantidad de paradigmas. Hay muchas formas de definir la identidad pero si la entendemos como

Una construcción que supone alienación y creación al mismo tiempo; necesarios para darle certeza al yo de lo que no es y, a su vez, inventar y creer lo que es, esforzándose por un pacto de reconocimiento con el mundo. Es resultado de una síntesis de imágenes, convocatorias, soluciones de compromiso, negociaciones psíquicas que a partir de un esfuerzo de sentido:

\footnotetext{
${ }^{87}$ Paola Elizabeth de la Concepción Zamora Borge, "La construcción de identidad en la adolescencia. El reto de apropiarse de un lugar en el mundo", p. 59.
} 
nomina, clasifica, distingue, reconoce, interpreta, interpela, crea sentido a las cosas del mundo brindándole al yo un lugar para sí. ${ }^{88}$

y reconocemos que uno de los medios que permite la construcción de esta compleja unidad de elementos es el lenguaje; veremos que es importante evidenciar cómo el currículum oculto se transporta en las palabras de forma subrepticia y se inserta en la composición de la identidad de los alumnos.

Es cierto que la identidad se construye principalmente en casa; sin embargo, la interacción social, los mensajes transmitidos por los medios de comunicación y todas las cuestiones actitudinales que forman parte del día a día de los alumnos, van a coadyuvar a que se entiendan y entiendan a los demás. Por esto considero indispensable integrar autoras y autores indígenas para romper con los estereotipos dominantes de la percepción social de México al menos desde la época colonial.

Otro elemento que forma parte de la identidad es la sexualidad, por lo tanto, en este punto, sería necesario incluir textos que permitan al menos abrir una ventana a las diversas formas de manifestación de la identidad sexual que vimos en el capítulo 1.

Finalmente, en los contenidos actitudinales encontramos:

2.10 Reconocimiento de los elementos que conforman la identidad.

2.11 Valoración del mundo indígena y la negritud.

2.12 Respeto a la diversidad cultural de México y de los demás países latinoamericanos.

En este último punto, nuevamente enfatizaré la falta de inclusión de autores indígenas contemporáneos y creo indispensable que se aclare el concepto de negritud, ya que siendo el

\footnotetext{
${ }^{88}$ Beatriz Ramírez Grajeda, "La identidad como construcción de sentido”, p. 196.
} 
programa de literatura mexicana e Iberoamericana se podría pensar en que se está incluyendo la literatura brasileña; sin embargo, considero indispensable anexar la existencia de los pueblos afromexicanos que habitan en la Costa $\mathrm{Chica}^{89}$, fomentar el respeto a los pueblos originarios de México así como evidenciar el problema de racismo que nos aqueja.

Para lograr esto, propongo que se revise el documental "Somos afromexicanos", proyecto de Extensión Comunitaria de la Universidad Autónoma Metropolitana, Unidad Iztapalapa, dirigido por Nadia Galaviz, quien entrevista a Tanya, psicóloga y activista afrodescendiente, quien cuenta su experiencia y explica las diferentes formas en que los mexicanos de origen negro son discriminados. "Sí, en pleno siglo XXI, en México se trata a las personas según el color de su piel. Esta es una realidad a la que se enfrentan indígenas y mestizos, pero sobre todo el millón y medio de personas afrodescendientes mexicanas que habitan en 12 entidades del país -destacan los estados de Oaxaca, Guerrero, Veracruz, Yucatán y Coahuila." ${ }^{90}$ A través de este documental se puede abrir el debate sobre la otredad dentro del territorio nacional, para después ampliarlo y, tal vez, ligarlo con la siguiente unidad en la que se tratará la relación del ser humano con otros seres vivos con la naturaleza.

La unidad 3, "El hombre y la naturaleza", integra a dos mujeres en los contenidos procedimentales: Alfonsina Storni y Rosario Castellanos. La primera aparece en el contenido 3.6 "Selección y lectura de textos poéticos relacionados con la naturaleza o el paisaje americano" y la segunda en el contenido 3.9 "Selección y lectura de textos narrativos relacionados con la naturaleza o el paisaje americano". Nuevamente, la omisión de mujeres en los demás contenidos lleva al cuestionamiento de si acaso no hay más escritoras mexicanas y latinoamericanas que utilicen

\footnotetext{
${ }^{89}$ Existen diferentes pueblos afromexicanos, $c f r$. Judith Solís Téllez, La construcción imaginaria de la identidad afromexicana. El caso de San Nicolás Tolentino, municipio de Cuajinicuilapa, Gro.

${ }^{90}$ Nadia Galaviz, "Somos afromexicanos".
} 
metáforas, símiles o prosopopeyas en sus escritos (contenido 3.7) o alguna de ellas no muestra en su escritura cómo es su relación con la naturaleza y cómo afecta su cotidianidad (3.11). Digamos que tanta omisión se traduce en una automática descalificación.

La unidad tiene como objetivos específicos:

- Reconocerá y comprenderá la importancia de los elementos de la naturaleza utilizados por los autores para identificar la configuración del entorno poético o del espacio a partir del análisis de diferentes textos literarios.

- Reflexionará e interpretará la influencia de la naturaleza en la vida del hombre público, no de la mujer en los espacios privados por medio de la lectura, y análisis de los textos literarios con el fin de percibirla como un espacio mágico desconocido, agreste, incontrolable, dominado por el ser humano hombre heterosexual.

- Creará un cuento, a partir de su experiencia lectora, para abordar el tema de la naturaleza y su influencia en la conducta humana.

- Identificará los diferentes tipos de argumentos a partir del análisis de obras representativas para comprender el discurso argumentativo.

En este caso, la unidad también brindaría un interesante espacio de reflexión, ya que hay muchos textos en los que la mujer es comparada con la naturaleza por proveedora, protectora y a la vez fuerte. Es una gran oportunidad para analizar estereotipos de género y roles que datan de tiempos ancestrales, así como costumbres de pueblos indígenas y la imagen de la mujer en distintas comunidades del país en relación con los espacios. Esta idea de la mujer como naturaleza lleva de forma obligada a la reflexión sobre el cuerpo femenino como dador de vida y sus diferentes representaciones en la literatura. En lo que se refiere a la perspectiva de género, el tema del cuerpo como naturaleza a dominar es una constante que data de los estudios feministas y que se ha 
retomado en la crítica literaria en varios textos; un ejemplo es el texto Strange Things: The Malevolent North in Canadian Literature en el que Margaret Atwood ${ }^{91}$ utiliza esta imagen para hacer un estudio del imaginario canadiense. Este es sólo una muestra de cómo se puede hacer un acercamiento crítico a la literatura partiendo de la imagen del cuerpo en relación con la naturaleza.

Los contenidos conceptuales son: 3.1 "Tópicos de la naturaleza en los textos literarios". 3.2 "Figuras literarias asociadas con el entorno natural: comparación, metáfora, antítesis, oxímoron, sinécdoque, hipérbole, prosopopeya, epíteto, aliteración, onomatopeya". 3.3 "La descripción de la naturaleza y su vinculación con el ser humano, como espacio mágico, agreste o dominado por el individuo". 3.4 "El cuento". 3.5 "Tipos de argumentos: de autoridad, personal, sentido común, analógico, entre otros". El análisis de la relación de la naturaleza con el hombre nos da una gran cantidad de temas de reflexión sobre la percepción de la mujer, del hombre y sus comparaciones con el sol, la luna y las diferentes construcciones culturales de la sexualidad en torno a estos temas, por lo que varias de las preguntas que se encuentran en el banco de posibles preguntas para reflexión que propongo en el siguiente capítulo los retoman.

Los contenidos actitudinales de esta unidad son: 3.14 "Apreciación de la importancia de la naturaleza en la conformación de la literatura mexicana e iberoamericana". 3.15 "Reconocimiento de la naturaleza como determinante de la conducta humana" y 3.16 "Valoración de la naturaleza como patrimonio del ser humano".

La unidad 4 se muestra como opuesta a la anterior ya que se llama "La ciudad literaria." En esta unidad, sólo se lee a tres mujeres y se encuentran en los contenidos procedimentales 4.6 "Selección y lectura de alguna de las obras narrativas propuestas". Las autoras propuestas son María Luisa Puga y María Fernanda Maquieira, quienes comparten escena con 26 autores hombres

\footnotetext{
${ }^{91}$ Margaret Atwood. Strange Things: The Malevolent North in Canadian Literature.
} 
en este mismo punto; por simple estadística, las posibilidades de que sean elegidas para la lectura son menores. La siguiente mujer mencionada es en el numeral 4.8, que dice exactamente lo mismo que el 4.6 citado con anterioridad. En este caso, es Elena Poniatowska y, al igual que en el caso anterior, comparte espacio con 12 autores hombres. No hay ninguna directriz específica para estos textos.

Los objetivos específicos de la unidad son:

El alumno:

- Comprenderá mediante la lectura de textos literarios de hombres que habitan en el espacio público, la ciudad como ficción que refleja una realidad social, que invisibiliza a las mujeres, política dominada por los hombres, histórica, económica y moral entendida desde el patriarcado, para tomar conciencia sobre el entorno urbano en el que se desarrolla la obra.

- Analizará el espacio literario percibido por hombres y sus diferentes ambientes como generadores de conceptos, imágenes, historias, formas de vida, registros lingüísticos, personajes y comportamientos filtrados por la visión masculina mediante la lectura de textos literarios para reflexionar y emitir opiniones sobre el panorama pesimista y optimista del contexto urbano.

- Redactará un texto argumentativo a partir del tema de la ciudad como pretexto para reflexionar sobre las problemáticas urbanas que no consideran las problemáticas a las que se enfrentan las mujeres.

En esta unidad, hay nuevamente una gran cantidad de temas que pueden servir para pensar desde una perspectiva de género la actividad de las mujeres en la urbe: ¿Cuáles son las actividades de los hombres? ¿Cuáles están reservadas para las mujeres? ¿En qué espacio aparece cada uno? ¿Con qué características se describen los personajes según el espacio, la función de los personajes, etc.? Este 
es un caso muy especial, ya que la ciudad es un espacio por lo general con grandes áreas públicas, en las que se ven a hombres y mujeres en un ambiente aparentemente más paritario, no obstante, no siempre ocurre así. Una forma de aproximación podría ser ver el video "Gender perspectives in urban planning"; 92 en él, se muestra cómo las actividades que se realizan dependiendo de los roles de género se encuentran directamente relacionadas con la forma en que se experimenta la vida en la ciudad y también permite ver que las ciudades, específicamente las rutas de transporte y las vías de comunicación, están diseñadas en función de las actividades designadas para los hombres y no para las mujeres, generando una forma distinta de percibir el espacio público que queda olvidado si no integramos estas lecturas en el programa. Con este marco, se puede hacer una aproximación distinta a los contenidos conceptuales presentados en esta unidad, que van a ser:

4.1 "El espacio urbano y su significación en la literatura: la verosimilitud del espacio físico" y 4.2 "La construcción del espacio: físico histórico, simbólico, psicológico, imaginario." En este punto existe una gran posibilidad de hacer una labor de transversalidad con otras materias, en especial con Historia y, al mismo tiempo, integrar la perspectiva de género a través de un análisis comparativo del espacio histórico de textos pertenecientes a periodos distintos y de la realidad del estudiante, haciendo énfasis en el rol de la mujer y del hombre en cada una de las narraciones, así como de las descripciones de espacios en los que se desarrolla la acción.

En continuidad con el punto anterior, el 4.3 plantea la descripción del espacio: lo público y lo privado. Como ya sabemos, este elemento es parte fundamental de los orígenes de la perspectiva de género, por lo que es un punto que no podemos desperdiciar para llevar a nuestros lectores a cuestionar cómo funciona la sociedad en cuanto a los espacios y las actitudes o habitus esperados

\footnotetext{
92 Ana Falú. Universidad de Córdoba.
} 
en cada espacio y por cada personaje, dependiendo de su género. Aquí vemos el punto 4.4 "El espacio y su vinculación con el personaje", mientras que el 4.5 es "El texto argumentativo".

En cuanto a los contenidos procedimentales, los primeros 3 son selección y lectura de obras de diferentes géneros, el 4.9 es la "Identificación y análisis de elementos literarios que conforman el espacio urbano en los textos leídos"; 4.10 "Identificación de imágenes (subjetivas-objetivas y simbólicas) narrativas- descriptivas, poéticas, teatrales del espacio representado"; 4.11 "Análisis e interpretación del espacio urbano en los textos leídos para vincularlos con el entorno social del alumno", y 4.12 "Redacción de un texto argumentativo en torno a una problemática urbana".

Por último, los contenidos actitudinales son: 4.13 "Valoración de las distintas formas expresivas y de la pluralidad de miradas que la literatura ofrece y su relación con el contexto" y 4.14 "Apreciación de la ciudad para promover el respeto, la conservación o la modificación de los espacios urbanos en función de la realidad social". Definitivamente, el tema de la ciudad da para integrar más miradas y diferentes realidades, así como para cuestionar la organización social, la gentrificación y, nuevamente, la discriminación por clase, género, raza y preferencia sexual. No obstante, me limitaré a presentar preguntas que se relacionen estrictamente con la perspectiva de género, ya que es el tema a desarrollar en este texto.

En la unidad 5, "El compromiso social y la denuncia”, nuevamente encontramos sólo tres mujeres y todas en el mismo numeral de los contenidos procedimentales que dice: "Selección y lectura de textos narrativos y dramáticos que aborden los temas: intolerancia, sistemas opresores y compromiso social (militarización, violación de derechos humanos, resistencia, solidaridad, desplazamiento de grupos humanos), considerando la particular historia de Hispanoamérica", y tenemos a María Luisa Bombal, Luisa Valenzuela y Elena Garro.

Los objetivos específicos de la unidad son:

El alumno: 
- Analizará obras literarias que hacen referencia a la intolerancia social y a los sistemas opresores, a través de la lectura de textos representativos, para perfilarlas como una denuncia de la desigualdad social, del ejercicio de la violencia y de las dictaduras latinoamericanas. Reflexionará e interpretará las características de esta literatura por medio de la lectura de textos y su contextualización histórico-política para identificar cómo surge la figura del sátrapa y cómo se manifiestan la denuncia y el compromiso social.

- Escribirá un ensayo literario por medio del análisis, la reflexión y la interpretación de la obra para fijar una postura, sólidamente argumentada, acerca de un problema social.

Considero que es indispensable integrar en esta unidad textos en los que se traten temas como las Abuelas de Plaza de Mayo, y las experiencias de mujeres que sufrieron, no sólo la pérdida de familiares, sino también la violencia a la que fueron expuestas. Podemos incluir en este punto algunas ideas críticas de la socióloga Rita Segato, quien ha realizado varios estudios en diferentes países de América Latina durante periodos de luchas internas y plantea la violencia de género ya no como un efecto colateral, sino como un arma. ${ }^{93}$ Estas ideas permiten enlazar la unidad anterior, con la idea de cuerpo y naturaleza, a esta como control de la sociedad a través del cuerpo de las mujeres. Otra posibilidad es integrar la imagen de aquellas mujeres aguerridas que luchan a la par de sus compañeros y que tienen funciones importantes en las organizaciones rebeldes, y hacer evidente el currículum oculto que se encuentra en los estereotipos de la mujer guerrillera en algunos textos en comparación con otros en los que el entorno violento lleva a la disolución de estereotipos de género y todos son igual de vulnerables, ya que el enemigo no distingue entre sexos.

Los contenidos conceptuales son:

5.1 Características de la poesía de compromiso social:

${ }^{93}$ Rita Segato, Foro CLACSO 2018. 
a) figuras literarias: comparación, ironía, simbolismo, analogías, descripciones, metáfora, imagen visual, auditiva, entre otras;

b) verso, rima, ritmo.

5.2 Narrativa y teatro de compromiso social:

a) estructura;

b) narrador y narratario en la novela y el cuento;

c) construcción del sátrapa y de otros personajes;

d) espacio y tiempo;

e) lenguaje: regionalismos, indigenismos, entre otros.

5.3 Influencia del contexto histórico-político en la configuración de la obra.

$5.4 \mathrm{El}$ ensayo literario.

Finalmente, en los contenidos procedimentales tenemos: 5.5 "Selección y lectura de poemas que aborden los temas de compromiso social"; 5.6 "Comprensión de figuras literarias, tipo de verso, ritmo, rima"; 5.7 "Análisis e interpretación de las constantes temáticas para identificar los problemas que cada autor denuncia"; 5.9 "Análisis del lenguaje y de los elementos constitutivos de la obra: estructura, espacio, tiempo, tipo de narrador, personajes (el gaucho, los negros, los indios, el caudillo, el dictador, el tirano, el jefe supremo, el restaurador, el regenerador, el generalísimo)"; 5.10 "Revisión de conceptos para reconocer sus implicaciones: dictadura militar, populismo, gobierno autocrático, despotismo, totalitarismo, absolutismo, entre otros"; 5.11 "Análisis e interpretación de las condicionantes sociales, económicas y políticas que propician los regímenes totalitarios y el compromiso social en los textos leídos"; 5.12 "Escritura de un ensayo literario, con argumentos sólidos, en los que plasme la postura de estudiante sobre algunos de los problemas analizados". 
Los contenidos actitudinales de la unidad son: 5.13 "Reconocimiento del compromiso social como uno de los grandes temas de la literatura mexicana e iberoamericana"; 5.14 "Valoración de los aspectos denunciados a través de la literatura"; 5.15 "Actitud crítica ante las denuncias contra la desigualdad social, el ejercicio de la violencia y de los sistemas opresores". En esta unidad, el tipo de pregunta se destina más a la generalidad y a tratar de mostrar cómo en momentos de peligro y de lucha se rompen muchas barreras y se construye una equidad que tiene como base la solidaridad y la búsqueda de un bien común, por lo que la considero de gran valor para fomentar una reflexión sobre la fragilidad de nuestros paradigmas y la forma en que se modifican o simplemente dejan de ser importantes dependiendo de las circunstancias en las que nos encontremos.

La última unidad, la unidad 6, se titula "La expresión literaria femenina”, y considero muy desafortunado el hecho de crear una unidad aparte, exclusiva para mujeres. Desde mi punto de vista, es una solución poco eficiente, separatista, que no ofrece una solución real y se puede equiparar a la creación de vagones exclusivos para mujeres en el sistema de transporte público y ese tipo de medidas que, pese a ser bien intencionadas y resolver de manera parcial algunas carencias, no atacan los problemas de raíz. Otro punto que no ayuda es la ubicación de la unidad. Se designa a la escritura femenina el último lugar en la distribución de contenidos; es la unidad sacrificable, aquella que se ve de manera fugaz por falta de tiempo, si es que se alcanza a tocar o simplemente no se puede revisar.

Nuevamente me encuentro en un campo complicado ya que parecería que me estoy contradiciendo en este momento. En la unidad de la ciudad argumenté la importancia de tomar en cuenta las necesidades específicas de las mujeres y podría decirse que para ello es necesario revisar sus necesidades de forma aislada, pero no es así, la intención de todo este texto es lograr una inclusión, no analizar a las mujeres como entes ajenos a la sociedad sino como parte de ella. Por lo 
que esta unidad mantiene la estructura de pensamiento patriarcal en la que las mujeres son parte de lo otro: son ajenas y no se incluyen, son segregadas y estereotipadas. A continuación, veremos cómo ocurre esto y que es parte de una mentalidad sistemática.

En este caso, no será necesario que especifique cuántas mujeres hay, ya que, además de que lo comenté al principio de este capítulo, es importante decir que no hay ningún hombre. Aquí surgen las preguntas: ¿no hay ningún autor que escriba sobre la situación femenina o que pueda ser leído desde esta perspectiva?, ¿no sería posible hacer una lectura de la figura femenina en contraste con un autor masculino y uno femenino? Es muy probable que en este caso alguien me critique por la intransigencia de exigir mayor inclusión y que me cuestione: “¿Qué más quieres? Ya hay una unidad sólo de mujeres. ¿Acaso no es suficiente inclusión?” Como lo mencioné en un principio, evidentemente, la intención de la unidad es resaltar el trabajo femenino; no obstante, lo que se necesita es la equidad, no la separación tajante que prima en el nuevo programa.

Los objetivos específicos de esta unidad son:

El alumno:

- Reflexionará sobre los elementos que constituyen la expresión literaria femenina y los Estudios de Género, a partir de la lectura de distintos textos y su análisis, para promover la equidad.

Mi pregunta aquí es, si lo que se busca es promover la equidad ¿por qué no practicarla desde la fundamentación del programa? Para este momento de la investigación, es evidente y hasta repetitivo que este objetivo queda fuera de toda perspectiva de género. Otro elemento que no ayuda es la idea de que la escritura femenina tiene características que la distinguen de la masculina. En el texto "Literatura escrita por mujeres", además de un maravilloso recuento de algunas de las autoras más representativas de la literatura mexicana, se hace referencia justo a lo complejo y a la vez desagradable del término "literatura femenina". Se explica cómo es que a principios del siglo XX 
Jorge Cuesta se refiere a esta forma de definir la literatura y concluyen que, para este autor, "definir una literatura como femenina suponía encerrar a la mujer en un criterio estético masculino. Son los hombres los menos indicados para determinar lo femenino de la literatura. Imposible pretender caracterizar, desde el grupo socialmente dominante, las manifestaciones de un sector en emergencia, como el de las mujeres escritoras." ${ }^{" 94}$ Vemos, pues, que ya desde hace un siglo este término está en duda, lo que me lleva a cuestionar la razón por la que se incluye en un programa aprobado un siglo después de que hubiera ya críticas a esta percepción de la literatura en México. Si acaso es una cuestión de currículum oculto en el que simplemente se plantea la opción y nadie la cuestiona porque se da por sentado que así son las cosas; encuentro mi propuesta aún más necesaria y a la vez me preocupa que dentro del grupo que trabajó en la elaboración del programa no haya habido un cuestionamiento al respecto. Con esto se evidencian las profundas raíces del sistema patriarcal en la sociedad y, por ende, en el sistema educativo.

Finalmente, concluiré remarcando que este tipo de aproximación no se acerca a las propuestas de los Estudios de Género y enfatizando la falta de bibliografía en el programa que apoye al docente o a los alumnos en la comprensión de los objetivos de los Estudios de Género, y que de ninguna manera se está fomentando la equidad, punto que he repetido a lo largo del análisis de estos objetivos, unidad tras unidad.

- Analizará e interpretará, mediante la lectura de textos, los temas, recursos y estrategias propios de la literatura femenina para reconocer el mundo desde la perspectiva de la mujer. Regresaré a algunos de mis comentarios previos en los que cuestiono si acaso las mujeres utilizan figuras retóricas y construcciones narrativas de forma única e irrepetible para los hombres o si, por el contrario, los hombres utilizan estos elementos y quedan vedados para los

\footnotetext{
${ }^{94}$ Armando Pereira, Claudia Albarrán et al, "Literatura escrita por mujeres".
} 
textos escritos por mujeres. El hecho de limitar ciertos temas a los textos escritos por mujeres es fomentar los roles de género y considerar que los hombres son incapaces de hablar de estos temas. Es decir, se hace el proceso opuesto, se limita la capacidad de creación de los hombres con base en los mandatos de género.

- Escribirá un ensayo académico por medio del análisis, la reflexión y la interpretación de la obra literaria para demostrar dominio de la argumentación y del uso del aparato crítico

Contenidos conceptuales:

6.1 Poesía escrita por mujeres:

a) métrica y figuras literarias;

b) temas: amor, desamor y erotismo, cuerpo, maternidad, soledad, masculinidad, equidad, violencia de género entre otros.

6.2 Narrativa y teatro escrito por mujeres:

a) la perspectiva del narrador en la novela y el cuento;

b) la construcción del personaje femenino;

c) los espacios y los ambientes;

d) temas: amor, desamor y erotismo, cuerpo, maternidad, soledad, masculinidad, equidad, violencia de género entre otros.

Me parece interesante la forma en que estos temas se encuentran enumerados ya que se manejan temas que han formado parte del trabajo de análisis literario desde quizá los inicios de este tipo de estudio y se deja al final tratar la masculinidad, la equidad y la violencia de género. Para hablar de estos temas se hace indispensable hablar de la diversidad sexual y considero que es una importante ausencia en los textos propuestos.

6.3 El ensayo académico. 
En los contenidos conceptuales se refuerza la premisa de que hay temas que son de mujeres y este tipo de planteamiento no refleja las premisas de los Estudios de Género y sí se acrecienta la posibilidad de integrar las ideas o prejuicios de género en lugar de permitir una crítica a éstos.

Contenidos procedimentales:

6.4 Selección y lectura de diferentes textos de poetas latinoamericanas que aborden el problema de género; 6.5 Identificación y análisis de los elementos formales de la poesía femenina (metro, rima, ritmo); 6.6 Reflexión sobre recursos y estrategias como ironía, parodia, ira, léxico cotidiano, intertextualidad, entre otros; 6.7 Interpretación del contenido de las obras seleccionadas a partir de los Estudios de Género en la literatura; 6.8 Selección y lectura de diferentes textos de narradoras y dramaturgas latinoamericanas que aborden el problema de género; 6.9 Identificación y análisis de los elementos formales de la narrativa femenina (estructura, narrador, personajes, tiempo, espacio); 6.10 Reflexión sobre recursos y estrategias tales como la ira, el humor, el lenguaje, al intertextualidad, el testimonio, entre otros; 6.11 Interpretación del contenido de las obras seleccionadas a partir de los Estudios de Género en la literatura; y 6.12 Redacción de un ensayo académico cuyo asunto gire en torno a un tema tratado por la literatura femenina utilizando de manera adecuada la argumentación y el aparato crítico.

Los contenidos procedimentales son consistentes con las observaciones previas: se mantienen los roles y mandatos de género, no hay una verdadera perspectiva de género que guíe el programa y falta bibliografía complementaria para el docente. Al igual que con la unidad de identidad, resulta muy ambiguo el término "problema de género" y sin una buena orientación se puede caer en una discusión que, en lugar de fomentar una reflexión positiva, lleve a la polarización dentro de la clase.

Finalmente, los contenidos actitudinales son: 6.13 Reconocimiento de los elementos que conforman el mundo femenino en la literatura y 6.14 Apreciación de la trascendencia de la 
literatura escrita por mujeres para promover un mundo más igualitario. Concluiré diciendo que esta unidad sí renueva el programa y propone la lectura de más mujeres; no obstante, no hay una aproximación con perspectiva de género y no proporciona temas que permitan una reflexión profunda sobre el estatus de las relaciones entre hombres y mujeres en la actualidad.

En cuanto a las sugerencias de trabajo, se plantea una forma muy tradicional. Pese a que se cita a Jover en la bibliografía, no hay un desarrollo de la metodología de las constelaciones. Nuevamente, el alumno queda como receptor y no se le ve incluido de forma activa; no se propone al profesor la posibilidad de escoger las lecturas con sus alumnos, sino que toda la labor de selección queda en manos del docente. Los puntos que he señalado anteriormente evidencian que mi investigación sigue siendo pertinente, tanto en lo que a la inclusión de la perspectiva se refiere, como a la propuesta didáctica.

Una vez que queda claro que hay algunas ausencias importantes en el texto y en la bibliografía del programa, se hace necesario que explique la forma de utilizar la propuesta de Jover y de Chambers en el aula para dar, como dice Jover, un protocolo de acción al docente. Antes, considero indispensable integrar a las autoras a las unidades para subsanar el asunto de la segregación por lo que el siguiente punto a tratar es la integración de las autoras, así como algunos autores, a las diferentes líneas temáticas en busca de una repartición más equitativa. 


\section{Capítulo III. Desarrollo didáctico}

\subsection{Propuesta de organización de autores}

Este último capítulo inicia con la propuesta de integración de las autoras de modo que no queden aisladas, sino que formen parte de la diversidad de temas de discusión grupal planteados en cada unidad. Para esta etapa de la investigación, primero seleccioné a las autoras mexicanas propuestas en la unidad seis y, de acuerdo con las características de sus obras más representativas, las reorganicé en el resto de las unidades. Cabe mencionar que incluyo a autoras que no están en el programa y en esos casos haré una nota al respecto, justificando su inclusión, así como textos de autores que sirven para reflexionar sobre temas de género. También en algunos casos hago propuestas de material no literario, dado que esto es congruente con la propuesta didáctica de Guadalupe Jover y es un medio de fomentar la lectura lúdica.

Uno de los primeros pasos que debemos seguir para conseguir nuestro objetivo de fomentar el carácter lúdico de la literatura es deshacernos de prejuicios sobre la alta y baja literatura, lo que es popular y lo que es considerado artístico; debemos recordar que nuestros alumnos tienen gustos diferentes a los nuestros y que necesitamos conseguir un genuino interés en las lecturas para que logremos introducirlos en el mundo de la literatura, y alejarse de estos prejuicios es un inicio en el que más tarde debemos profundizar para lograr una perspectiva de género.

En un momento inicial de este trabajo planteé la posibilidad de eliminar la última unidad e integrar a las autoras en las demás unidades; sin embargo, una vez que incluí a las autoras en las otras unidades, vi que la Unidad 6 sí es necesaria para integrar algunos contenidos formales relacionados con teatro y novela, así como varios de los temas de discusión. Lo que sigue siendo inaceptable es que sea una unidad exclusivamente de mujeres, ya que, en este sentido, pareciera que se da por sentado que el trabajo escrito por hombres se valida por adelantado; por lo tanto, no 
es necesario mencionarlos y que estas mujeres son excepcionales o, por el contrario, que las obras de teatro y novelas que tratan los temas mencionados sólo son escritas por mujeres. Con lo anterior quiero resaltar que la exclusión funciona en ambos sentidos: no sólo las mujeres son estereotipadas y segregadas, sino que también los hombres deben responder a esquemas marcados por los roles de género y justo esto es un ejemplo del currículum oculto. Supongo que el planteamiento de la unidad 6 buscaba hacer inclusiva la escritura femenina, pero logra el efecto ya mencionado que es una clara muestra de repetición de patrones de manera inconsciente. Dado lo anterior, propongo que la unidad 6 mantenga la temática planteada, pero con la integración de textos escritos por hombres para enriquecer la discusión; por lo tanto, es necesario cambiar el tema que guía la unidad, “La expresión femenina".

La integración de las autoras en las unidades quedaría de la siguiente forma:

\begin{tabular}{|c|l|}
\hline UNIDAD & AUTORAS \\
\begin{tabular}{|l|l|} 
1. Literatura y experimentación. \\
Poesía, Innovaciones de técnica \\
narrativa.
\end{tabular} & Elsa Cross \\
& Sor Juana Inés de la Cruz \\
& Elena Garro \\
& Margo Glantz \\
& Pura López Colomé \\
& Tedi López Mills \\
& Guadalupe Amor \\
& Coral Bracho \\
& Inés Arredondo \\
& María Enriqueta Carrillo \\
\hline $\begin{array}{l}\text { 2 La identidad nacional y la otredad. } \\
\text { Concepto de identidad. }\end{array}$ & Rosario Castellanos \\
Lo indígena, la negritud y la prosa. & Elena Poniatowska \\
& Laura Esquivel \\
& Esther Seligson \\
& Guadalupe Dueñas \\
& Documental “Somos afromexicanos". \\
& Documental Ciclón de Dolores. \\
& Jorge Miguel Cocom Pech \\
\hline 3 Tópicos de la naturaleza. & Amparo Dávila \\
Cuentos. & Dina Grijalva \\
& Elva Macías \\
& Miriam Moscona \\
& María Luisa Puga \\
\hline
\end{tabular}




\begin{tabular}{|c|c|}
\hline & $\begin{array}{l}\text { Sara Sefchovich } \\
\text { Carmen Boullosa }\end{array}$ \\
\hline $\begin{array}{l}4 \text { La ciudad literaria. } \\
\text { Lo público y lo privado. } \\
\text { Construcción del espacio físico y lo } \\
\text { histórico. }\end{array}$ & $\begin{array}{l}\text { Guadalupe Loaeza } \\
\text { Concepción Sada } \\
\text { Luis Zapata } \\
\text { María Luisa Puga } \\
\text { Salvador Novo } \\
\text { Condesa Calderón de la Barca } \\
\text { Cristina Rivera Garza } \\
\text { Carlos Monsiváis }\end{array}$ \\
\hline $\begin{array}{l}5 \text { El compromiso social y la denuncia. } \\
\text { Ensayo literario. }\end{array}$ & $\begin{array}{l}\text { Nellie Campobello } \\
\text { Bárbara Jacobs } \\
\text { Elena Poniatowska } \\
\text { Leonor Azcárate } \\
\text { Rosa Beltrán } \\
\text { Amalia Caballero de Castillo Ledón } \\
\text { Irma Pineda Santiago } \\
\text { Elisa Corona Aguilar }\end{array}$ \\
\hline $\begin{array}{l}6 \text { Narrativa y teatro. } \\
\text { Masculinidad, equidad, violencia de } \\
\text { género. } \\
\text { Erotismo, amor y desamor. }\end{array}$ & $\begin{array}{l}\text { Ana Bergua } \\
\text { Dina Grijalva } \\
\text { Luisa Josefina Hernández } \\
\text { Ethel Krauze } \\
\text { Concha Méndez } \\
\text { Aline Pettersson } \\
\text { Concepción Sada } \\
\text { Margarita Urueta } \\
\text { Sabina Berman } \\
\text { Coral Bracho } \\
\text { Hotel Juárez } \\
\text { Macario Matus } \\
\text { Briseida Cuevas Cob } \\
\text { Eduardo Antonio Parra } \\
\text { Enrique Serna } \\
\text { José Emilio Pacheco } \\
\text { Octavio Paz }\end{array}$ \\
\hline
\end{tabular}

De los autores que no están en el programa y que yo incluyo se encuentran: en la unidad 2, que trata sobre identidad nacional, Guadalupe Dueñas, quien en su texto Tiene la noche un árbol, muestra algunas características del humor nacional, así como costumbres y hábitos. También agregué dos documentales que hablan sobre la población afromexicana y algunas de sus historias. No hay mucha información sobre producción literaria de este grupo, pero sí se hace referencia a 
relatos que provienen de la tradición oral, que es un elemento sumamente importante tanto en la comunidad afrodescendiente como en varias comunidades indígenas. En este sentido, también integré a Jorge Miguel Cocom Pech, quien escribe en maya sobre la filosofía de esta cultura y la tradición oral, y sus textos han sido traducidos al español, náhuatl e inglés, entre otros idiomas. Su trabajo fue premiado por el Instituto Cervantes de Nueva York y su obra más conocida es Muk'ult'an in Nool (Secretos del abuelo). Es cierto que hay muy poca crítica literaria entorno a este narrador, pero no sería un caso excepcional, ya que varias autoras nombradas son muy recientes, por lo que no han sido muy estudiadas; no obstante, todas las propuestas mencionadas han recibido algún premio por su calidad literaria y es importante recordar que lo que buscamos conseguir es que exista variedad y que los estudiantes encuentren puntos de encuentro con los textos, por lo que se hace necesario recurrir a escritores y escritoras contemporáneos que de alguna manera comparten un mismo contexto con los alumnos para poder, poco a poco, introducir autores con los que no tienen tanta relación, pero que a través de la lectura puedan construir estas relaciones temporales que en muchas ocasiones ayudan a la identificación del lector con el texto y, en consecuencia, al disfrute. Asimismo, siguiendo las recomendaciones de Jover, en muchas ocasiones los autores contemporáneos pueden ser un poco más sencillos dada la cercanía lingüística con los estudiantes, y los autores anteriores resultan un poco más complejos. Con eso se comienza a elevar el nivel de dificultad de forma paulatina.

En la unidad 4, que tiene como tema la ciudad, integré autores que recorren de manera literaria la Ciudad de México. Incluyo a la Condesa Calderón de la Barca, quien no sólo describe la ciudad, sino que tiene un verdadero libro de viajes que nos permite conocer el México de finales del siglo XIX, sus costumbres, sus calles y hasta la forma de comer, siempre desde el punto de vista del otro; esto es importante para después poder ligar esta discusión con otros temas. Después tenemos a Salvador Novo, quien nos lleva por la Ciudad de México de mediados del XX e integra 
una visión más lúdica de su historia y permite vislumbrar una identidad de género diferente. Otro autor que considero pertinente es Luis Zapata, quien ilustra la ciudad de México de los años 80 . Del mismo modo, Carlos Monsiváis narra algunos momentos críticos de la vida de la ciudad y Cristina Rivera Garza nos lleva en narrativas más complejas por espacios urbanos que se combinan con espacios privados, lo que permite tener una gran variedad de estilos narrativos para tratar los temas propuestos en la unidad.

Para la unidad 5, únicamente incluí dos autoras: la primera es Irma Pineda Santiago, autora zapoteca que en su obra trata costumbres de su pueblo y denuncia las situaciones que enfrenta la población del sur del país. Considero que en esta unidad es imperioso integrar, no sólo a esta autora, sino buscar más escritores de la zona del sureste de México, ya que sin ellos no hay forma de tener una verdadera perspectiva del espacio cultural de la sociedad mexicana y no seríamos del todo incluyentes. La otra es Elisa Corona, quien incursiona en el género ensayístico y, precisamente, el tema a tratar en la unidad es el ensayo literario. Como lo comenté en el capítulo 2, la escritura no es una preocupación del sistema educativo nacional; por lo tanto, la creación de un ensayo literario me parece un objetivo fuera de la realidad alcanzable. No obstante, el ensayo que escribe esta autora sobre literatura infantil y juvenil es no sólo un buen ejemplo de ensayo literario, sino que trata obras y vocabulario conocido por los estudiantes de este nivel educativo, por lo tanto, es un medio amable y lúdico de incursión en el género.

Por último, propongo que el tema guía de la unidad 6 sea identidad de género. A través de esta línea podemos discutir todos los temas que se mencionan, como amor, desamor, violencia de género, erotismo, masculinidad y equidad. En esta parte, agregué varios escritores y un texto recopilatorio, Hotel Juárez. En la mayor parte de mis propuestas hago referencia a los esc ritoresy no a los textos, debido a que es posible trabajar la temática propuesta en varias de sus obras; en esta ocasión, menciono el texto, ya que, además de ser una recopilación, es exactamente éste el que 
considero indispensable trabajar. Hotel Juárez es una obra que se refiere a la violencia de género que se vivió en el norte del país y que muchas ocasiones no es del todo bien conocido ni en el centro ni en el sur, por lo que considero necesario incluirlo. Menciono a Macario Matus, escritor zapoteca que trabaja poesía, teatro y narrativa con una gran preocupación por el erotismo; Briseida Cuevas Cob es poeta maya y en su obra explora el papel de la mujer en la cultura maya del sur del país; Eduardo Antonio Parra tiene algunos cuentos en los que es posible analizar el rol de género y hacer preguntas sobre la masculinidad; Enrique Serna presenta varias obras de cuentos en los que podemos ver la construcción de la identidad sexual, los estereotipos y algunos rasgos de violencia de género en diversas situaciones y no sólo hacia mujeres. José Emilio Pacheco nos permite explorar las expectativas de nuestra sociedad en cuanto a los roles familiares y, por último, Octavio Paz explora el amor y el erotismo, permitiendo cuestionar la vigencia de algunas ideas en contraste con la actuales.

Una vez que he distribuido a nuestros autores y he agregado algunos, debo decir que no se logró una repartición completamente equitativa; para esto se requiere un trabajo de mayor envergadura que el que se puede realizar para una investigación de maestría, ya que es necesaria la lectura de una gran cantidad de textos. Más bien, creo que para alcanzar esta meta se necesita el trabajo de un cuerpo colegiado que pueda discutir con perspectiva de género la inclusión de autores y autoras a cada uno de los ejes temáticos. No obstante, sí es posible hacerlo, hay mucho material para lograrlo y para seguir con este texto presentaré el modelo de trabajo didáctico.

\subsection{Propuesta didáctica}

En este apartado, desarrollaré a detalle la secuencia didáctica para trabajar la inclusión de género. Ya en el capítulo dos mencioné los conceptos básicos, por lo que sólo retomaré lo necesario para especificar los pasos a seguir. Las formas de trabajo de Adaín Chambers y de Guadalupe Jover se 
fundamentan en las premisas del constructivismo, el cual sostiene que el conocimiento significativo es el que el alumno construye a través de la experiencia, por lo tanto, la socialización del texto en el aula es el medio elegido para llevar a cabo el trabajo literario. La interacción de los alumnos permitirá no solo la generación e intercambio de una gran variedad de ideas e interpretaciones, sino que por medio de la diversidad de comentarios, cada alumno llegará a sus propias conclusiones, tanto en lo referente al conocimiento de los contenidos formales del programa, como a la identificación de las ideas de género o del currículum oculto en los textos. Para lograr esto último, el profesor tendrá función de facilitador y seguiré a Adain Chambers para entender el proceso de socialización del texto y a Guadalupe Jover para construir el corpus de lecturas.

Chambers sostiene que la socialización del texto hace que lleguemos a una mejor comprensión y cita a Steve Bicknell, quien dice: "Nosotros no sabemos lo que pensamos sobre un libro hasta que hablamos de él." 95 El proceso de comprensión que se realiza al hablar de un libro no es lógico, más bien es guiado por las percepciones del lector y, por lo tanto, responde a su bagaje cultural y experiencias de vida. Si bien cada lector es diferente, el autor menciona que, dentro de una plática informal sobre un texto, generalmente se comparten las mismas cuestiones, aunque no forzosamente en el mismo orden: se comunica el entusiasmo, se habla de lo que gustó y no gustó de la lectura, de aquellas cosas que causaron desconcierto o dificultad.

A través de estas conversaciones y con la guía adecuada del docente, se puede lograr que los alumnos descubran patrones y todos aquellos elementos formales dictados por el programa indicativo. De la misma forma, por medio de preguntas especialmente formuladas se puede lograr que comparen un texto con otros para, así, llegar a una reflexión en torno a los temas que hayan sido elegidos por el facilitador para crear la sesión. Este tipo de trabajo coincide con los

\footnotetext{
95 Steve Bicknell citado por Adain, Chambers, "Dime", p. 19.
} 
planteamientos de los autores que se refieren a la transversalidad, ya que se fomenta el trabajo cooperativo, que es una ruta hacia el trabajo colegiado entre diferentes áreas. Uno de los valores que se ejercita en este tipo de actividades es la empatía, debido a que la intención es el escucharse a sí mismo, escuchar a los demás y reconocer nuestras diferencias.

En conclusión, a través de la discusión se puede lograr la inclusión de la perspectiva de género en el cotidiano escolar. Definitivamente, se necesita un facilitador preparado, con conocimientos tanto del área de literatura como de perspectiva de género y sus representaciones en las actitudes y expresiones diarias y en los textos.

El siguiente punto es la selección de textos. Como vimos en páginas anteriores, una de las premisas del programa indica que las lecturas deberán ser afines a los intereses de los estudiantes. Para lograr esto, la propuesta de lecturas no debe ser unilateral, ya que el facilitador/profesor no siempre va a conocer todos los entornos e intereses de sus estudiantes, por lo que es indispensable hacerlos partícipes de la selección de lecturas.

Si se busca fomentar el gusto por la lectura, no se puede imponer ningún texto, por lo que considero que la propuesta de crear constelaciones literarias es muy pertinente para lograr esta meta y, a la vez, la inclusión de la perspectiva de género. Una de las principales preocupaciones que motivan el trabajo de Jover es la necesidad de renovar el corpus "en función del lector al que va destinado, es decir, de su horizonte de expectativas y su competencia lectora y literaria."96 Para ello, propone la creación de "itinerarios" unidos por medio de diferentes líneas, ya sean temáticas, por los personajes, época, ámbito geográfico, género o subgénero. La base de la elección siempre debe estar perfectamente justificada y clara para el facilitador y los alumnos. Una

\footnotetext{
${ }^{96}$ Guadalupe Jover, Constelaciones literarias Sentirse raro. Miradas sobre la adolescencia, p. 11.
} 
vez seleccionados los textos, se escoge una constelación estelar para representarlos y se inicia la preparación del material.

El primer paso es diseñar lo que ella llama tráilers, que son fichas en las que se explica brevemente de qué se tratan las obras que van a formar la constelación. La selección de los textos debe llevar una seriación e ir incrementando la dificultad para hacer que los alumnos enriquezcan su competencia lectora. En este punto, para programas como el de Literatura universal, que aún se organiza de manera cronológica, me atrevería a recomendar iniciar el estudio de la literatura, no en el orden que se propone, sino comenzar por los textos del siglo $\mathrm{XX}$, porque son más cercanos a los alumnos en cuanto a temática y vocabulario. Este es un método utilizado en algunas carreras de literatura, justamente para que el alumno mejore sus capacidades lectoras y no se enfrente a un texto que pueda resultar frustrante. ${ }^{97}$ En el caso del programa analizado en este texto, esto ya no es necesario, la nueva organización permite tomar textos de cualquier periodo, lo que enriquece enormemente la gama de posibilidades y ayuda al profesor a definir los niveles de dificultad de los textos.

El paso tres es incluir textos no literarios en la constelación para fomentar la intermedialidad ${ }^{98}$ y la interdisciplina. ${ }^{99}$ Finalmente, Jover menciona que su objetivo es conjuntar o “conciliar” los diferentes retos que implica la enseñanza de literatura:

- la intervención (enseñar a leer literatura) y la libertad (ofrecer ocasión para la lectura placentera y autónoma, para la mera fruición).

\footnotetext{
${ }^{97}$ El programa de Lengua y Literaturas Modernas (Letras Inglesas) de 1975 inicia con el estudio de la literatura inglesa del siglo XX y retrocede hasta llegar a la literatura medieval. Ya que el vocabulario medieval es muy lejano al estudiante, así como las referencias históricas, se construye el conocimiento de manera inversa. Una ventaja que encuentro en esta propuesta es que se obliga a romper con el pensamiento lineal y se fomenta la formación de conexiones históricas diferentes a las acostumbradas por el cientificismo educativo. Algunas otras carreras en el Reino Unido utilizan este mismo método de organización.

${ }^{98}$ En este caso utilizaré el significado más amplio de intermedialidad que es "crossing of borders between media", el cruce de dos formas de expresión, por ejemplo, la literatura y el cine, la literatura y la pintura o la literatura y la música. Dos medios diferentes que expresan la misma historia.

${ }^{99} \mathrm{La}$ interdisciplina se refiere al cruce entre diversas disciplinas. Para poder hacer que exista transversalidad en un programa es necesario hacer trabajo interdisciplinario, es decir integrar la literatura con la biología, la geografía y las matemáticas para hallar los puntos en común y lograr la transversalización del currículum.
} 
- las lecturas comunes ("leer juntos") y los itinerarios personales.

- la necesidad de compartir un imaginario colectivo (como elemento que cohesiona a las sociedades), con la heterogeneidad y diversidad de las aulas (desde el origen cultural hasta el diferente grado de competencia lectora y literaria.) $)^{100}$

\subsection{Constelación literaria}

Para ejemplificar una constelación, decidí tomar un tema que no estuviera directamente relacionado con género para mostrar que en cualquier tópico se puede integrar esta perspectiva. Seleccioné la unidad 4, el tema es la ciudad literaria y la descripción del espacio: físico, histórico, simbólico, psicológico, imaginario.

Como ya lo comenté, lo primero es seleccionar los textos y para ello debemos conocer a nuestro público. Generalmente, uno como profesor conoce el tipo de población escolar con el que trabaja a través de la experiencia; no obstante, siempre es recomendable hacer una serie de dinámicas de clase que permitan conocer el bagaje cultural del grupo, sus expectativas, sus intereses y, sobre todo, sus gustos literarios. Para esto propongo juegos como adivina la película con mímica, en los que los alumnos deben realizar un intercambio y llegar a acuerdos en cuanto a textos conocidos por todos. Considero este tipo de aproximación más afortunado, ya que la pregunta directa generalmente recibe una respuesta pensada que pasó por el tamiz de la autocensura para evitar quedar mal ante su grupo o ante el profesor. Otros juegos útiles son los ahorcados, basta, etcétera. Se puede recurrir a la discusión grupal y a la lluvia de ideas que, generalmente, arrojan buena cantidad de datos, aunque siempre debe tener un fin específico para evitar que se dispersen demasiado.

Para este ejercicio, propongo al grupo ideal: son estudiantes de preparatoria de la UNAM, Ciudad de México, turno matutino. Su acercamiento a la literatura es más bien a través de libros

\footnotetext{
${ }^{100}$ Guadalupe Jover, Constelaciones literarias, p. 15.
} 
de literatura infantil y juvenil, son asiduos a las series y algunos leen cómics, manga o anime; probablemente haya algunos lectores de fans fics o escritores de blogs.

La constelación que elegí es Casiopea. No hay ninguna razón específica, quizá inconscientemente porque es una mujer, pero no por su historia en la mitología griega.

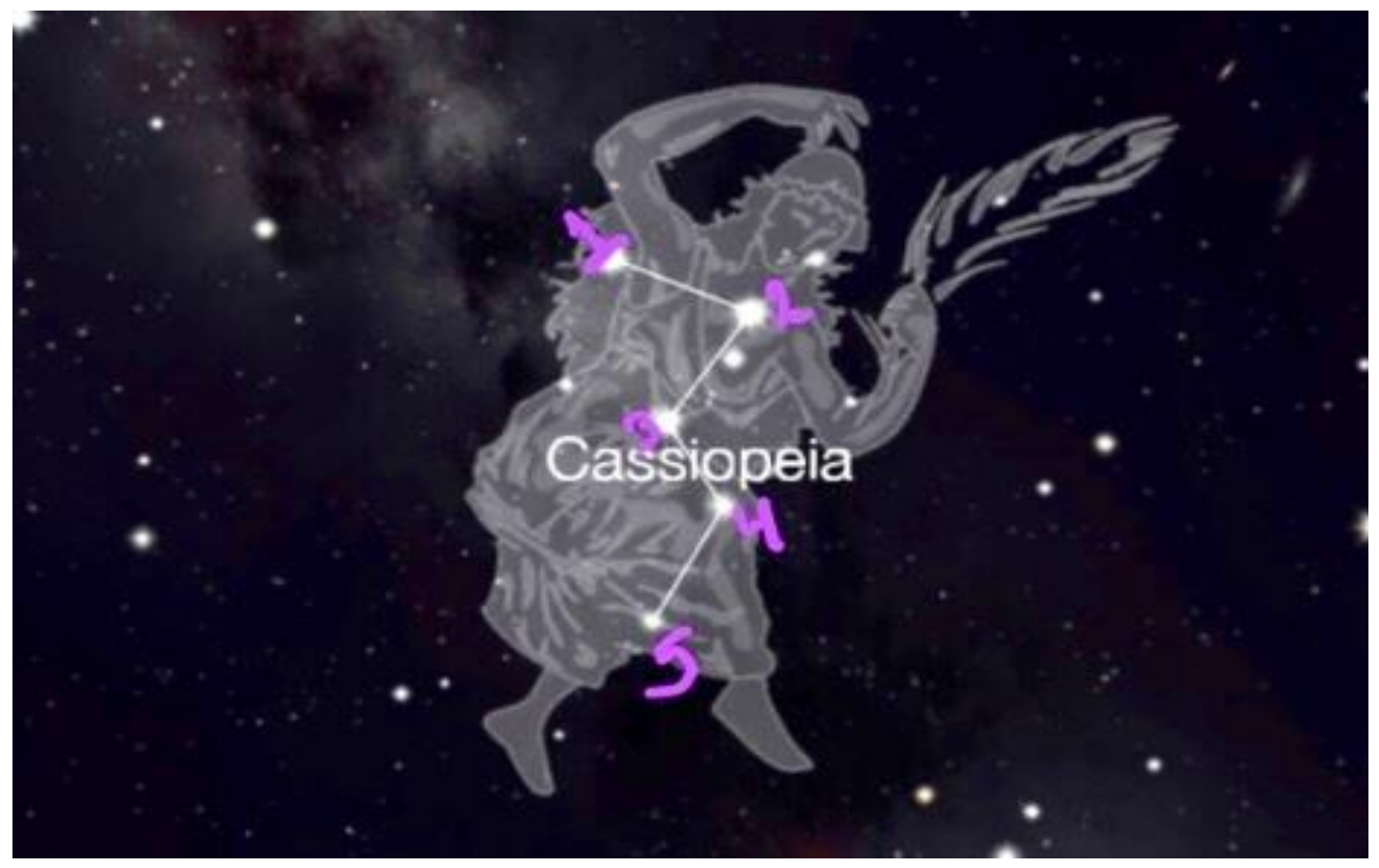

Los textos elegidos son:

1. Crónicas de Carlos Monsiváis publicadas en la revista Proceso.

2. Las Niñas bien de Guadalupe Loaeza.

3. Pánico o Peligro de María Luisa Puga.

4. El vampiro de la Colonia Roma de Luis Zapata.

5. La región más transparente de Carlos Fuentes.

En seguida se hace indispensable plantear los temas específicos a tratar a lo largo de la discusión en la constelación. Con esto me refiero no solo a los temas del programa, sino a los puntos entorno a los que debe girar el intercambio y los conocimientos que se espera sean adquiridos en el proceso. Esto es importante porque si no tenemos claros estos elementos, la elaboración de las preguntas detonadoras no será eficaz. 
Los contenidos que planteo están divididos en dos partes: la primera es la formal, relativa a los conocimientos sobre literatura, y la segunda, a lo relativo a la perspectiva de género. Pese a que aquí los presento de manera independiente, debo puntualizar que la idea es que se trabajen de manera integrada en la clase para que, a través de la socialización, se incluya la transversalización de género como currículum oculto; es decir, que por medio de las preguntas se fomente la reflexión sobre los roles de género establecidos y la construcción de estereotipos, sin mencionar la palabra género, para ir construyendo un pensamiento crítico al respecto.

\section{- Contenidos específicos de la constelación:}

$\diamond \quad$ La construcción del espacio: físico, histórico, simbólico, psicológico, imaginario

$\Rightarrow$ Elementos de la narración espacial

La ciudad verdadera, la ciudad narrada

Recursos descriptivos: adjetivos de forma, tamaño, color, textura, cantidad, etc. Iconización

Nombres referenciales

Lo general y lo particular

$\diamond \quad$ La descripción del espacio: lo público y lo privado

$\Rightarrow$ Descripción del espacio privado

Diferencia entre los espacios

\section{- Contenido de género de la constelación}

$\diamond \quad$ El espacio y los personajes

$\Rightarrow$ Espacios que ocupan los personajes

Quién describe los espacios

Adjetivos utilizados

Actividades en los espacios

\section{Tráilers}

Uno de los elementos clave en el modelo propuesto por Guadalupe Jover son los tráilers, éstos dan la oportunidad a los alumnos de entablar un primer contacto con el texto, de forma que les permita 
tener una idea previa de lo que van a leer. La función de éstos es similar a la de los que se hacen con las películas: permiten elegir la lectura, con lo que, a la vez, se respeta el derecho del lector a escoger. Muchos de los tráilers son reseñas, recomendaciones o videos; recurro a este tipo de medios audiovisuales ya que debemos tener presente que la función del tráiler es ser llamativo, por lo que el medio de entrega debe ser atractivo para los alumnos. A continuación, presento los correspondientes a las obras elegidas para esta constelación.

1. Crónicas de Carlos Monsiváis publicadas en la revista Proceso. En este caso, dado que muchos textos son cortos y uno de los tráilers habla de la obra del autor, es posible que alguno de los textos mencionados sea más atractivo para los alumnos que los propuestos por el profesor, por lo que la recomendación sería permitir la libre elección.

Para presentar a Carlos Monsiváis, seleccioné algunos cortos de entrevistas en las que podemos conocer su opinión y su forma de describir la ciudad. A continuación, enlisto los videos.

- Charlando con Cervantes - Carlos Monsiváis.

Es una entrevista en la cual se hace una breve descripción de varios de los textos en los que habla sobre la ciudad y permite a los alumnos escoger alguno. Por ejemplo, se habla sobre el libro de historietas recopilado por el autor.

https://youtu.be/RbhP6ZudmKY

- Tratos y retratos. La crónica y la ironía de Carlos Monsiváis. Ésta es una entrevista en la cual, durante los primeros minutos, se da un panorama general de la vida del autor.

https://www.youtube.com/watch?v=zPIKnoPGcFU

Hasta el minuto 3:18 


\section{Las niñas bien de Guadalupe Loaeza.}

- Tamara Delav. Reseña “Las niñas bien” de Guadalupe Loaeza. Esta es una bloggera que recomienda el libro. Considero que es una buena opción ya que da una buena descripción en el mismo tipo de lenguaje de los alumnos y puede invitar a la lectura. https://www.youtube.com/watch?v=WQid-X6ob1k

- Tráiler de la película Las niñas bien. Esta película está basada en los personajes de la obra de Loaeza. No obstante, si se decide utilizar este tráiler, sería recomendable cuestionar primero a los alumnos acerca de las diferencias entre los géneros y se puede aprovechar este espacio para fomentar la curiosidad sobre libros que no han leído y películas que sí conocen. En este caso, propongo algo muy similar a lo que mencioné durante el análisis del programa, ya que estoy convencida de que debemos partir de lo que los alumnos conocen. En muchas ocasiones, para ellos es más conocido el medio audiovisual que el texto, pero si aprovechamos los espacios que deja en la narración la adaptación, podemos generar curiosidad que lleve a los alumnos a leer el texto para satisfacer esos elementos.

https://www.youtube.com/watch?v=Zxz-idKlcRA

\section{Pánico o Peligro de María Luisa Puga.}

- Hay algunos casos en los que no hay material adecuado, por lo que el profesor tendrá que crear su propio tráiler. Por ejemplo, para este texto, el único recurso visual que encontré es una entrevista muy larga que habla del libro entre el minuto 12:37 y 13:58. Agrego el link de este material, ya que puede ser útil para el profesor, pero en realidad considero que no es del todo amigable con un público joven, por lo que propongo mi propio tráiler.

https://www.youtube.com/watch?v=F8MXzqr2rU0 
- Iniciar con una lluvia de ideas sobre la experiencia de los estudiantes sobre la avenida Insurgentes, preguntar si la conocen, qué partes han recorrido, dar datos como que la Ciudad de México es la única ciudad en el mundo que cuenta con una avenida que la cruza de sur a norte, pasando por el centro y que esta misma vía se convierte en la carretera Panamericana que cruza todo el país. Si es posible, se puede acompañar esta lluvia de ideas con una vista de calle de Google maps, con lo cual se logra un contacto del alumno con el tema y enseguida se puede dar inicio a la descripción de la autora y de la historia.

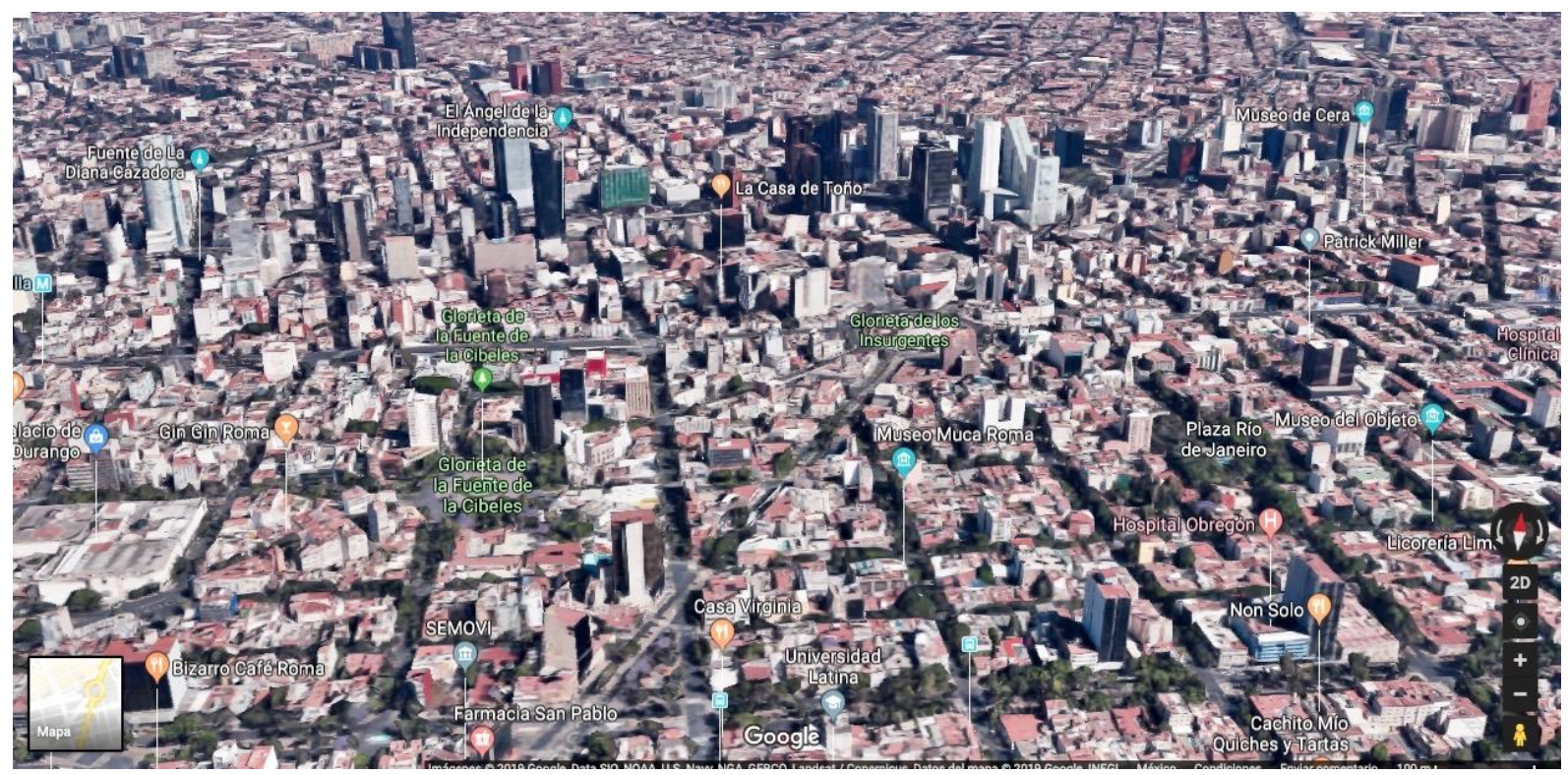

Este libro fue escrito durante la convalecencia de una cirugía de espalda de la autora y narra la historia de cuatro amigas y su recorrido sobre la Av. de los Insurgentes. La historia se narra desde el punto de vista de Susana, una secretaria que comparte con el lector su infancia y su periodo de adulto joven. Al principio parece ser una biografía más, pero la historia se va desenvolviendo y descubrimos que es más que eso. Tenemos a las cuatro amigas que poco a poco van desarrollando sus historias 
y sus personalidades, permitiendo que se cree una interesante trama que va más allá de lo esperado. Es como una serie narrada de una sola vez.

4. El vampiro de la Colonia Roma de Luis Zapata

- Tres trece! Reseña "El Vampiro de la colonia Roma de Luis Zapata”. En este video se hace una detallada recomendación del libro por parte de una bloggera de Mexicali, quien de manera simple y a la altura de los chicos, hace una buena reseña del texto. El video de esta lectora me parece mucho más cuidado que el de Las niñas bien y con más conocimientos literarios. No obstante, recordemos que la intención de estos fragmentos es generar la curiosidad en los alumnos, para lo cual no es necesario hacer una profunda crítica literaria, sino encontrar términos y elementos que sean afines a sus intereses.

https://www.youtube.com/watch?v=ZLtQ3u-snBY

- Otros elementos que podrían ser de utilidad para este texto es el uso de un mapa como el anterior, para mostrar a los alumnos la ubicación de la colonia Roma en la Ciudad de México y los barrios con los que colinda, las avenidas y calles, en combinación con algunas escenas de la película "Roma" de Alfonso Cuarón, en la que se muestran varias calles de esta colonia y se retratan de forma precisa muchos de los paisajes de la ciudad de los años 70.

- Contar a los alumnos que en esta historia se narran historias a veces cómicas y otras muy fuertes de miembros de la comunidad gay de la ciudad, que permite asomarnos a un mundo que por lo general no es divulgado, pero que está ahí todo el tiempo y que es parte de nuestro día a día, aunque no nos demos cuenta.

5. La región más transparente de Carlos Fuentes. 
- Producciones Volcán. Bajo la Región más Transparente/Primera parte. Este es un documental en dos partes, en el que se recorre la ciudad que describe el escritor en su novela; hay partes de entrevistas al escritor y sobre todo muchas imágenes de la ciudad. Recomiendo el uso de los primeros cuatro minutos, en los que se leen las primeras líneas del texto y al mismo tiempo se lleva a cabo el recorrido que se va narrando de manera visual.

https://www.youtube.com/watch?v=cBhToXq3au0

- Nuevamente recurro a un video de una blogger que hace una reseña del libro y lo recomienda de manera muy apasionada. https://www.youtube.com/watch?v=wjfWqbuVIhg

Los tráilers deben ser vistos en clase y discutidos en grupo, con la finalidad de ir generando nuevas constelaciones a partir del reconocimiento de temáticas precisas y ver si los alumnos hacen referencia a otros textos que hayan visto o leído; es decir, intentar que se comiencen a gestar los textos bisagra, que es así como Jover llama a todos aquellos textos que van a servir para iniciar una nueva constelación.

\section{Discusión}

Una vez que cada alumno ha elegido el texto que va a leer, se hace necesario organizar la discusión. Propongo que se divida el grupo en equipos por texto; la idea es que los alumnos puedan hablar sobre una experiencia compartida, por lo tanto, es necesario que todos los miembros del equipo hayan leído el mismo texto. Chambers propone que la discusión debe ser como las conversaciones coloquiales, en las que lo primero que se comenta es qué gustó y qué no; así que la primera pregunta a plantear en el grupo es si el texto cumplió con las expectativas creadas por el tráiler, si les gustó, 
qué partes de la historia gustaron más y por qué, y definir las partes que no fueron agradables y por qué.

Es importante tomar en cuenta que la discusión no es sistemática, es decir, no van a hacerlo en el orden que se plantea aquí. Es muy posible que se hable de qué sí gustó y después se comience a hablar de la anécdota y no de los temas que trata el texto. Lo que se busca es llegar a una reflexión sobre los temas, pero que no sea de forma académica, sino que se desarrolle naturalmente a través del intercambio de ideas. De los elementos que Chambers más defiende en su trabajo es el hecho de que al hablar se escucha, no sólo a los demás, sino a uno mismo y durante este acto es cuando llegan nuevas ideas que se alimentan de las distintas opiniones que hay alrededor.

La técnica didáctica que propongo es iniciar con una conversación por equipos en la que los alumnos compartan su experiencia lectora de forma natural, sin censura, guiada por el facilitador con preguntas de orden general: si les gustó la obra o no, por qué, si les recuerda a otra, que hagan una síntesis de la trama, si conocen alguna otra obra que tenga la misma trama (en este caso la obra puede ser una serie, película, cómic, novela o cualquier experiencia de los alumnos), qué no les gusto y por qué. Si es posible, en la misma clase, se propone realizar trabajo en equipo guiado por preguntas específicas del facilitador que lleven la reflexión hacia los objetivos del programa; por ejemplo, comenzar a preguntar si les gustó la forma en que se describe la ciudad, si conocen algún punto, qué partes de la ciudad que se mencionan en su texto conocen, sus experiencias o qué saben de las zonas mencionadas en el texto, qué pasa en cada lugar, qué lugar les parece mejor descrito y por qué, si les parece que los espacios se relacionan con los personajes, si hay personajes que sólo aparecen en un espacio físico, si hay características de los personajes que se relacionen con el espacio, si hay vocabulario específico para cada lugar, que características tiene cada lugar, etcétera. 
En este punto se puede comenzar a integrar la perspectiva de género a través de preguntas que hagan énfasis en la construcción de los roles de género, en las obras y su permanencia en nuestros días: ¿Cómo se representa a los personajes femeninos? ¿Cuáles son las características de los personajes masculinos? ¿Estas características, en otro texto conocido por los alumnos, son vigentes? ¿Cuál es la función del personaje femenino? ¿Es causante de la acción o es parte de la acción? (Aquí se puede utilizar la propuesta de las esferas de acción de Propp).

En este apartado, integraré una serie de preguntas que se le pueden hacer al texto, con las que se busca que los alumnos reflexionen sobre la perspectiva de género en las obras. Mi propuesta es que estas preguntas se mezclen con aquellas que se refieren al carácter formal del texto. En este caso, las pongo por separado por practicidad, no obstante, en la práctica se requiere que estén integradas a la discusión general.

- ¿Cuántos personajes hay?

- ¿Quién es el personaje principal?

- ¿Hay personajes femeninos?

- ¿Hay personajes de otra raza en el texto?

- ¿Hay algún personaje de la comunidad LGBTTI?

- ¿Cuántos personajes son hombres y cuántos son mujeres?

- ¿Qué actividades tienen los personajes masculinos?

- ¿Qué actividades tienen los personajes femeninos?

- ¿Qué características físicas tienen los personajes masculinos?

- ¿Qué características físicas tienen los personajes femeninos?

- ¿Los personajes se parecen a alguien que conozcas?

- ¿La forma de actuar de los personajes es congruente con lo que tu esperarías de ellos? 
- ¿En qué espacios físicos aparecen los personajes masculinos?

- ¿En qué espacios físicos aparecen los personajes femeninos?

- ¿Hay alguna relación entre el espacio y las actividades específicas de cada personaje?

- ¿Has visto personajes similares en otros textos, películas, animes, historietas etc.?

- ¿Qué características comparten los personajes que conoces y los de este texto?

- ¿Sabes qué es un estereotipo?

- ¿Crees que hay estereotipos en este texto?

- ¿Las personas que conoces entran en algún estereotipo?

- ¿Crees que los estereotipos son útiles para la lectura?

- ¿Crees que los estereotipos que vemos en los textos, tv, animes, etcétera influyen en nuestra forma de ser y ver el mundo?

En otra sesión, los alumnos elaborarán un cuadro sinóptico con los resultados de su discusión. La discusión versará sobre las características de los textos. Recordemos que éstas serán las respuestas a las preguntas planteadas por el facilitador, con el fin de que el alumno logre deducir los temas y la importancia del espacio físico en cada texto y hable sobre la perspectiva de género.

En una sesión posterior, los alumnos prepararán un resumen para sus compañeros; puede ser una representación o una explicación gráfica de la obra que leyeron y, finalmente, la expondrán con sus opiniones. Se puede terminar o ampliar esta constelación hasta la creación de un proyecto objeto o la escritura de una breve historia en equipos. El secreto siempre será el tipo de cuestionamientos que se planteen a los alumnos y la preparación de las diferentes partes de la clase.

Este tipo de clase conlleva mucho trabajo por parte del docente y la inclusión de la perspectiva de género depende mucho de la formación que el facilitador tenga al respecto, lo que nos remite a una de las dificultadas mencionadas en el principio de este capítulo, ya que 
dependemos del arraigo de los paradigmas y del manejo del currículum oculto que tenga quien guíe las actividades. Por esto, para completar cualquier propuesta de integración de género en el salón de clase, siempre será necesario trabajar de manera cercana con los profesores.

\section{Conclusiones}

Durante la elaboración de este texto, ocurrió una serie de eventos violentos que reforzaron la idea de urgencia en cuanto a la inclusión de género en las aulas. El primero fue el asesinato de dos niñas en el Estado de México: una niña de entre tres y cinco años fue abandonada en las calles de Ciudad Neza con signos de violencia sexual de la cual no se conoce el nombre y simplemente se le nombró “calcetitas rojas". ${ }^{101}$ El otro caso es el de Fátima, una adolescente de secundaria violada y asesinada por tres vecinos a escasos 20 metros de la puerta de su casa. ${ }^{102}$ Un tercer caso es la detención de una pareja que se dedicaba a asesinar mujeres, ${ }^{103} \mathrm{y}$, por último, el mapeo de la violencia de género realizado por María Salguero, quien se ha dedicado a registrar los feminicidios y actualiza el mapa de manera regular - un esfuerzo individual de una ciudadana preocupada- ${ }^{104}$ y los intentos de secuestro en los alrededores de las estaciones del metro en la Ciudad de México. ${ }^{105}$

Si bien éstos no son casos aislados ni los únicos, sí son los que, por el manejo mediático, se convirtieron en emblemáticos de la violencia de género y son una muestra de su aumento. Por ello, considero que la pertinencia de este trabajo es más que vigente y no sólo con lo que menciono en mi texto como justificación, sino que con la cotidianidad se hace evidente la necesidad de modificar nuestra aproximación a la perspectiva de género. Como lo dije en un primer momento, no creo que

\footnotetext{
${ }^{101}$ Carlos Vargas. ¿Quién es la niña de las calcetas rojas?

${ }^{102}$ Abusaron de Fátima, la apuñalaron 90 veces y dejaron caer una piedra en su cabeza. I

${ }^{103}$ Alberto, Najar. "monstruo de Ecatepec": qué se sabe de los asesinos seriales de mujeres que vendían los restos de sus víctimas en México.

${ }^{104}$ Gabriela Castillo. Una sola mujer hace el mapa más detallado de feminicidios en México.

${ }^{105}$ Mapa de ataques en el metro de la ciudad de México..
} 
la sola inclusión de una nueva visión en una materia cambie la situación de violencia actual, ni que sea la solución mágica a nuestros problemas; no obstante, considero que, dado que éste no es un problema exclusivo de México, sino que es una crisis mundial, debemos trabajar todos desde nuestras trincheras. Esta propuesta es un granito de arena para contribuir a la disminución de la violencia a través de la educación y de la reflexión sobre los cambios en la sociedad.

Los cambios siempre generan reticencia e incredulidad y van acompañados de dudas y, sobre todo, de miedo. La integración de nuevos elementos no es fácil y de ninguna manera es bien recibida, especialmente en el campo de la educación. Sin embargo, debemos aceptar que el Plan de Estudios de la ENP requiere una urgente actualización para cubrir las necesidades de la sociedad. Después del análisis realizado, queda de manifiesto que es necesario replantear la forma en que se piensa la inclusión femenina en el programa y que falta trabajo en cuanto a la idea de transversalización.

Justo hoy que me encuentro escribiendo las conclusiones de este trabajo, llegó a mis manos el programa actualizado de bachillerato de la SEP y me encontré con que en lo que a transversalidad se refiere, la DGB hace un ejercicio con biología y geografía por medio de un apartado que lleva por título "Plan de vida", en el que de manera explícita se tratan temas de sexualidad, reproducción y su relación con las materias que se están llevando en ese año escolar, de forma que las discusiones sobre género pueden entrar en este segmento de forma natural.

Considero que debemos crecer junto con nuestros estudiantes y entender que aquellos temas que antes no se mencionaban de forma específica, ya son conocidos para nuestros alumnos y normalizarlos en la discusión contribuiría a un cambio en la perspectiva de la violencia. Siempre he pensado que un error garrafal de la educación en México es tratar a nuestros estudiantes como si fueran inocentes o a veces hasta tontos; debemos considerar el entorno social y aceptar que se enfrentan a realidades diferentes a las nuestras. Como ejemplo, creo que es suficiente mencionar 
que, en México, 69 de cada 1000 adolescentes entre los 15 y 19 años son madres, ${ }^{106}$ por lo que temas como violencia de género y sexualidad deberían tratarse desde edades más tempranas. Es decir, debemos promover un cambio significativo en todos nuestros programas de estudios.

Como docente, estoy muy consciente de que la propuesta didáctica que hago requiere mucho trabajo de preparación, conocimientos sobre género y, sobre todo, tiempo, elemento que a veces no está disponible debido a las diversas situaciones laborales que enfrentan los profesores, especialmente los de la ENP. Sin embargo, considero que es necesario replantear nuestra práctica e incorporar nuevas propuestas de trabajo que no sólo cumplan con las perspectivas de los planes de estudios, sino que nos permitan que el pensamiento crítico de los alumnos sirva para la cotidianidad y los lleve a cuestionar más allá de los textos leídos en clase, que sean capaces de cuestionar su entorno y se replanteen sus paradigmas.

Para lograr lo anterior, es necesaria una práctica más personal, una en la que el alumno logre una relación más íntima con el texto y las propuestas de Chambers y Jover en conjunto logran que esto suceda, pues "al llevar nuestro propio mundo al mundo del texto y compararlos, descubrimos significados en uno u otro, o en ambos." 107

En cuanto a la organización de las autoras en el programa, quiero agregar que la necesidad de redistribuir a las escritoras en las diferentes unidades es indispensable, debido a que la inclusión de género nunca puede partir de la segregación. Un planteamiento así es per se una antítesis, ya que parte del principio de la diferencia y no de la equidad. Por lo tanto, una organización como la que hay actualmente no está acorde a la perspectiva de género y más bien abre una brecha en la percepción del estudiante.

\footnotetext{
106 Eva O. Arceo-Gómez, Raymundo M. Campos-Vázquez, "Teenage Pregnancy in Mexico: Evolution and Consequences".

${ }^{107}$ Chambers, op. cit., p. 19
} 
Finalmente, quiero agregar que mi trabajo recibió muchas críticas, una de ellas quizá la más machista, fue algo como lo siguiente:

¿Para qué sirve un trabajo en el que se incluya una perspectiva de género, y para qué incluir más mujeres si ya tienen los suficientes derechos y para qué pelear más si tienen muchos privilegios como que pueden entrar a centros de diversión nocturna sin pagar y pueden utilizar sus cuerpos para alcanzar mejores puestos y con que se vean bien es suficiente para que las tomen en cuenta, qué más quieren? También quieren que ahora se lea lo que escriben igual y ni lo hacen bien.

El hecho de que la cosificación de las mujeres en la vida social y la sexualización en el ámbito laboral sean considerados privilegios, hace evidente la gran necesidad de educar a las nuevas generaciones y explorar formas de tratar estos temas que, pese a que los avances, son completamente nuevos: no hay antecedentes en la vida de la humanidad de un cambio de paradigma tan grande como la percepción del género. La realidad es que nos enfrentamos a una serie de fenómenos que aún no comprendemos, pero que debemos analizar y tratar de incluir en nuestras vidas, por lo que considero que todo trabajo que busque entablar un diálogo sobre estos temas será una nueva ventana que permita la entrada de luz en un espacio aún oscuro. 


\section{Apéndice}

\section{Plan de Estudios de la Escuela Nacional Preparatoria Analítico}

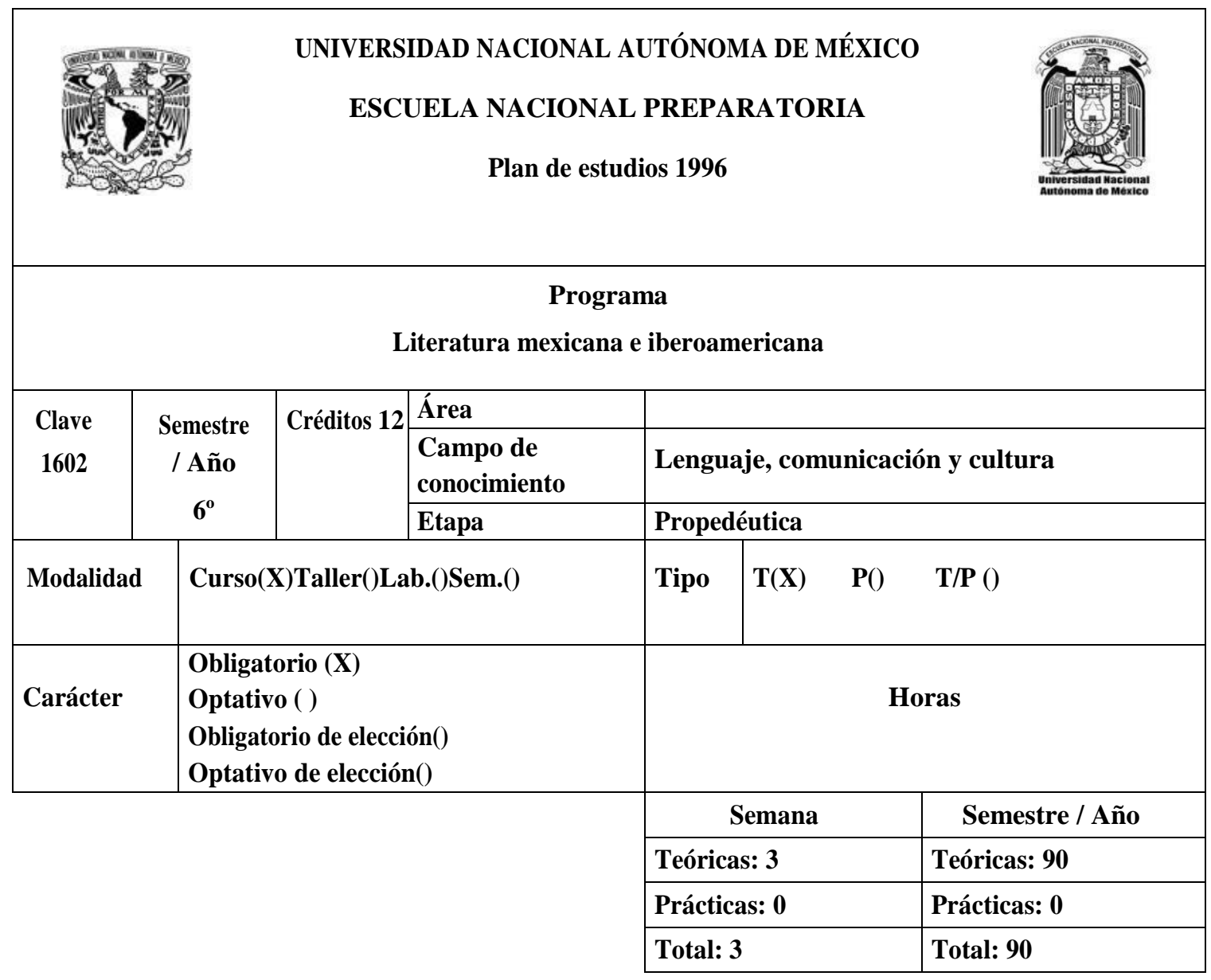

\begin{tabular}{|l|c|}
\hline \multicolumn{2}{|c|}{ Seriación } \\
\hline \multicolumn{2}{|c|}{ Ninguna ( ) } \\
\hline \multicolumn{2}{|c|}{ Obligatoria (X) } \\
\hline Asignatura antecedente & Literatura Universal \\
\hline Asignatura subsecuente & Indicativa ( ) \\
\hline \multicolumn{2}{|c|}{} \\
\hline Asignatura antecedente & \\
\hline Asignatura subsecuente & \\
\hline
\end{tabular}

Aprobado por el H. Consejo Técnico el 13 de abril de2018 


\section{PRESENTACIÓN}

La asignatura de Literatura mexicana e iberoamericana tiene como propósito general que el alumno profundice en la competencia literaria, la cual se entiende como la capacidad de comprensión y producción de textos literarios, lo que permitirá al alumno desarrollar su sensibilidad estética mediante la lectura, la apreciación y la interpretación de obras literarias de autores mexicanos e iberoamericanos, así como ser consciente de las problemáticas sociales; todo lo anterior con el fin de fortalecer, integrar y aplicar los conocimientos, valores y actitudes de las distintas disciplinas humanísticas que reúne el Plan de Estudios del bachillerato de la UNAM.

Este curso busca hacer del alumno un lector competente y autónomo, por ello el programa, en concordancia con el de las asignaturas de Lengua española y Literatura universal, continúa con la competencia literaria como eje para centrar al estudiante en la comprensión, en el análisis, en la interpretación y en la producción de textos. Cada unidad atiende un tema eje propio de la literatura mexicana e iberoamericana que agrupa varias obras de autores reconocidos. Como método de trabajo se sugiere la construcción de constelaciones literarias con la propuesta de autores y obras sugeridos. Una constelación literaria (Jover, 2009) puede estar integrada por obras alejadas entre sí en el espacio o en el tiempo, pero que abordan una cuestión temática relacionada con la condición humana, o aprovechan un mismo procedimiento narrativo, o bien están ambientadas en un mismo lugar o en una misma época. El único requisito necesario en el diseño de una constelación es hacer explícitos los criterios que vinculen una obra con otras. De cada constelación, el profesor elegirá el o los textos que considere pertinentes para cubrir los objetivos específicos de cada unidad; de igual manera puede centrarse en uno o más géneros.

Al finalizar el curso, y con ello el bachillerato, el estudiante será un lector autónomo y con un amplio panorama de la literatura mundial, lo que contribuirá a su formación humanística y al desarrollo de una postura crítica, comprometida ante las situaciones planteadas en los textos leídos pues, como señaló José Emilio Pacheco, "No leemos a otros: nos leemos en ellos". No está de más añadir que abordar la literatura mexicana e iberoamericana es importante, dado que ningún panorama de la literatura universal estaría completo sin sus aportaciones y visión del mundo. Por otra parte, leer textos en lengua materna propicia tanto la reflexión de su uso como de sus posibilidades estéticas.

En la escritura, el grado de complejidad aumenta sustancialmente en sexto año, pues el alumno trabajará el texto argumentativo; para ello partirá de la identificación de la estructura, del reconocimiento de argumentos y finalizará con la producción de ensayos literarios y académicos que incluyan tanto una argumentación fundamentada, surgida a partir del proceso de investigación, como un aparato crítico estructurados correctamente. En cuanto a la escritura creativa, se busca que el estudiante profundice en las formas y recursos del texto lírico y narrativo, utilizando como modelo obras mexicanas e iberoamericanas de escritores de econocido prestigio que, al mismo tiempo, despierten su creatividad e interés por la producción literaria. 
El programa está organizado en seis unidades cuyo estudio redundará también en el fortalecimiento de valores éticos del alumno. La primera unidad aborda la experimentación tanto de forma como de fondo que han transformado a nuestras letras a lo largo de los siglos; la segunda, tercera y cuarta unidad abordan los temas que han sido ejes rectores en la literatura: el estudio de lo nacional y de la otredad, el hombre y la naturaleza, la percepción de la ciudad y, por último, el compromiso social que incluye la postura crítica del escritor ante la realidad mexicana e iberoamericana; en la sexta unidad se abre un espacio a la literatura escrita por mujeres en un afán de promover la equidad de género.

Estudiada de esta manera, la disciplina contribuye a la formación del perfil del egresado, pues privilegia la literatura como vehículo de formación ética y humanística y permite el desarrollo del pensamiento crítico mediante la sensibilización, el análisis y la interpretación de textos; en tanto que la escritura se trabaja en dos vertientes, como construcción de textos argumentativos con toda la formalidad que se requiere y como producción literaria para fortalecer las capacidades creativas de nuestros estudiantes.

\section{Objetivo general}

La asignatura de Literatura mexicana e iberoamericana tiene como objetivo general que el alumno lea, comprenda e interprete obras representativas latinoamericanas, a partir del análisis y la producción de textos que contribuyan al fortalecimiento de su identidad, a su formación humanística, al pensamiento crítico y al goce estético.

\section{Unidades y número de horas}

Unidad 1. Literatura y experimentación

Número de horas: 15

Unidad 2. La identidad nacional y la otredad

Número de horas: 15

Unidad 3. El hombre y la naturaleza

Número de horas: 15

Unidad 4. La ciudad literaria

Número de horas: 15

Unidad 5. El compromiso social y la denuncia

Número de horas: 15

Unidad 6. La expresión femenina

Número de horas: 15

\section{Descripción por unidad}

Unidad 1. Literatura y experimentación Objetivos específicos

El alumno:

- Reflexionará sobre las innovaciones de forma y fondo en los textos literarios a través de la lectura de obras representativas, para ubicar la literatura como quehacer 
humano en constante transformación.

- Comprenderá las transformaciones artísticas y sociales, su relación con sentimientos de angustia, de vacío o de ironía, así como la búsqueda del sentido de la vida, mediante el análisis de textos para vincularlos con su entorno.

- Creará textos tomando como modelo la minificción, el caligrama y/o haikú, entre otros, para generar una propuesta acorde con su realidad.

\section{Contenidos conceptuales}

1.1 Realidad, ficción y verosimilitud

1.2 Transformaciones de la poesía: poemínimos, caligrama, haikú, poesía en prosa, entre otros:

a) la métrica tradicional frente a las rupturas de la forma

b) figuras literarias: imagen, metáfora, metonimia, sinécdoque, ironía, sinestesia, entre otras

1.3 Innovaciones de la técnica narrativa: estructura, juegos temporales y espaciales, tipo y punto de vista del narrador, monólogo interior

1.4 Teatro experimental (estructura: actos, escenas, cuadros, acotaciones; trama - dentro y fuera del escenario_- ; temas; personajes; lenguaje; interacción; improvisación)

1.5 Intenciones de la literatura: lúdica, crítica, social, política, entreotras

\section{Contenidos procedimentales}

1.6 Análisis y reflexión de los conceptos de realidad, ficción y verosimilitud en textos teóricos y literarios: Lauro Zavala, Teoría de los cuentistas; Mario Vargas Llosa, “Un mundo sin novelas"; Jorge Luis Borges, "Los libros"

1.7 Identificación y análisis de los recursos innovadores en algunos de los siguientes textos poéticos frente a la métrica tradicional (poemínimos, caligrama, haikú, poesía en prosa), Amado Nervo, Plenitud; Pablo Neruda ,"Las palabras", Veinte poemas de amor y una canción desesperada; José Juan Tablada Haikús, Li Po; Octavio Paz, Salamandra; Efraín Huerta, Poemínimos; José Gorostiza, Canciones para cantar en las barcas; Carlos Pellicer, Hora de junio; Xavier Villaurrutia, Nocturnos, Nostalgia de la muerte; Vicente Huidobro,

1.8 Altazor; César Vallejo, Trilce; Manuel Maples Arce, Andamios interiores, Urbe; Jorge Luis Borges, Fervor de Buenos Aires

1.9 Selección y lectura de textos narrativos de diferentes épocas relacionados con las innovaciones de la narrativa (juegos temporales y espaciales, tipo y punto de vista del narrador, monólogo interior). Felisberto Hernández "El balcón”; Alejo Carpentier, "Viaje a la semilla", Concierto barroco; Juan Rulfo, "Luvina", Pedro Páramo; Julio Cortázar, Historias de cronopios y famas; Jorge Luis Borges, “El jardín de los senderos que se bifurcan”, El Aleph; Manuel Maples Arce, La señorita etcétera; Jorge Ibargüengoitia, Las muertas; Augusto Monterroso, La oveja negra y otros relatos; Dina Grijalva Monteverde, Eros y Afrodita en la minificción

1.10 Selección y lectura de textos dramáticos de diferentes épocas relacionadas con las innovaciones del teatro experimental: Rodolfo Usigli, El gesticulador; Salvador Novo, 
La guerra de las gordas; Celestino Gorostiza, El color de nuestra piel; Samuel Eichelbaum, Un guapo de los novecientos; Xavier Villaurrutia, Invitación a la muerte; Emilio Carballido, Rosa de dos aromas; Elena Garro, La señora en su balcón; Luisa Josefina Hernández, El galán de ultramar, La amante; Vicente Leñero, La mudanza; Julio Castillo, De película; Alejandro Jodorowski, El juego que todos jugamos; Carlos Fuentes, Todos los gatos son pardos, Xavier Villaurrutia, Parece mentira; Osvaldo Dragún, Historia del hombre que se convirtió en perro; Jorge Díaz, Mata a tu prójimo como a ti mismo; Sergio Magaña, El pequeño caso de Jorge Lívido

1.11 Creación de un texto poético innovador (poemínimos, caligrama, haikú, poesía en prosa) o un texto narrativo(minificción)

\section{Contenidos actitudinales}

1.12 Valoración de los recursos innovadores estéticos, éticos e ideológicos de la poesía, la narrativa y el teatro

1.13 Apreciación del compromiso del escritor ante la problemática de su entorno

1.14 Estimación de la ruptura de valores establecidos para crear una propuesta literaria innovadora

1.15 Valoración de la literatura como una expresión artística en constante transformación

\section{Unidad2.Laidentidadnacionalylaotredad}

Objetivos específicos

El alumno:

- Reconocerá la literatura como vehículo de identidad nacional y cultural, a partir de la lectura de diferentes textos para concientizar los rasgos que lo definen frente al otro.

- Comprenderá los elementos de identidad mediante el análisis de la cosmogonía, la visión del mundo, el lenguaje, la idiosincrasia y las tradiciones en los textos literarios para relacionarlos con su ideología y su contexto

- Analizará la estructura y los elementos que conforman el ensayo, a partir de una lectura modelo para que identifique un texto de carácter argumentativo.

- Reflexionará de manera oral o escrita el tema de la otredad para manifestar su opinión con respecto a esta problemática.

\section{Contenidos conceptuales}

2.1 Concepto de identidad y los elementos que la conforman

2.2 Lo indígena y la negritud en la poesía y la prosa:

a) lenguaje: neologismos, regionalismos, indigenismos, negrismos

b) figuras literarias: comparación, metáfora, imagen, difrasismo, paralelismo, aliteración

c) ritmo y musicalidad

d) narrador y personajes

e) espacio y tiempo

2.3 Elementos del ensayo 


\section{Contenidos procedimentales}

2.4 Identificación y reflexión del concepto de identidad y de algunos aspectos que lo conforman (lenguaje, tradición, visión del mundo) en los siguientes textos: Roger Bartra, La jaula de la melancolía. Identidad y metamorfosis del mexicano; Octavio Paz, El laberinto de la soledad; Samuel Ramos, El perfil del mexicano; Guillermo Bonfil, México profundo, "El problema de la cultura nacional" y "La forja de una nación"

2.5 Selección y lectura de narrativa (mito, leyenda, crónica, novela, cuento), poesía y teatro que aborden los temas del indigenismo y la negritud. Miguel León Portilla, Visión de los vencidos; Antonio de Valdés, Ollantay; Popol Vuh; mitos, leyendas y poesía prehispánicos; Hernán Cortés, Cartas de relación; Bernal Díaz del Castillo Historia verdadera de la conquista de la Nueva España; Fray Toribio de Benavente "Motolinía", Historia de los indios de la Nueva España; Bernardo de Balbuena, Grandeza mexicana; Flores de baria poesía; Alonso de Ercilla, La Araucana; "E1 Inca" Garcilaso de la Vega, Comentarios reales; Sor Juana Inés de la Cruz, sonetos y villancicos; Francisco Xavier Clavijero, "El carácter de los mexicanos"; Rafael Landívar, Rusticatio mexicana; Ricardo Palma, Leyendas peruanas; Ciro Alegría, El mundo es ancho y ajeno; José María Arguedas, Los ríos profundos; Luis Palés Matos, "Danzarina africana"; Nicolás Guillén, Sóngorocosongo; Jorge Icaza, Huasipungo; Rosario Castellanos, "El tejoncito maya", Balún Canán; José Emilio Pacheco, "Ley de extranjería"; Ana Lydia Vega, En cancara nublado y otros cuentos de naufragio; Lydia Cabrera, Cuentos negros de Cuba

2.6 Análisis e interpretación de los aspectos culturales del mundo indígena y de la negritud en los textos seleccionados

2.7 Identificación y análisis de las figuras literarias y ritmo, musicalidad, lenguaje, narrador, personajes, espacio y tiempo

2.8 Redacción de una crónica que aborde el problema de la otredad Análisis e interpretación de la estructura del ensayo en algunos textos representativos: Gabriel Zaid, "La carretilla alfonsina"; Octavio Paz, "Máscaras mexicanas", "Todos santos, día de muertos"; Alfonso González, "Carlos Montemayor y la literatura indígena. Cara íntima de México"

\section{Contenidos actitudinales}

2.9 Reconocimiento de los elementos que conforman la identidad

2.10 Valoración del mundo indígena y la negritud

2.11 Respeto a la diversidad cultural de los países latinoamericanos

\section{Unidad3.Elhombreylanaturaleza}

Objetivos específicos

El alumno:

- Reconocerá y comprenderá la importancia de los elementos de la naturaleza utilizados por los autores para identificar la configuración del entorno poético o del espacio a partir del análisis de diferentes textos literarios.

- Reflexionará e interpretará la influencia de la naturaleza en la vida del hombre por 
medio de la lectura y análisis de los textos literarios con el fin de percibirla como un espacio mágico, agreste o dominado por el ser humano.

- Creará un cuento, a partir de su experiencia lectora, para abordar el tema de la naturaleza y su influencia en la conducta humana.

- Identificará los diferentes tipos de argumentos a partir del análisis de obras representativas para comprender el discurso argumentativo.

\section{Contenidos conceptuales}

3.1 Tópicos de la naturaleza en los textos literarios

3.2 Figuras literarias asociadas con el entorno natural: comparación, metáfora, antítesis, oxímoron, sinécdoque, hipérbole, prosopopeya, epíteto, aliteración, onomatopeya

3.3 La descripción de la naturaleza y su vinculación con el ser humano, como espacio mágico, agreste o dominado por el individuo

3.4 El cuento

3.5 Tipos de argumentos: de autoridad, personal, sentido común, analógico, entre otros 


\section{Contenidos procedimentales}

3.6 Selección y lectura de textos poéticos relacionados con la naturaleza o el paisaje americano: José Alcina Franch, Mitos y literatura azteca; Mitos y literatura maya; Flores de baria poesía; Carlos Sigüenza y Góngora “Glorias de Querétaro"; Andrés Bello, "La agricultura de la zona tórrida"; José Mármol "La noche oscura"; José María Heredia, "Chapultepec", "Niágara"; Guillermo Prieto, Musa callejera; José Martí, Versos sencillos; Rubén Darío, Azul; Leopoldo Lugones, Los crepúsculos del jardín; Ramón López Velarde, "Suave patria"; José Juan Tablada, Al sol bajo la luna; Vicente Huidobro, "La gruta del silencio", "La noche"; Alfonsina Storni, "Noche divina", "Frente al mar"; "Mar", Xavier Villaurrutia, "Nocturno rosa"; Octavio Paz, Obra poética; José Lezama Lima, Fragmentos desuimán

3.7 Análisis de los textos tomando en cuenta las figuras literarias relacionadas con los elementos de la naturaleza

3.8 Reflexión e interpretación, en los textos seleccionados, de los elementos de la naturaleza que conforman el entorno poético

3.9 Selección y lectura de textos narrativos relacionados con la naturaleza o el paisaje americano: José Alcina Franch, Mitos y literatura azteca; Mitos y literatura maya; Anales de los Cakchiqueles; Alvar Núñez Cabeza de Vaca, Naufragios y Comentarios; Pedro Mártir de Anglería, Libros de las décadas del Nuevo Mundo; Carlos de Sigüenza y Góngora, Los infortunios de Alonso Ramírez; Francisco Javier Clavijero ,Historia antigua de México; Ignacio Manuel Altamirano, Clemencia, El Zarco; Rafael Delgado, Angelina; Horacio Quiroga, Cuentos de la selva; José Eustasio Rivera, La vorágine; Leopoldo Lugones, Cuentos fatales; Ciro Alegría, Los perros hambrientos; José María Arguedas, Cuentos; Miguel Ángel Asturias, Hombres de maíz; Alejo Carpentier, La consagración de la primavera; Rosario Castellanos, Balún Canán; Rómulo Gallegos, Canaima; Juan Carlos Onetti, El astillero; José Revueltas, Los muros de agua; Juan Rulfo, El llano en llamas; Carlos Flaminio Rivera, El árbol imaginado

3.10 Reflexión e interpretación, en los textos seleccionados, de los elementos de la naturaleza como condicionantes de la conducta humana

3.11 Análisis e interpretación del papel de la naturaleza como un espacio mágico, agreste o dominado por el ser humano

3.12 Creación de un cuento a partir de su experiencia lectora abordando el tema de la naturaleza y su influencia en la conducta humana.

3.13 Distinción de los diferentes tipos de argumentos en obras representativas Contenidos actitudinales

3.14 Apreciación de la importancia de la naturaleza en la conformación de la literatura mexicana e iberoamericana

3.15 Reconocimiento de la naturaleza como determinante de la conducta humana

3.16 Valoración de la naturaleza como patrimonio del ser humano 
Unidad4.Laciudad literaria

Objetivos específicos:

El alumno:

- Comprenderá, mediante la lectura de textos literarios, la ciudad como ficción que refleja una realidad social, política, histórica, económica y moral, para tomar conciencia sobre el entorno urbano en el que se desarrolla la obra.

- Analizará el espacio literario y sus diferentes ambientes como generadores de conceptos, imágenes, historias, formas de vida, registros lingüísticos, personajes y comportamientos mediante la lectura de textos literarios para reflexionar y emitir opiniones sobre el panorama pesimista y optimista del contexto urbano.

- Redactará un texto argumentativo a partir del tema de la ciudad como pretexto para reflexionar sobre las problemáticas urbanas.

\section{Contenidos conceptuales}

4.1 El espacio urbano y su significación en la literatura: la verosimilitud del espacio físico 4.2 La construcción del espacio: físico, histórico, simbólico, psicológico, imaginario

4.3 La descripción del espacio: lo público y lo privado

4.4 El espacio y su vinculación con el personaje

$4.5 \mathrm{El}$ texto argumentativo

\section{Contenidos procedimentales}

4.6 Selección y lectura de alguna de las obras narrativas propuestas: José Joaquín Fernández de Lizardi, El Periquillo Sarniento; Emilio Rabasa, La gran ciencia, El cuarto poder; José Tomás de Cuellar, Baile y cochino; Luis González Obregón, Las calles de México y vetusteces; Artemio del Valle Arispe: Historia, tradiciones y leyendas de calles de México; Ángel de Campo, La Rumba; Artemio del Valle Arispe, La güera Rodríguez; Federico Gamboa, Santa; Enrique González Martínez, Los senderos ocultos; Manuel Gutiérrez Nájera, Cuentos de color de humo; Efrén Rebolledo, Salamandra; Alfonso Reyes, Visión de Anáhuac; Agustín Yáñez, Ojerosa y pintada; Marco Deveni, Rosaura a las diez; José Emilio Pacheco, Las batallas en el desierto; Ernesto Sábato, El túnel; Mario Vargas Llosa, La ciudad y los perros; Carlos Fuentes, Cantar de ciegos; Gustavo Sainz, Gazapo; José Agustín, De Perfil; Luis González Obregón, Las calles de México; Roberto Arlt, Los lanzallamas. Roberto Bolaño, Los detectives salvajes; María Luisa Puga, Pánico o peligro; Eusebio Ruvalcaba, Un hilito de sangre; Ricardo Piglia, La ciudad ausente; Antonio Malpica Mauri, No nos extrañará el sistema; María Fernanda Maquieira, Rompecabezas

4.7 Selección y lectura de alguna obra poética: Guillermo Prieto: romances y corridos; Ramón López Velarde: "Suave Patria”; Efraín Huerta: "Los hombres del Alba"; Jorge Luis Borges, 
Fervor de Buenos Aires; Oliverio Girondo, Veinte poemas para ser leídos en el tranvía; Octavio Paz, "De vuelta", "Por la calle de Galeana", "Hablo de la ciudad", "Nocturno de San Ildefonso"; Enrique Lihn, El Paseo Ahumada

4.8 Selección y lectura de alguna de las obras dramáticas: Miguel León Portilla, La visión de los vencidos; Fernando Alvarado Tezozómoc, Crónica mexicáyotl; Hernán Cortés, la segunda Carta de relación; Bernal Díaz del Castillo, Historia general de la conquista de la Nueva España; Francisco Cervantes de Salazar, Diálogos; Bernardo de Balbuena, Grandeza mexicana; Salvador Novo, La nueva grandeza mexicana; Elena Poniatowska, La noche de Tlaltelolco, Todo empezó el domingo, Las voces del temblor; Fabrizio Mejía Madrid, "Mazaric drive”, Pedro Uribe, Amor por la ciudad de México; Rodolfo Usigli, Medio tono; Alejandro Licona, Cuentas por cobrar; Antonio Argudín, Sueldo según capacidades; Emilio Carballido, D.F. 52 obras en unacto

4.9 Identificación y análisis de elementos literarios que conforman el espacio urbano en los textos leídos

4.10 Identificación de imágenes (subjetivas-objetivas y simbólicas) narrativasdescriptivas, poéticas, teatrales del espacio representado

4.11 Análisis e interpretación del espacio urbano en los textos leídos para vincularlos con el entorno social del alumno

4.12 Redacción de un texto argumentativo en torno a una problemática urbana

\section{Contenidos actitudinales}

4.13 Valoración de las distintas formas expresivas y de la pluralidad de miradas que la literaturaofrece y su relación con el contexto

4.14 Apreciación de la ciudad para promover el respeto, la conservación o la modificación de los espacios urbanos en función de la realidad social

\section{Unidad5.Elcompromisosocialyladenuncia}

Objetivos específicos

El alumno:

- Analizará las obras literarias que hacen referencia a la intolerancia social y a los sistemas opresores, a través de la lectura de textos representativos, para perfilar las como una denuncia de la desigualdad social, del ejercicio de la violencia y de las dictaduras latinoamericanas.

- Reflexionará e interpretará las características de esta literatura por medio de la lectura de textos y su contextualización histórico-política para identificar cómo surge la figura del sátrapa y cómo se manifiestan la denuncia y el compromiso social.

- Escribirá un ensayo literario por medio del análisis, la reflexión y la interpretación de la obra para fijar una postura, sólidamente argumentada, acerca de un problema social. 


\section{Contenidos conceptuales}

5.1 Características de la poesía de compromiso social:

a) figuras literarias: comparación, ironía, simbolismo, analogías, descripciones, metáfora, imagen visual, auditiva, entre otras

b) verso, rima, ritmo

5.2 Narrativa y teatro de compromiso social:

a) estructura

b) narrador y narratario en la novela y el cuento

c) construcción del sátrapa y de otros personajes

d) espacio y tiempo

e) lenguaje: regionalismos, indigenismos, entre otros

5.3 Influencia del contexto histórico-político en la configuración de la obra 5.4 El ensayo literario

\section{Contenidos procedimentales}

5.5 Selección y lectura de poemas que aborden los temas de compromiso social: Álvaro Yunque, Versos de la calle; Juan Gelman, En el hoy y mañana y ayer: antología personal; Jorge Boccanera, Monólogo del necio; Juan Gustavo Cobo Borda, Salón de té; Nicolás Guillén, Poesía-son, voz de dos gargantas, antología; Jorge Teillier, "Nostalgias del farwest"; Pablo Neruda, Canto general; Gonzalo Rojas, Antología poética; Jorge Carrera Andrade, Registro del mundo: Antología poética 1922-1939; Jorge Enrique Adoum, Antología poética: 1949-1998; Roque Dalton, Taberna y otros lugares; Luis Cardoza y Aragón, Material de lectura; Rubén Darío, Obras completas I: Poesía; Pablo Antonio Cuadra, El jaguar y la luna; César Vallejo, Poemas humanos; Antonio Cisneros, Propios como ajenos: antología personal (poesía 1961 2005); Mario Benedetti, Inventario; Andrés Eloy Blanco, Poesía

5.6 Comprensión de las figuras literarias, tipo de verso, ritmo, rima

5.7 Análisis e interpretación de las constantes temáticas para identificar los problemas que cada autor denuncia

5.8 Selección y lectura de textos narrativos y dramáticos que aborden los temas: intolerancia, sistemas opresores y compromiso social (militarización, violación de derechos humanos, resistencia, solidaridad, desplazamiento de grupos humanos), considerando la particular historia de Hispanoamérica. Esteban Echeverría, "El matadero"; Cirilo Villaverde, Cecilia Valdés o la Loma del Ángel; María Luisa Bombal, La amortajada; Julio Cortázar, Los premios; Mariano Azuela, Los de abajo; Martín Luis Guzmán, La sombra del caudillo; Juan Rulfo, Pedro Páramo; Luisa Valenzuela, Cola de lagartija; Roberto Bolaño, Estrella distante; Rafael Bernal, El Complot Mongol, José Hernández, Martín Fierro; Mario Vargas Llosa, Laciudad y los perros; Ignacio Rodríguez Galván, Muñoz, visitador de México; Mario Benedetti, Pedro y el capitán; Elena Garro, La muerte de Felipe Ángeles; Rodolfo Usigli, El niño y la niebla; Felipe Santander, Elextensionista

5.9 Análisis del lenguaje y de los elementos constitutivos de la obra: estructura, espacio, tiempo, tipo de narrador, personajes (el gaucho, los negros, los indios, el caudillo, el dictador, el tirano, el jefe supremo, el restaurador, el regenerador, el generalísimo) 
5.10 Revisión de conceptos para reconocer sus implicaciones: dictadura militar, populismo, gobierno autocrático, despotismo, totalitarismo, absolutismo, entre otros

5.11 Análisis e interpretación de las condicionantes sociales, económicas y políticas que propician los regímenes totalitarios y el compromiso social en los textos leídos

5.12 Escritura de un ensayo literario, con argumentos sólidos, en el que se plasme la postura del estudiante sobre algunos de los problemas analizados

\section{Contenidos actitudinales}

5.13 Reconocimiento del compromiso social como uno de los grandes temas de la literatura mexicana e iberoamericana

5.14 Valoración de los aspectos denunciados a través de la literatura

5.15 Actitud crítica ante las denuncias contra la desigualdad social, el ejercicio de la violencia y de los sistemas opresores

\section{Unidad6.Laexpresiónliterariafemenina Objetivos específicos}

El alumno:

- Reflexionará sobre los elementos que constituyen la expresión literaria femenina y los Estudios de Género, a partir de la lectura de distintos textos y de su análisis, para promover la equidad.

- Analizará e interpretará, mediante la lectura de textos, los temas, recursos y estrategias propios de la literatura femenina para reconocer el mundo desde la perspectiva de la mujer.

- Escribirá un ensayo académico por medio del análisis, la reflexión y la interpretación de la obra literaria para demostrar el dominio de la argumentación y del uso del aparato crítico.

\section{Contenidos conceptuales}

6.1 Poesía escrita por mujeres:

a) métrica y figuras literarias

b) temas: amor, desamor y erotismo, cuerpo, maternidad, soledad, masculinidad, equidad, violencia de género, entre otros

6.2 Narrativa y teatro escritos por mujeres:

a) la perspectiva del narrador en la novela y el cuento

b) la construcción del personaje femenino

c) los espacios y los ambientes 
d) temas: amor, desamor y erotismo, masculinidad, política y sociedad, poder, entre otros

6.3 El ensayo académico

\section{Contenidos procedimentales}

6.4 Selección y lectura de diferentes textos de poetas latinoamericanas que aborden el problema de género. Sor Juana Inés de la Cruz, "Hombres necios"; Rosario Castellanos, Poesía no eres tú; Gioconda Belli, El ojo de la mujer; Alaíde Foppa, Elogio de mi cuerpo; Alfonsina Storni, El dulce daño; Delmira Agustini, El rosario de Eros; Claribel Alegría, Anillo de silencio; Eunice Odio, Los elementos terrestres; Ana Istarú, La estación de fiebre

6.5 Identificaciónyanálisisdeloselementosformalesdelapoesíafemenina(metro,rima,ritmo)

6.6 Reflexión sobre recursos y estrategias como ironía, parodia, ira, léxico cotidiano, intertextualidad, entre otros

6.7 Interpretación del contenido de las obras seleccionadas a partir de los estudios de género en la literatura.

6.8 Selección y lectura de diferentes textos de narradoras y dramaturgas latinoamericanas que aborden el problema de género. Inés Arredondo, "La sunamita"; Elena Garro, Los recuerdos del porvenir; Julia Álvarez, En el tiempo de las mariposas; Ángeles Mastreta, Arráncame la vida; Silvia Molina, La mañana debe seguir gris; María Luisa Bombal, La última niebla; Elena Poniatowska, Querido Diego, te abraza Quiela; Rosario Ferré, La casa de la laguna; Isabel Allende ,La casa de los espíritus; Rosario Castellanos, "El viudo Román"; Griselda Gambaro, Ganarse la muerte; Isidora Aguirre, Diálogo de fin de siglo; Fanny Buitrago, Al final del Ave María; Luisa Josefina Hernández, El orden de los factores; Ana Istarú, Madre nuestra que estás en la tierra; Sabina Berman, Entre Pancho Villa y una mujer desnuda; María Luisa Ocampo, La casa en ruinas

6.9 Identificación y análisis de los elementos formales de la narrativa femenina (estructura, narrador, personajes, tiempo, espacio)

6.10 Reflexión sobre recursos y estrategias tales como la ira, el humor, el lenguaje, la intertextualidad, el testimonio, entre otros

6.11 Interpretación del contenido de las obras seleccionadas a partir de los estudios de género en la literatura

6.12 Redacción de un ensayo académico cuyo asunto gire en torno a un tema tratado por la literatura femenina, utilizando de manera adecuada la argumentación y el aparato crítico

\section{Contenidos actitudinales}

6.13 Reconocimiento de los elementos que conforman el mundo femenino en la literatura

6.14 Apreciación de la trascendencia de la literatura escrita por mujeres para promover un mundo más igualitario

6.15 Valoración de la importancia de la equidad de género en las sociedades actuales 


\section{Sugerencias de trabajo}

El programa ofrece una amplia gama de obras de las cuales el profesor podrá elegir aquellas que sean apropiadas a las características de sus grupos, las horas planeadas de clases y su experiencia docente. En modo alguno los textos son exhaustivos ni la propuesta es limitada, por el contrario, subyace la libertad del profesor para optar por aquellas que considere idóneas a los temas abordados en cada unidad.

Es conveniente elaborar secuencias didácticas para la planeación del curso pues se convierten en una herramienta inapreciable que permite una visión panorámica y organizada de los objetivos, contenidos, seguimiento de actividades, materiales didácticos, uso de TIC y evidencias de trabajo que faciliten evaluar el proceso de enseñanza-aprendizaje a lo largo de cada unidad. De igual manera, en los contenidos procedimentales es fundamental promover el trabajo colaborativo, las revisiones y las evaluaciones entre pares y grupales, resaltando valores como la responsabilidad, el respeto, la solidaridad y la empatía.

Para desarrollar las habilidades correspondientes a la metodología de la investigación, se propone el uso de las TIC como herramientas, se sugiere tomar en cuenta las fases del proceso de investigación con el fin de elaborar los textos argumentativos: a) Delimitación del tema, b) Búsqueda y selección de la información y c) Elaboración de fichas de trabajo y registro de fuentes en formato APA.

Durante el proceso de lectura es importante definir e identificar los elementos del análisis literario, con la finalidad de abordar los grandes temas propuestos y los conflictos planteados en la interpretación del texto. Se recomienda: a) Búsqueda del contexto del autor y de la obra en libros y/o medios electrónicos (características de la escuela, corriente, generación, movimiento o época literaria a la que pertenece), b) Durante la lectura: revisión del léxico (se puede revisar en cualquier etapa del proceso, de acuerdo al texto seleccionado); comprensión y recapitulación del contenido, confirmación o modificación de la hipótesis y evaluación del contenido, y c) Después de la lectura: confirmación o negación de hipótesis; generación de inferencias lógicas y verificación de la comprensión.

Para el proceso de lectura, y dando continuidad a las etapas propuestas en Lengua Española y Literatura Universal, se recomienda:

Antes de la lectura

a. Señalamiento de la finalidad lectora

b. Activación de conocimientos previos

c. Aproximación previa al vocabulario del texto

d. Reconocimiento de la estructura del texto

e. Vaticinio del contenido a partir del título 
Durante de la lectura
a. Realización de inferencias
b. Recapitulación periódica del contenido
c. Planteamiento de hipótesis
d. Aclaración de dudas de léxico y expresiones
e. Evaluación del contenido y la forma del texto con relación al propio conocimiento

Después de la lectura
a. Generación de inferencias, conclusiones, implicaciones; evocaciones, asociaciones, relación de ideas, hechos y estructura
b. Deducción del tema e intencionalidad
c. Asociación del mensaje del texto con la realidad
d. Síntesis del conocimiento
e. Generalización/aplicación del conocimiento
f. Extrapolación del contenido a otros soportes de comunicación

En el programa se trabajan dos formas de escritura: la académica, que inicia con el análisis y la construcción de textos argumentativos para concluir con la redacción de ensayo literario y académico; la creativa, que sugiere la escritura de textos literarios poéticos y narrativos. Es recomendable trabajar ambas formas de escritura pues apoyan el desarrollo delas habilidades lingüísticas, la toma de conciencia del entorno, la transversalidad y la práctica de valores. Se propone trabajar el proceso de escritura:

a. Contextualización. Interpretar las obras para producir un texto coherente en función de la situación comunicativa, identificar el enunciatario, la postura del enunciador y el hilo conductor que dará cohesión y unidad.

b. Elaboración. Seleccionar la información pertinente y dar equilibrio entre ésta y el aporte de nuevas informaciones. Usar el registro, formal o informal, según el texto escrito elegido.

c. Planificación. Considerar la estructura del texto, siguiendo un orden y una jerarquía.

d. Textualización. Emplear marcas lingüísticas como signos de puntuación, párrafos, conectores textuales; revisar oraciones enunciativas, uso de la persona gramatical, tiempos y modos verbales, cohesión y coherencia.

e. Relectura. Revisar adecuación, coherencia, cohesión y ortografía; reescribir el texto a partir de un borrador.

Otras actividades formativas que favorecen el proceso de escritura creativa pueden ser:

a. Recopilación de mitos y leyendas propios de la colonia o del barrio donde vive el estudiante.

b. Creación de cadáveres exquisitos, poemas dadaístas, entre otros.

c. Imitación de modelos clásicos. 
Para promover el aprendizaje significativo, se sugieren las siguientes estrategias de enseñanza: activación de conocimientos previos, lluvia de ideas, pistas tipográficas y discursivas, organizadores anticipados, discusión dirigida, preguntas intercaladas, diseño de líneas del tiempo, cuadros sinópticos o comparativos, mapas conceptuales o mentales, resúmenes, uso de diccionarios especializados, elaboración de cuestionarios y fichas de trabajo.

Los recursos digitales, como herramienta de enseñanza, constituyen uno de los ejes transversales del bachillerato pues apoyan el aprendizaje. Se sugiere el uso de películas, documentales y videos, wikis, presentaciones electrónicas, podcast, booktube (comunidad de jóvenes lectores) o aplicaciones como: ExamTime, Socrative Teacher y Student, Inspiration Maps, Padlet, Mohiomap, Text2MindMap, Keynote, iMovie, Prezi, Dropbox, Drive, Evernote, Comic Book, Creator, Book Creator, Pixton Comics, entre otros.

\section{Sugerencias de evaluación del aprendizaje}

En la elaboración de secuencias didácticas se debe considerar los siguientes tipos de evaluaciones: diagnóstica, continua, sumativa. El proceso de evaluación debe ser constante, a lo largo de la formación del alumno, para identificar problemas de aprendizaje, comprender sus causas y reflexionar sobre el avance del conocimiento y el desarrollo de las habilidades.

Las evidencias de trabajo y los productos a evaluar pueden ser pruebas escritas, mapas mentales, cuestionarios, resúmenes, síntesis, investigaciones, exposiciones, debates, lectura en voz alta (en atril), escritos académicos y creativos, considerando los borradores de los mismos. Para evaluar también se pueden considerar los siguientes instrumentos: listas de cotejo, rúbricas, portafolio de evidencias, pues favorecen no sólo la evaluación objetiva, sino también la autoevaluación, coevaluación y heteroevaluación.

\section{Fuentes básicas}

Ballester, J. (2015). La formación lectora y literaria. Barcelona: Graó

Bordons, G. y Díaz-Plaja, A. (coords.). (2006). Enseñar literatura en secundaria. La formación de lectores críticos, motivados y cultos. Barcelona: Graó.

Camps, A. (2008). Secuencias didácticas para aprender a escribir.

Barcelona: Graó. Cassany, D. (2012). En línea. Leer y escribir en la red.

Barcelona: Anagrama.

García Barrientos, J. L. (2007). Análisis de la dramaturgia. Nueve obras y un método. Madrid: Fundamentos.

Jover,G. (coord.) (2009). Constelaciones literarias. Sentirse raro. Miradas sobre la adolescencia. Málaga: Consejería de educación de la Junta de Andalucía. Recuperado de: http://www.juntadeandalucia.es/educacion/webportal/abacoportlet/content/015af8 $\underline{3 c-3362-4 f 74-929 c-a f 321 e 6 e 6 f 36}$ 
Larrosa, J. (2000). La experiencia de la lectura. Estudios sobre la literatura y formación. México: F.C.E.

Lomas, C. (2014). La educación lingüística, entre el deseo y la realidad. Competencias comunicativas y enseñanza del lenguaje. México: Flacso/Octaedro.

----------- (comp.). (2015). Fundamentos para una enseñanza comunicativa del

lenguaje.

Barcelona: Graó

Masó, J. (ed.) (2008). Escrituras de la sexualidad. Barcelona: Icaria

Moreno, V. (2004). El deseo de escribir. Propuesta para despertar y mantener el gusto por la escritura. México: Ediciones Alejandría/Pamiela.

---------- (2011). Cómo hacer lectores competentes. Guía práctica: reflexiones

ypropuestas.

México: Ediciones Alejandría/Pamiela.

Petit, M. (2009). El arte de la lectura en tiempos de crisis. México:

Océano. Pimentel, L. A. (1998). El relato en perspectiva. México:

UNAM/SigloXXI.

------------ (2001). El espacio en la ficción. México: UNAM/Siglo

XXI. Rosenblatt, L. M. (2002). La Literatura como exploración.

México: F.C.E. Solé, I. (2007). Estrategias de lectura. Barcelona:

Graó.

Spang, K. (1993). Géneros literarios. Madrid: Síntesis.

Madrid:Euns.

Strauss, B. (2006). Crítica teatral: las nuevas fronteras: análisis de los acontecimientos estéticos y políticos involucrados en la acción teatral. Barcelona:Gedisa.

Tomás, N. T. (2004) Arte del verso. Madrid: Visor libros.

\section{Obras literarias sugeridas}

A continuación, se proponen una serie de autores y lecturas, el criterio de selección obedece a la temática y a las constelaciones literarias que se trabajan en cada unidad. La relación no es restrictiva ni exhaustiva, por lo tanto, hay libertad de elegir las lecturas más apropiadas.

\section{Unidad 1}

Argudín, Antonio, Sueldo según capacidades.

Arlt, Roberto, Teatro completo.

Arredondo Inés, Obras completas.

Bioy Casares, Adolfo, Historias fantásticas, Historias de amor.

Borges, Jorge Luis, El libro de arena, El informe de

Brodie. Brull, Mariano, Obras Poesía y Prosa: 1916-

1955.

Buenaventura, Enrique, Aladino y la lámpara maravillosa, La autopsia.

Cabrujas, José Ignacio, El día que me

quieras.

Cáceres, Omar, Defensa del ídolo. 
Carballido, Emilio, Te juro Juana que tengo ganas.

Conrado, Nalé Roxlo, Judith y las rosas.

Cortázar Julio, Todos los fuegos el fuego, Octaedro, La otra orilla.

Díaz, Jorge, Mata a tu prójimo como a ti mismo, Acerca de la libertad, los elefantes y otras zoologías.

Dragún, Osvaldo, Historia del hombre que se convirtió en perro.

Gallardo, Salvador, Antología

inconclusa.

Garro, Elena, Un hogar sólido.

González; Rojo Enrique, Criaturas de la tinta alada.

González; Rojo Enrique, Romance de José Conde.

Hernández, Felisberto La casa inundada, Las

hortensias. Hernández, Luisa Josefina, Los huéspedes

reales.

Huidobro, Vicente Obra poética.

Licona, Alejandro, Cómo pasar matemáticas sin problemas, Cuentas por cobrar.

Liera, Oscar, El jinete de la Divina providencia.

Lomelí, Luis Felipe, Indio borrado, Ella sigue

de viaje.

López, Willebaldo, Cosas de muchachos.

Magaña, Esquivel Antonio, Teatro mexicano del siglo XX.

Maples, Arce Manuel, Las semillas del tiempo: obra poética,

"Prisma". Monterroso, Augusto, La palabra mágica.

Novo Salvador, Poesías escogidas.

Oliverio Girondo, Espantapájaros, Persuasión de los días, Interlunio.

Ortíz de Montellano Bernardo, Red, Sueños.

Paz Octavio, Libertad bajo palabra, Topoemas, Discos visuales.

Rebolledo, Efrén, Estela, Caro victrix.

Ruvalcaba, Eusebio, La visita.

Sabdiel, Yéred, La espantosa y marginal vida de Godzilla.

Sada, Daniel, Casi nunca, Antología presentida.

Salazar, Bondy Sebastián, No hay isla feliz.

Samperio, Guillermo, Antología personal.

Torri, Julio, De fusilamientos; Prosas dispersas, Ensayos y poemas.

Triana, José, La noche de los asesinos.

Usigli, Gorostiza, Villaurrutia, Novo, Vicente Leñero, Luis G. Basurto, Julio Castillo.

Carlos Solórzano; Héctor Mendoza, Jesús González Dávila.

Valenzuela, Teresa, Estela y la geografía política.

Vallejo, César, Escalas melografiadas, Fabla salvaje, Heraldos negros.

Villegas, Oscar, La Pira.

\section{Unidad 2}

Agustín Yánez, Al filo del agua.

Arguedas José María, Yawar fiesta.

Asturias, Miguel Ángel, Hombres de

maíz. 
Bañuelos, Juan "Instantáneas de una estela maya" Vivo, eso sucede: poesía reunida.

Cardenal, Ernesto, Canto nacional, Las ínsulas extrañas.

Cardoza y Aragón, Luis "Paisaje de

Coatlicue".

Cross, Elsa, Visible y no.

Dauajare, Félix, Definiciones; poemas.

Galeano Eduardo, Las venas abiertas de América Latina, Patas arriba La escuela del mundo al revés, Los hijos de los días.

Lugones Leopoldo, El Payador.

Martínez Tomas Eloy, Santa

Evita. Magaña Sergio,

"Moctezuma II".

Piglia, Ricardo, Respiración artificial, Plata quemada.

Revueltas, José, El luto human.

Rojas González, Francisco El Diosero y todos los cuentos.

Rodríguez Galván, Ignacio, "Profecía de Guatimoc”, “La visión de

Moctezuma”.

Traven, Bruno Canasta de cuentos mexicanos.

\section{Unidad 3}

Abreu Gómez, Emilio, Canek

Acuña, Manuel, Poemas.

Alegría, José Ciro,

Leyendas.

Amado, José Mar muerto, Los viejos marinos.

Asturias, Miguel Ángel Cuentos, Hombres de maíz, Mulata de tal.

Asunción, Silva José, Obra poética.

Bello, Andrés, Silvas.

Borges, Jorge Luis, Luna de enfrente, Historia de la noche.

Carpentier, Alejo, Cuentos.

Casal, Julián de, Poemas.

De la Vega, Garcilaso "El Inca”, La Florida.

Echeverría, Esteban, La cautiva.

Fernández de Oviedo, Gonzalo, Historia general y natural de las indias. Joseph de Acosta, Historial natural y moral de las Indias.

Gallegos, Rómulo Cuentos completos.

García, Márquez Gabriel, Cuentos, La hojarasca, El amor en los tiempos del cólera.

González, Martínez Enrique, El romero alucinado.

Gorostiza, José, Canciones para cantar en las barcas.

Guillén, Nicolás, Motivos del son, Sones para turistas y España.

Hernández, José, Martín Fierro.

Ibarbourou, Juana de Lenguas de diamante, "Como la primavera", "Raíz salvaje". Icaza, Jorge, Relatos, Cholos.

Landívar, Rafael, Rusticatio mexicana.

Lezama, Lima Cuentos.

Lezama, Lima José, Aventuras sigilosas, Dador. 
Neruda, Pablo, Crepusculario; Veinte poemas de amor y una canción desesperada.

Nervo, Amado, Los jardines interiores.

Onetti, Juan Carlos Tierra de

nadie. Othón, José María, Nuevas

poesías.

Owen, Gilberto, "El naufragio", "Espera octubre"; Perseo vencido.

Revueltas, José Dormir en tierra, El luto humano.

Rivera, José Eustasio, Tierra de promisión.

Roa Bárcenas, José María y Riva Palacio, Vicente, Tradiciones y Leyendas mexicanas.

Sierra, Justo, Cuentos románticos.

Torres, Bodet Jaime, Trébol de cuatro hojas.

Uslar, Pietri Arturo, La lluvia y otros cuentos, Treinta cuentos.

Vargas Llosa Mario La casa verde, Lituma en los Andes.

Von Humboldt, Alejandro, Vistas de las cordilleras y monumentos de los pueblos

indígenas de América.

\section{Unidad 4}

Agustín, José, Círculo vicioso.

Campo, Ángel de Ocios y apuntes, Cosas vistas y

cartones. Cuellar, José Tomás de, Ensalada de Pollos, Los

fuereños. Fernández de Lizardi José Joaquín, Don Catrín

de la Fachenda. Hernández, Francisco, La isla de las

breves ausencias González, Obregón, Luis, México viejo.

Licona, Alejandro, Cómo pasar matemáticas sin problemas.

Morabito, Favio, La vida ordenada.

Pacheco, José Emilio, El viento distante.

Sainz, Gustavo, La princesa del Palacio de

Hierro. Usigli, Rodolfo, El gesticulador.

Monsiváis, Carlos. (1980) A ustedes les consta. Antología de la crónica en México.

Unidad 5

Aguilera, Malta, Demetrio, Canal zone.

Alegría, Ciro, Los perros hambrientos.

Ampuero, Roberto, Nuestros años

verdeolivo.

Arenas Reinaldo, Arturo, La estrella más brillante, Antes que anochezca.

Arévalo Martínez Rafael "Las fieras del

trópico".

Ascencio Segura Manuel, El sargento

Canuto.

Azuela, Mariano, Mala yerba.

Barba Jacob, Porfirio, Rosas negras.

Barquero, Efraín, "Los sacrificados" "Galopan las patrullas" "El

cazador".

Basurto, Luis G., El candidato de Dios.

Belli Carlos Germán, "A modo de un pintor primitivo culto", "mamá, papá”. Berenguer Amanda, "No quieres venir a llorar conmigo", El río y 
otros poemas. Blanco Fombona Roberto, "Democracia criolla.

Blest Gana Alberto, Martín Rivas.

Bombal María Luisa, “El árbol”.

Bosch, Juan, Camino real.

Cabello, Mercedes Carbonera, El conspirador.

Cadenas, Rafael, Antología, 1958-1983, Obra entera: poesía prosa, 19581995.

Cardenal, Ernesto, Antología.

Carpentier, Alejo "El acoso", El recurso del método.

Chamorro, Joaquín, Cuentos.

Conrado Nalé Roxlo Judith y las rosas.

Constantini, Humberto, Cuestiones con la vida: Antología poética. 
Cortázar Julio, "Segunda vez”.

Díaz Eterovic Ramón, La ciudad está triste, Los siete hijos de Simenon

Dragún Osvaldo, Tupac Amaru.

Electorat Mauricio, La burla del

tiempo. Estrada Antonio, Rescoldos.

Fernández de Lizardi José Joaquín, El Periquillo Sarniento El unipersonal de Agustín de Iturbide.

Fernández Retamar Roberto, Felices los normales: poesías escogidas, 1949-1999.

Ferré Rosario, "La bella durmiente”, Maldito amor.

Fonseca Rubem, Pasado Negro, Agosto.

Fuentes Carlos, La muerte de Artemio

Cruz. Gallegos Rómulo, El forastero.

García Márquez Gabriel, El otoño del Patriarca.

Garro Elena Y Matarazo no llamó.

Gerbasi Vicente, Los espacios cálidos y otros poemas, Antología poética, 1943-1968.

Giardinelli Mempo, Luna caliente.

González Otto Raúl, Los Hermosos animales, Huitziluantuxtli. Colibrí y Conejo.

González Prada Manuel, Horas de lucha.

González Tuñón Raúl, "De pronto entró la libertad”, "El poeta murió al

amanecer”. Hernández José, Martín Fierro, La vuelta de Martín Fierro.

Herrera Ernesto, El león ciego.

Hinostroza Rodolfo, Poesía completa, Consejero del lobo.

Ibargoyen Saúl, El poeta y yo, Juntaversos, Gran cambalache, La última bandera.

Ibargüengoitia Jorge, Maten al león.

Jamís, Fayad, Abrí la verja de hierro, Los puentes.

Lacunza José María, Netzula.

Laforucade Enrique, La fiesta del rey Akab.

Lara Zavala Hernán, Charras.

Lavín Cerda Hernán Tal vez un poco de eternidad, Divagaciones del pequeño filósofo.

Lazo Olegario, Cuentos militares.

Lihn Enrique, Al bello aparecer de este lucero, La pieza

oscura. López Willebaldo, Cosas de muchachos.

Mármol José, Amalia.

Mateos, Juan A., El cerro de las campanas. Memorias de un guerrillero.

Matto de Turner, Clorinda, Aves sin nido.

Miguel Ángel, El señor Presidente.

Montalvo, Juan, Las catilinarias.

Montemayor, Carlos, La guerra en el paraíso.

Nieto Cadena, Fernando "Coincidimos en confundir la historia", "Somos asunto de

muchísimas personas".

Olvera, Omar, Para la libertad.

Onetti, Juan Carlos Junta cadáveres.

Padura Fuente, Leonardo, Paisaje de Otoño.

Parra Nicanor, Sermones y prédicas del Cristo de Elqui, Hojas de Parra. 
Pasos, Joaquín, Canto de guerra de las cosas y otros poemas.

Payró, Roberto J., "Probidad".

Pedroso, Regino, Antología de la poesía cósmica de Regino Pedroso.

Piñera Virgilio, Electra Garrigó.

Portogalo José, Entre los poetas

míos.

Posse, Abel, Los perros del paraíso.

Prieto, Guillermo, Memorias de mis tiempos.

Ribeyro, Julio Ramón, “Los gallinazos sin

plumas". Riva Palacio Vicente, Calvario y

Tabor.

Roa Bastos, Augusto, Yo el supremo.

Rodó, José Enrique, Ariel.

Rojas Guardia, Armando, Del mismo amor ardiendo.

Rokha, Pablo de, Epopeya de las comidas y bebidas de Chile.

Sábato, Ernesto, Sobre héroes y tumbas, Abaddón, el

exterminador. Sarmiento Domingo Faustino, Facundo.

Sebastián, Salazar Bondy, No hay isla feliz.

Soriano, Osvaldo, Cuarteles de invierno.

Taboada, Terán Néstor, La tempestad y la sombra.

Urbaneja Achelphol, Luis Manuel, "El

ancestro".

Uslar Pietri, Arturo, Oficio de difuntos.

Vargas Llosa, Mario, Los cachorros, Conversación en La

Catedral. Vergara José María, “Consejos a mi potro”.

Vicente Leñero, Dramaturgia terminal.

Zalamea Jorge, El gran Burundum-Burundá ha muerto.

Zarco, Francisco "El Palacio Nacional".

Zepeda, Patterson Jorge, Los

corruptores.

\section{Unidad 6}

Aguirre, Isidora, Los que van quedando en el

camino.

Algarra, María Luisa, Casandra o La llave sin

puerta.

Amor, Guadalupe, Yo soy m icasa.

Arredondo, Inés, Obra scompletas.

Azcárate, Leonor, Las alas del poder.

Azcona Cranwell, Elizabeth, Imposibilidad del lenguaje o los nombres del amor.

Beltrán, Rosa, La corte de los ilusos.

Berman, Sabina, La mujer que buceó en el corazón del mundo.

Boullosa, Carmen, Los totoles, Todos los amores: antología de poesía amorosa.

Bracho, Coral, Huellas de luz.

Buitrago, Fanny, Señora de la Miel.

Burgos, Julia de, Poemas en veinte surcos. 
Caballero de Castillo Ledón, Amalia, Cuando las hojas

caen. Camarillo, María Enriqueta, Rincones

románticos.

Campos, Julieta, Muerte por agua.

Campobello, Nellie, Cartucho.

Castellanos, Rosario, Los convidados de agosto, El eterno femenino.

Cross, Elsa, Amor el más oscuro.

Cruz, Sor Juana Inés de la, Obras completas.

Dávila, Amparo, Cuentos reunidos.

Eltit, Diamela El padre mío.

Esquivel, Laura, Como agua para

chocolate.

García Bergua, Ana, La bomba de San

José.

Garro, Elena, La señora en su balcón.

Glantz, Margo, Síndrome de naufragios.

Gómez de Avellaneda, Gertrudis, Poesías líricas.

González de León, Ulalume,

Plagios. Gramcko, Ida, Sol y

soledades.

Grijalva, Dina, Las dos caras de la luna.

Guido, Beatriz Fin de fiesta.

Hernández, Luisa Josefina, La cólera secreta, Los frutos caídos.

Ibarbourou, Juana de, Las lenguas del diamante.

Jacobs, Bárbara, Las hojas muertas.

Krauze, Ethel, El secreto de la

infidelidad. Lair, Clara, Trópico

amargo.

Laoeza, Guadalupe, Niñas mal.

López Colomé, Pura, Poemas reunidos.

López Mills, Tedi, Un jardín, cinco noche (otros poemas).

Macías, Elva, Imperio móvil.

Méndez de Cuenca, Concha, Simplezas.

Mistral, Gabriela, Desolación.

Moscona, Myriam, El que nada.

Ocampo, Silvina, La promesa.

Orozco, Olga, La noche a la

deriva.

Pettersson, Aline, Colores y sobras. Tres novelas.

Peralta, Bertalicia, Atrincherado

amor.

Peri Rossi, Cristina, Cuentos

reunidos.

Pizarnik, Alejandra, Obra completa. 
Poniatowska, Elena, Hasta no verte Jesús

mío.

Puga, María Luisa, Los siete pecados

capitales.

Sada, Concepción, Como yo te soñaba.

Sefchovich, Sara, Demasiado amor.

Seligson, Esther, Toda la luz.

Serrana, Elisa, Chilena, casada, sin profesión.

Serrano, Marcela, Nosotras que nos queremos

tanto.

Storni, Alfonsina, La inquietud del rosal.

Urueta, Margarita, El hombre y la máscara, El señor perro.

Valenzuela, María Luisa, Cola de lagartija.

Varela, Blanca, Ese puerto existe.

Vicens, Josefina, El libro vacío.

Vilalta, Maruxa, El otro día, la muerte.

Volkow, Verónica, Litoral de tinta y otros poemas

Fuentes complementarias

Amate Blanco, J. J. (abril 1981). "La novela del dictador en Hispanoamérica" en Cuadernos Hispanoamericanos núm. 370. Recuperado de: http://www.cervantesvirtual.com/obra/la-novela-del-dictador-en-hispanoamerica/

Bellini, G. (2000). El tema de la dictadura en la narrativa del mundo hispánico siglo XX, Roma: Bulzoni Editore. Recuperado de: http://www.cervantesvirtual.com/obravisor/el-tema-de-la-dictadura-en-la-narrativa-del-mundo-hispnico---siglo-xxO/html/

Cardoza y Aragón, L. (1944). Apolo y Coatlicue. Ensayos mexicanos de espina y flor. México: La serpiente emplumada.

García,J. C. (1999). El dictador en la literatura hispanoamericana. Recuperado de: https://tspace.library.utoronto.ca/bitstream/1807/12912/1/NQ45793.pdf

Lagarde, M. (2005) Los cautiverios de las mujeres, madresposas, monjas, putas, presas y locas. México: UNAM

O’Gorman, E. (1995). La invención de América. México: F.C.E.

Ortega, J. (1988). Critica de la identidad. La pregunta por el Perú en su literatura. México: F.C.E.

Pons, M. C. "La novela negra argentina. Parodia y homenaje en dos novelas de Osvaldo Soriano" en Revista de la Universidad de México, octubre 1996, pp. 28-34.

Recuperado de: http://www.revistadelauniversidad.unam.mx/ojs_rum/files/journals/1/articles/1444 3/public/14443-19841-1-PB.pdf

Schneider, L. M. (2007). El estridentismo. La vanguardia literaria en México. México:

UNAM. Yurkievich, S. (coord.) (1986). Identidad cultural de Iberoamérica en su literatura. Madrid:

Alhambra.

\section{Perfil profesiográfico}

- Se debe cumplir con los requisitos que señala el Estatuto del Personal Académico de la UNAM (EPA) y el Sistema de Desarrollo de Personal Académico de la 


\section{ENP(SIDEPA).}

- Licenciado en: Lengua y literatura(s) hispánicas, Letras Hispánicas, Escritura creativa y literatura, Letras Clásicas.

- Maestro o Doctor en Letras: Latinoamericanas, Mexicanas, Españolas, Linguística, Humanidades: Literatura o Teoría Literaria.

- Docencia para la enseñanza Media Superior en Español (MADEMS).

- Maestro Normalista con especialidad en la enseñanza del español y con estudios de posgrado en: letras españolas, latinoamericanas, mexicanas y lingüística. 
Se recomienda contar con experiencia en docencia y demostrar las siguientes habilidades y actitudes necesarias para impartir la asignatura:

- Dominar y conocer de la disciplina.

- Planificar el proceso de enseñanza-aprendizaje, seleccionando y preparando los contenidos de la disciplina y las estrategias didácticas para abordarlos, así como los instrumentos de evaluación.

- Emplear estrategias didácticas adecuadas para el aprendizaje en grupo numerosos.

- Conocer las características psicológicas del adolescente.

- Establecer una comunicación clara con los estudiantes.

- Conocer la aplicación didáctica de las Tecnologías de la Información y la Comunicación (TIC).

- Seleccionar el material didáctico que propicie el hábito lector.

- Actuar de manera positiva para propiciar la reflexión en el aula.

- Estar dispuesto para el trabajo interdisciplinario, colaborativo, de investigación y de aprendizaje. 


\section{Plan de Estudios de la Escuela Nacional Preparatoria Sintético}

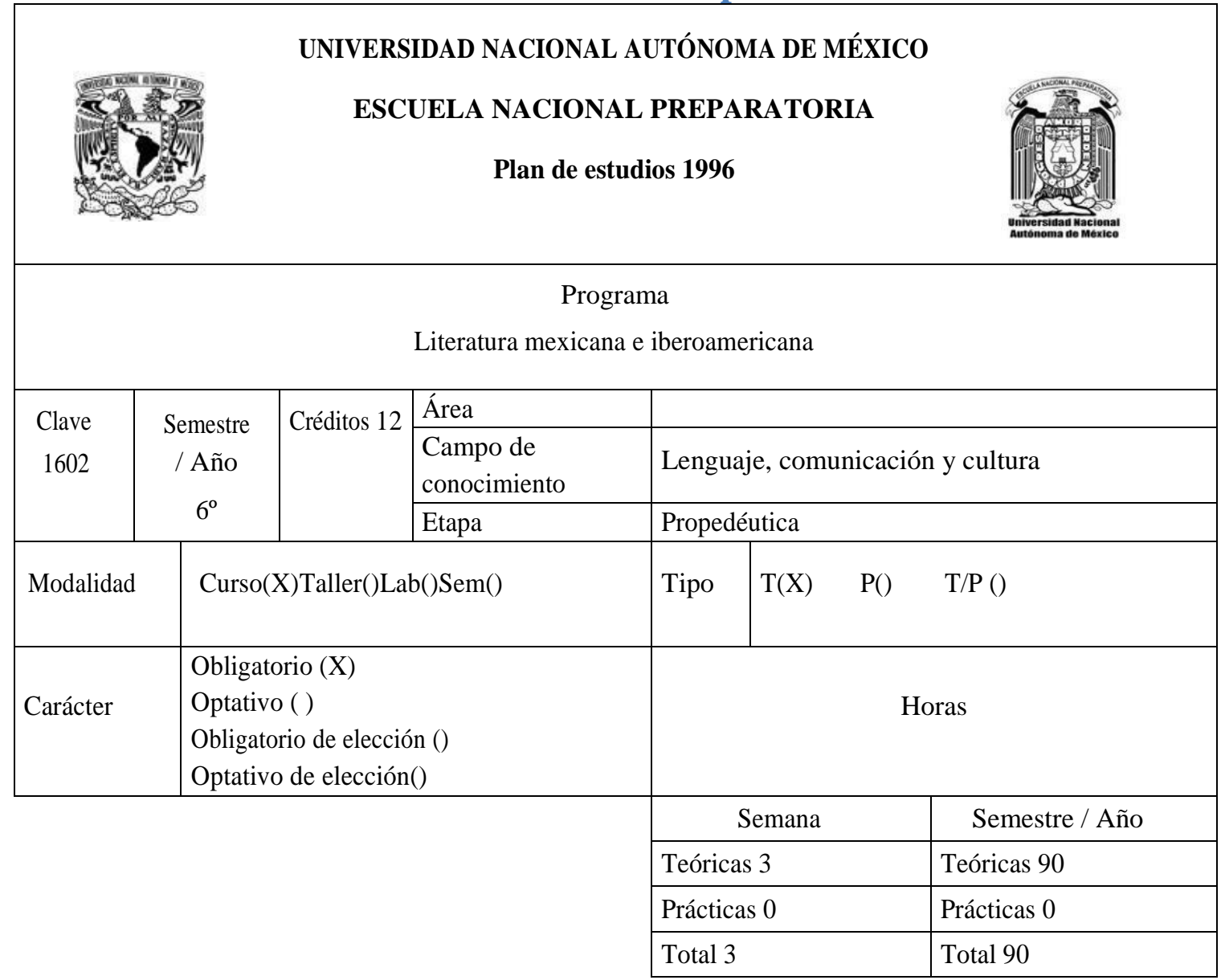

\begin{tabular}{|l|c|}
\hline \multicolumn{2}{|c|}{ Seriación } \\
\hline \multicolumn{2}{|c|}{ Ninguna ( ) } \\
\hline \multicolumn{2}{|c|}{ Obligatoria (X) } \\
\hline Asignatura antecedente & Literatura Universal \\
\hline Asignatura subsecuente & Indicativa ( ) \\
\hline \multicolumn{2}{|c|}{} \\
\hline Asignatura antecedente & \\
\hline Asignatura subsecuente & \\
\hline
\end{tabular}

Aprobado por el H. Consejo Técnico el 13 de abril de 2018 


\section{Presentación}

Objetivo general:

La asignatura de Literatura mexicana e iberoamericana tiene como objetivo general que el alumno lea, comprenda e interprete obras representativas latinoamericanas, a partir del análisis y la producción de textos que contribuyan al fortalecimiento de su identidad, a su formación humanística, al pensamiento crítico y al goce estético.

Objetivos específicos:

- Reflexionará sobre las innovaciones de forma y fondo en los textos literarios a través de la lectura de obras representativas, para ubicar la literatura como quehacer humano en constante transformación.

- Comprenderá las transformaciones artísticas y sociales, su relación con sentimientos de angustia, de vacío o de ironía, así como la búsqueda del sentido de la vida, mediante el análisis de textos para vincularlos con su entorno.

- Creará textos tomando como modelo la minificción, el caligrama y/o haikú, entre otros, para generar una propuesta acorde con su realidad.

- Reconocerá la literatura como vehículo de identidad nacional y cultural, a partir de la lectura de diferentes textos para concientizar los rasgos que lo definen frente al otro.

- Comprenderá los elementos de identidad mediante el análisis de la cosmogonía, la visión del mundo, el lenguaje, la idiosincrasia y las tradiciones en los textos literarios para relacionarlos con su ideología y su contexto.

- Analizará la estructura y los elementos que conforman el ensayo, a partir de una lectura modelo para que identifique un texto de carácter argumentativo.

- Reflexionará de manera oral o escrita el tema de la otredad para manifestar su opinión con respecto a esta problemática.

- Reconocerá y comprenderá la importancia de los elementos de la naturaleza utilizados por los autores para identificar la configuración del entorno poético o del espacio a partir del análisis de diferentes textos literarios.

- Reflexionará e interpretará la influencia de la naturaleza en la vida del hombre por medio de la lectura y análisis de los textos literarios con el fin de percibirla como un espacio mágico, agreste o dominado por el ser humano.

- Creará un cuento, a partir de su experiencia lectora, para abordar el tema de la naturaleza y su influencia en la conducta humana.

- Identificará los diferentes tipos de argumentos a partir del análisis de obras representativas para comprender el discurso argumentativo.

- Comprenderá, mediante la lectura de textos literarios, la ciudad como ficción que refleja una realidad social, política, histórica, económica y moral, para tomar conciencia sobre el entorno urbano en el que se desarrolla la obra.

- Analizará el espacio literario y sus diferentes ambientes como generadores de conceptos, imágenes, historias, formas de vida, registros lingüísticos, personajes y comportamientos mediante la lectura de textos literarios para reflexionar y emitir opiniones sobre el panorama pesimista y optimista del contexto urbano.

- Redactará un texto argumentativo a partir del tema de la ciudad como pretexto para reflexionar sobre las problemáticas urbanas.

- Analizará las obras literarias que hacen referencia a la intolerancia social ya los sistemas opresores, a través de la lectura de textos representativos, para perfilarlas 


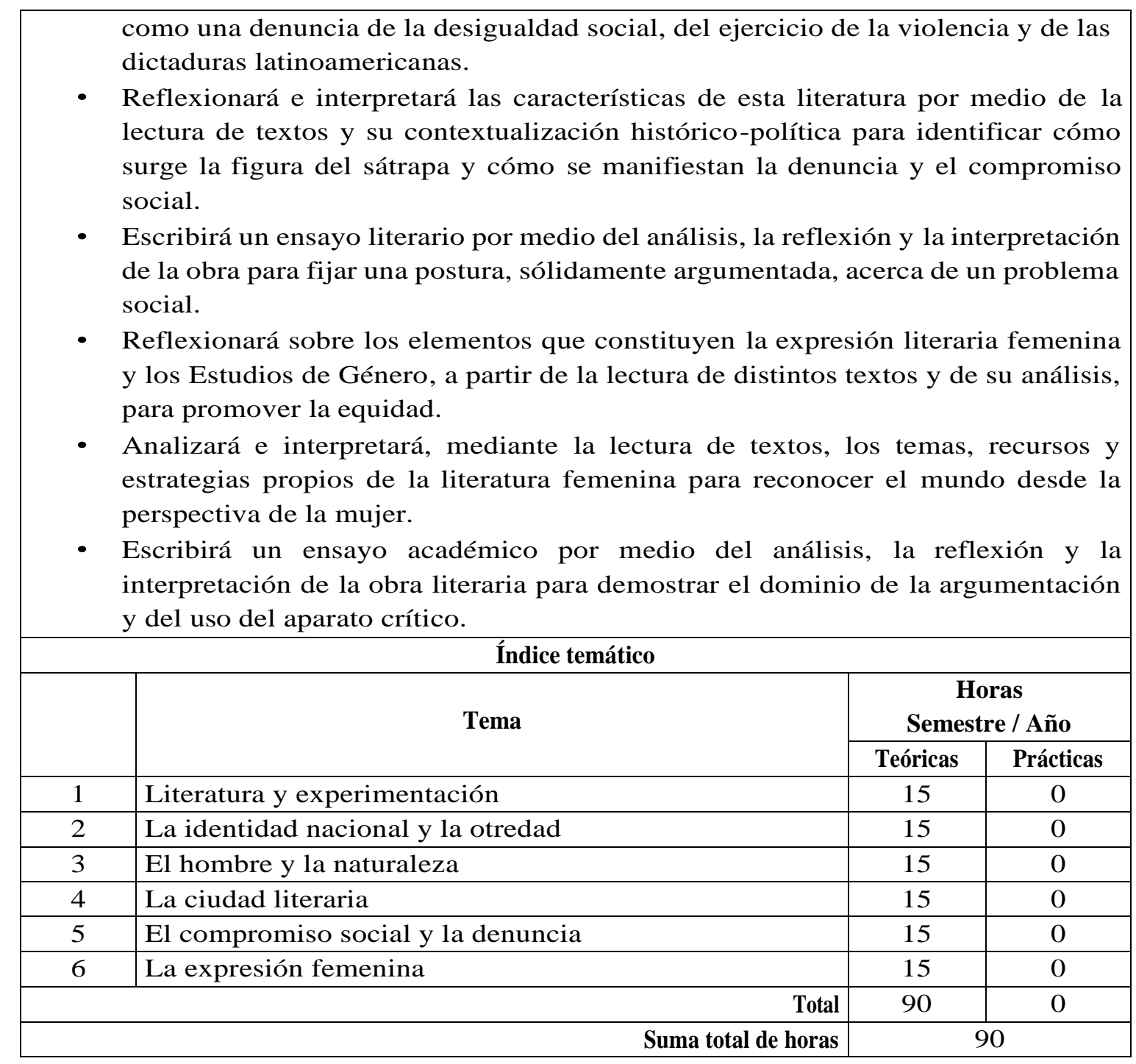




\begin{tabular}{|c|c|}
\hline \multicolumn{2}{|r|}{ Contenido Temático } \\
\hline Tema & Subtemas \\
\hline 1 & $\begin{array}{l}\text { Literatura y experimentación } \\
\text { 1.1 Realidad, ficción y verosimilitud } \\
\text { 1.2 Transformaciones de la poesía: poemínimos, caligrama, haikú, poesía en } \\
\text { prosa, entre otros: } \\
\text { a) la métrica tradicional frente a las rupturas de la forma } \\
\text { b) figuras literarias: imagen, metáfora, metonimia, sinécdoque, ironía, } \\
\quad \text { sinestesia, entre otras } \\
\text { 1.3 Innovaciones de la técnica narrativa: estructura, juegos temporales y } \\
\text { espaciales, tipo y punto de vista del narrador, monólogo interior } \\
\text { 1.4 Teatro experimental (estructura: actos, escenas, cuadros, acotaciones; trama } \\
\text { - dentro y fuera del escenario-; temas; personajes; lenguaje; interacción; } \\
\text { improvisación) } \\
\text { 1.5 Intenciones de la literatura: lúdica, crítica, social, política, entre otras }\end{array}$ \\
\hline 2 & $\begin{array}{l}\text { La identidad nacional y la otredad } \\
2.1 \text { Concepto de identidad y los elementos que la conforman } \\
2.2 \text { Lo indígena y la negritud en la poesía y la prosa: } \\
\text { a) lenguaje: neologismos, regionalismos, indigenismos, negrismos } \\
\text { b) figuras literarias: comparación, metáfora, imagen, } \\
\text { difrasismo, paralelismo, aliteración } \\
\text { c) ritmo y musicalidad } \\
\text { d) narrador y personajes } \\
\text { e) espacio y tiempo } \\
\text { 2.3 Elementos del ensayo }\end{array}$ \\
\hline 3 & $\begin{array}{l}\text { El hombre y la naturaleza } \\
\text { 3.1 Tópicos de la naturaleza en los textos literarios } \\
\text { 3.2 Figuras literarias asociadas con el entorno natural: comparación, metáfora, } \\
\text { antítesis, oxímoron, sinécdoque, hipérbole, prosopopeya, epíteto, } \\
\text { aliteración, onomatopeya } \\
\text { 3.3 La descripción de la naturaleza y su vinculación con el ser humano, como } \\
\text { espacio mágico, agreste o dominado por el individuo } \\
\text { 3.4 El cuento } \\
\text { 3.5 Tipos de argumentos: de autoridad, personal, sentido común, analógico, } \\
\text { entre otros }\end{array}$ \\
\hline 4 & $\begin{array}{l}\text { La ciudad literaria } \\
\text { 4.1 El espacio urbano y su significación en la literatura: la verosimilitud del } \\
\text { espacio físico } \\
\text { 4.2 La construcción del espacio: físico, histórico, simbólico, psicológico, } \\
\text { imaginario } \\
\text { 4.3 La descripción del espacio: lo público y lo privado } \\
\text { 4.4 El espacio y su vinculación con el personaje } \\
\text { 4.5 El texto argumentativo }\end{array}$ \\
\hline
\end{tabular}




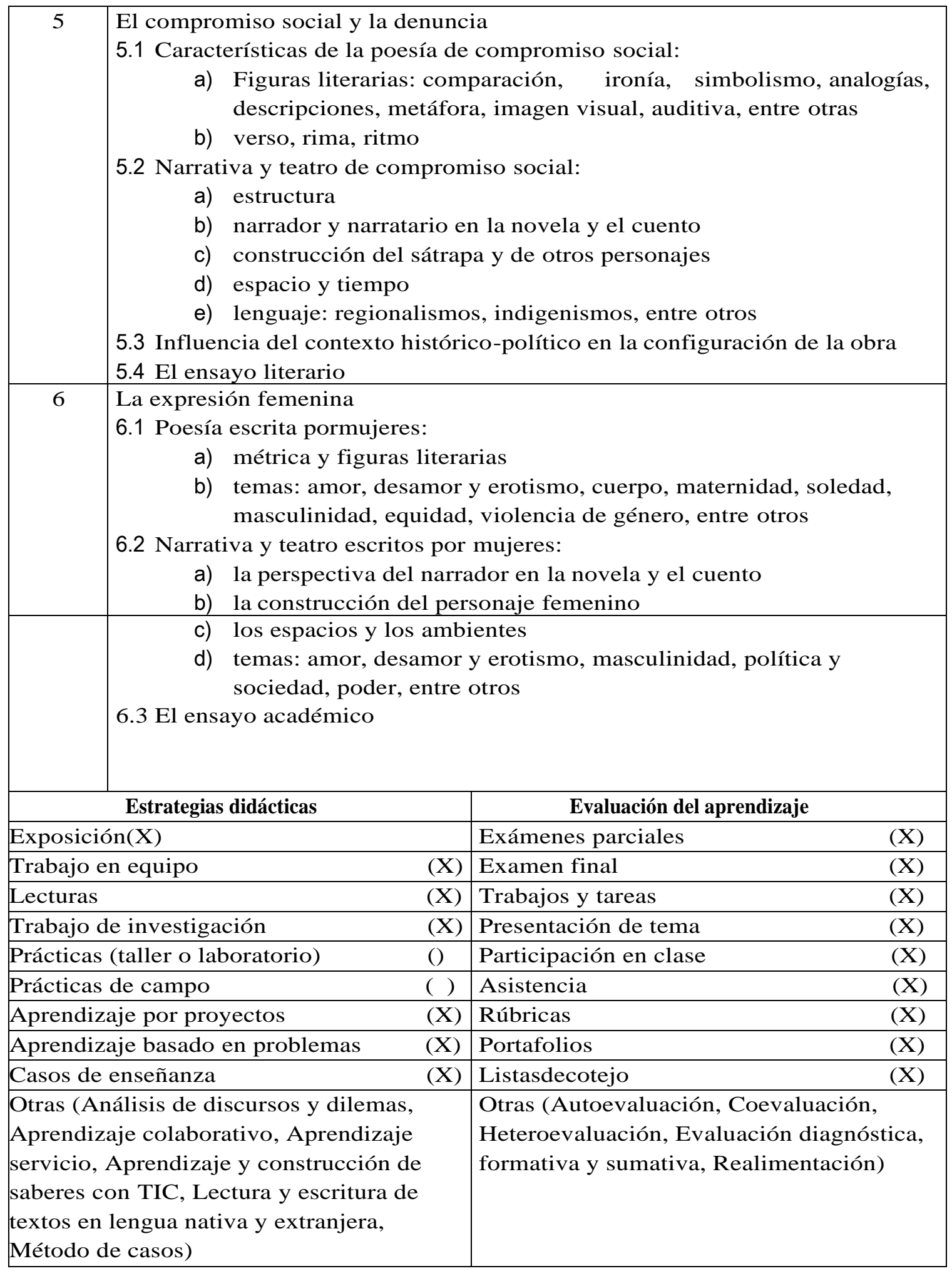




\begin{tabular}{|c|c|}
\hline Título o grado & $\begin{array}{l}\text { Contar con un promedio mínimo de } 8 \text { (ocho) y con título en: } \\
\text { Licenciado en: Lengua y literatura(s) hispánicas, Letras Hispánicas, } \\
\text { Escritura creativa y literatura, Letras Clásicas. Maestro o Doctor en } \\
\text { Letras: Latinoamericanas, Mexicanas, Españolas, Lingüística, } \\
\text { Humanidades: Literatura o Teoría Literaria. Docencia para la } \\
\text { enseñanza Media Superior en Español (MADEMS). Maestro } \\
\text { Normalista con especialidad en la enseñanza del español y con } \\
\text { estudios de posgrado en: letras españolas, } \\
\text { latinoamericanas, mexicanas y lingüística. }\end{array}$ \\
\hline $\begin{array}{l}\text { Experiencia docente } \\
\text { (deseable) }\end{array}$ & $\begin{array}{l}\text { Se recomienda contar con experiencia en docencia y demostrar las } \\
\text { siguientes habilidades y actitudes necesarias para impartir la } \\
\text { asignatura: Dominar y conocer de la disciplina. Planificar el proceso } \\
\text { de enseñanza- aprendizaje, seleccionando y preparando los } \\
\text { contenidos de la disciplina y las estrategias didácticas para } \\
\text { abordarlos, así como los instrumentos de evaluación. Emplear } \\
\text { estrategias didácticas adecuadas para el aprendizaje en grupos } \\
\text { numerosos. Conocer las características psicológicas del adolescente. } \\
\text { Establecer una comunicación clara con los estudiantes. Conocer la } \\
\text { aplicación didáctica de las Tecnologías de la Información y la } \\
\text { Comunicación (TIC). Seleccionar el material didáctico que propicie } \\
\text { el hábito lector. Actuar de manera positiva para propiciar la reflexión } \\
\text { en el aula. Estar dispuesto para el trabajo interdisciplinario, } \\
\text { colaborativo, de investigación y de aprendizaje. }\end{array}$ \\
\hline Otra caracterí & $\begin{array}{l}\text { Cumplir con los requisitos de ingreso y permanencia que marca el } \\
\text { Estatuto del Personal Académico (EPA) de la UNAM, con las } \\
\text { cláusulas del Sistema de Desarrollo del Personal Académico } \\
\text { (SIDEPA) y los requerimientos que emanen de las disposiciones del } \\
\text { Consejo Técnico de la ENP. }\end{array}$ \\
\hline
\end{tabular}




\section{Bibliografía básica:}

Ballester, J. (2015). La formación lectora y literaria. Barcelona: Graó

Bordons, G. y Díaz-Plaja, A. (coords.). (2006). Enseñar literatura en secundaria. La formación de lectores críticos, motivados y cultos. Barcelona: Graó.

Camps, A. (2008). Secuencias didácticas para aprender a escribir.

Barcelona: Graó. Cassany, D. (2012). En_línea. Leer y escribir en la red. Barcelona: Anagrama.

García Barrientos, J. L. (2007). Análisis de la dramaturgia. Nueve obras y un método. Madrid: Fundamentos.

Jover, G. (coord.) (2009). Constelaciones literarias. Sentirse raro. Miradas sobre la adolescencia. Málaga: Consejería de educación de la Junta de Andalucía. Recuperado de: http://www.juntadeandalucia.es/educacion/webportal/abacoportlet/content/0 $15 \mathrm{af} 83 \mathrm{c}-3362-4 \mathrm{f} 74-929 \mathrm{c}-\mathrm{af} 321 \mathrm{e} 6 \mathrm{e} 6 \mathrm{f} 36$

Larrosa, J. (2000). La experiencia de la lectura. Estudios sobre la literatura y formación. México: F.C.E.

Lomas, C. (2014). La educación lingüística, entre el deseo y la realidad. Competencias comunicativas y enseñanza del lenguaje. México: Flacso/Octaedro. lenguaje. Barcelona: Graó

Masó, J. (ed.) (2008). Escrituras de la sexualidad. Barcelona: Icaria Moreno, V. (2004). El deseo de escribir. Propuesta para despertar y mantener el gusto por la escritura. México: Ediciones Alejandría/Pamiela.

----------- (2011). Cómo hacer lectores competentes. Guía práctica: reflexiones y propuestas.

México: Ediciones Alejandría/Pamiela.

Petit, M. (2009). El arte de la lectura en tiempos de crisis.

México: Océano. Pimentel, L. A. (1998). El relato en

perspectiva. México: UNAM/Siglo XXI.

------- (2001). El espacio en la ficción. México:

UNAM/Siglo XXI. Rosenblatt, L. M. (2002). La Literatura como

exploración. México: F.C.E. Solé, I. (2007). Estrategias de

lectura. Barcelona: Graó.

Spang, K. (1993). Géneros literarios. Madrid: Síntesis.

------------ (2012). Teoría del drama. Lecturas y análisis de la obra teatral. Madrid:

Euns.

Strauss, B. (2006). Crítica teatral: las nuevas fronteras: análisis de los acontecimientos estéticos y políticos involucrados en la acción teatral. Barcelona: Gedisa.

Tomás, N. T. (2004) Arte del verso. Madrid: Visor libros. 


\section{Obras literarias sugeridas}

A continuación, se proponen una serie de autores y lecturas, el criterio de selección obedece a la temática y a las constelaciones literarias que se trabajan en cada unidad. La relación no es restrictiva ni exhaustiva, por lo tanto, hay libertad de elegir las lecturas más apropiadas.

\section{Unidad 1}

Argudín, Antonio, Sueldo según capacidades.

Arlt, Roberto, Teatro completo.

Arredondo Inés, Obras completas.

Bioy Casares Adolfo, Historias fantásticas, Historias de amor.

Borges Jorge Luis, El libro de arena, El informe de Brodie.

Brull, Mariano, Obras Poesía y Prosa: 1916-1955.

Buenaventura, Enrique, Aladino y la lámpara maravillosa, La autopsia

Cabrujas, José Ignacio, El día que me quieras. Cáceres Omar, Defensa del ídolo.

Carballido, Emilio, Te juro Juana que tengo ganas.

Conrado, Nalé Roxlo, Judith y las rosas.

Cortázar Julio, Todos los fuegos el fuego, Octaedro, La otra orilla.

Díaz, Jorge, Mata a tu prójimo como a ti mismo, Acerca de la libertad, los

elefantes y otras zoologías.

Dragún, Osvaldo, Historia del hombre que se convirtió en perro.

Gallardo, Salvador, Antología inconclusa.

Garro, Elena, Un hogar sólido.

González; Rojo Enrique, Criaturas de la tinta alada.

González; Rojo Enrique, Romance de José Conde.

Hernández Felisberto La casa inundada, Las hortensias.

Hernández, Luisa Josefina, Los huéspedes reales.

Huidobro, Vicente Obra poética.

Licona, Alejandro, Cómo pasar matemáticas sin problemas, Cuentas por cobrar.

Liera, Oscar, El jinete de la Divina providencia.

Lomelí, Luis Felipe, Indio borrado, Ella sigue de viaje.

López, Willebaldo, Cosas de muchachos.

Magaña, Esquivel Antonio, Teatro mexicano del siglo XX.

Maples, Arce Manuel, Las semillas del tiempo: obra poética, "Prisma".

Monterroso, Augusto, La palabra mágica.

Novo Salvador, Poesías escogidas.

Oliverio Girondo, Espantapájaros, Persuasión de los días, Interlunio.

Ortíz de Montellano Bernardo, Red, Sueños.

Paz Octavio, Libertad bajo palabra, Topoemas, Discos visuales.

Rebolledo, Efrén, Estela, Caro victrix.

Ruvalcaba, Eusebio, La visita.

Sabdiel, Yéred, La espantosa y marginal vida de Godzilla. 
Sada, Daniel, Casi nunca, Antología presentida.

Salazar, Bondy Sebastián, No hay isla feliz.

Samperio Guillermo, Antología personal.

Torri, Julio, De fusilamientos; Prosas dispersas, Ensayos y poemas.

Triana, José, La noche de los asesinos.

Usigli, Gorostiza, Villaurrutia, Novo, Vicente Leñero, Luis G. Basurto,

Julio Castillo. Carlos Solórzano; Héctor Mendoza, Jesús González Dávila.

Valenzuela, Teresa, Estela y la geografía política.

Vallejo, César, Escalas melografiadas, Fabla salvaje, Heraldos negros.

Villegas, Oscar, La Pira.

\section{Unidad 2}

Agustín Yánez, Al filo del agua.

Arguedas José María, Yawar fiesta.

Asturias Miguel Ángel, Hombres de maíz.

Bañuelos Juan "Instantáneas de una estela maya” Vivo, eso sucede: poesía reunida.

Cardenal Ernesto, Canto nacional, Las ínsulas extrañas.

Cardoza y Aragón, Luis "Paisaje de Coatlicue".

Cross Elsa, Visible y no.

Dauajare, Félix, Definiciones; poemas.

Galeano Eduardo, Las venas abiertas de América Latina, Patas arriba La escuela del mundo al revés, Los hijos de los días.

Lugones Leopoldo, El Payador.

Martínez Tomas Eloy, Santa Evita.

Magaña Sergio, "Moctezuma II".

Piglia Ricardo, Respiración artificial, Plata quemada.

Revueltas José, El luto humano

Rojas González Francisco El Diosero y todos los cuentos.

Rodríguez Galván Ignacio, "Profesía de Guatimoc", "La visión de Moctezuma".

Traven Bruno Canasta de cuentos mexicanos.

\section{Unidad 3}

Abreu, Gómez, Emilio, Canek

Acuña, Manuel, Poemas.

Alegría, José Ciro, Leyendas.

Amado, José Mar muerto, Los viejos marinos.

Asturias, Miguel Ángel Cuentos, Hombres de maíz, Mulata de tal.

Asunción, Silva José, Obra poética.

Bello, Andrés, Silvas.

Borges, Jorge Luis, Luna de enfrente, Historia de la noche.

Carpentier, Alejo, Cuentos.

Casal, Julián de, Poemas.

De la Vega, Garcilaso "El Inca”, La Florida.

Echeverría, Esteban, La cautiva. 
Fernández de Oviedo, Gonzalo, Historia general y natural de las indias.

Joseph de Acosta, Historial natural y moral de las Indias.

Gallegos, Rómulo Cuentos completos.

García, Márquez Gabriel, Cuentos, La hojarasca, El amor en los tiempos del

cólera.

González, Martínez Enrique, El romero alucinado.

Gorostiza, José, Canciones para cantar en las barcas.

Guillén, Nicolás, Motivos del son, Sones para turistas y España.

Hernández, José, Martín Fierro.

Ibarbourou, Juana de Lenguas de diamante, "Como la primavera", "Raíz salvaje".

Icaza, Jorge, Relatos, Cholos.

Landívar, Rafael, Rusticatio mexicana.

Lezama, Lima Cuentos.

Lezama, Lima José, Aventuras sigilosas, Dador.

Neruda, Pablo, Crepusculario; Veinte poemas de amor y una canción

desesperada.

Nervo, Amado, Los jardines interiores.

Onetti, Juan Carlos Tierra de nadie.

Othón, José María, Nuevas poesías.

Owen, Gilberto, "El naufragio", "Espera octubre"; Perseo vencido.

Revueltas, José Dormir en tierra, El luto humano.

Rivera, José Eustasio, Tierra de promisión.

Roa Bárcenas, José María y Riva Palacio, Vicente, Tradiciones y Leyendas

mexicanas.

Sierra, Justo, Cuentos románticos.

Torres, Bodet Jaime, Trébol de cuatro hojas.

Uslar, Pietri Arturo, La lluvia y otros cuentos, Treinta cuentos.

Vargas Llosa Mario La casa verde, Lituma en los Andes.

Von Humboldt, Alejandro, Vistas de las cordilleras y monumentos de los pueblos indígenas de América.

\section{Unidad 4}

Agustín, José, Círculo vicioso.

Campo, Ángel de Ocios y apuntes, Cosas vistas y cartones. Cuellar,

José Tomás de, Ensalada de Pollos, Los fuereños. Fernández de

Lizardi José Joaquín, Don Catrín de la Fachenda. Hernández,

Francisco, La isla de las breves ausencias

González, Obregón, Luis, México viejo.

Licona, Alejandro, Cómo pasar matemáticas sin problemas.

Morabito, Favio, La vida ordenada.

Pacheco, José Emilio, El viento distante.

Sainz, Gustavo, La princesa del Palacio de Hierro.

Usigli, Rodolfo, El gesticulador. 
Monsiváis, Carlos. (1980) A ustedes les consta. Antología de la crónica en México.

\section{Unidad 5}

Aguilera Malta, Demetrio, Canal zone. Alegría

Ciro, Los perros hambrientos. Ampuero Roberto,

Nuestros años verde olivo.

Arenas Reinaldo, Arturo, La estrella más brillante, Antes que anochezca.

Arévalo Martínez Rafael "Las fieras del trópico".

Ascencio Segura Manuel, El sargento Canuto. Azuela

Mariano, Mala yerba.

Barba Jacob, Porfirio, Rosas negras.

Barquero, Efraín, "Los sacrificados" “Galopan las patrullas" "El cazador”.

Basurto Luis G., El candidato de Dios.

Belli Carlos Germán, "A modo de un pintor primitivo culto", "mamá, papá".

Berenguer Amanda, "No quieres venir a llorar conmigo", El río y otros poemas.

Blanco Fombona Roberto, "Democracia criolla.

Blest Gana Alberto, Martín Rivas.

Bombal María Luisa, "El árbol”.

Bosch Juan, Camino real.

Cabello Mercedes Carbonera, El conspirador.

Cadenas Rafael, Antología, 1958-1983, Obra entera: poesía prosa, 1958-1995.

Cardenal Ernesto, Antología.

Carpentier Alejo "El acoso", El recurso del método.

Chamorro Joaquín, Cuentos.

Conrado Nalé Roxlo Judith y las rosas.

Constantini Humberto, Cuestiones con la vida: Antología poética.

Cortázar Julio, "Segunda vez".

Díaz Eterovic Ramón, La ciudad está triste, Los siete hijos de Simenon

Dragún Osvaldo, Tupac Amaru. Electorat

Mauricio, La burla del tiempo. Estrada

Antonio, Rescoldos.

Fernández de Lizardi José Joaquín, El Periquillo Sarniento El unipersonal de

Agustín de Iturbide.

Fernández Retamar Roberto, Felices los normales: poesías escogidas, 1949-

1999.

Ferré Rosario, "La bella durmiente", Maldito amor.

Fonseca Rubem, Pasado Negro, Agosto.

Fuentes Carlos, La muerte de Artemio Cruz.

Gallegos Rómulo, El forastero.

García Márquez Gabriel, El otoño del Patriarca.

Garro Elena Y Matarazo no llamó.

Gerbasi Vicente, Los espacios cálidos y otros poemas, Antología poética, 1943 1968.

Giardinelli Mempo, Luna caliente. 
González Otto Raúl, Los Hermosos animales, Huitziluantuxtli. Colibrí y Conejo.

González Prada Manuel, Horas de lucha.

González Tuñón Raúl, "De pronto entró la libertad”, "El poeta murió al amanecer”.

Hernández José, Martín Fierro, La vuelta de Martín Fierro.

Herrera Ernesto, El león ciego.

Hinostroza Rodolfo, Poesía completa, Consejero del lobo.

Ibargoyen Saúl, El poeta y yo, Junta versos, Gran cambalache, La última

bandera.

Ibargüengoitia Jorge, Maten al león.

Jamís, Fayad, Abrí la verja de hierro, Los puentes.

Lacunza José María, Netzula.

Laforucade Enrique, La fiesta del rey Akab.

Lara Zavala Hernán, Charras.

Lavín Cerda Hernán Tal vez un poco de eternidad, Divagaciones del pequeño

filósofo.

Lazo Olegario, Cuentos militares.

Lihn Enrique, Al bello aparecer de este lucero, La pieza oscura.

López Willebaldo, Cosas de muchachos.

Mármol José, Amalia.

Mateos Juan A., El cerro de las campanas. Memorias de un guerrillero.

Matto de Turner Clorinda, Aves sin nido.

Miguel Ángel, El señor Presidente.

Montalvo Juan, Las catilinarias.

Montemayor Carlos, La guerra en el paraíso.

Nieto Cadena Fernando "Coincidimos en confundir la historia", "Somos asunto de muchísimas personas".

Olvera Omar, Para la libertad.

Onetti, Juan Carlos Junta cadáveres.

Padura Fuentes Leonardo, Paisaje de Otoño.

Parra Nicanor, Sermones y prédicas del Cristo de Elqui, Hojas de Parra.

Pasos Joaquín, Canto de guerra de las cosas y otros poemas.

Payró Roberto J., "Probidad".

Pedroso Regino, Antología de la poesía cósmica de Regino Pedroso.

Piñera Virgilio, Electra Garrigó.

Portogalo José, Entre los poetas míos.

Posse Abel, Los perros del paraíso.

Prieto Guillermo, Memorias de mis tiempos. Ribeyro

Julio Ramón, "Los gallinazos sin plumas". Riva

Palacio Vicente, Calvario y Tabor.

Roa Bastos Augusto, Yo el supremo.

Rodó José Enrique, Ariel.

Rojas Guardia Armando, Del mismo amor ardiendo.

Rokha Pablo de, Epopeya de las comidas y bebidas de Chile.

Sábato Ernesto, Sobre héroes y tumbas, Abaddón, el exterminador. 
Sarmiento Domingo Faustino, Facundo.

Sebastián Salazar Bondy, No hay isla feliz.

Soriano Osvaldo, Cuarteles de invierno.

Taboada Terán Néstor, La tempestad y la sombra.

Urbaneja Achelphol Luis Manuel, "El ancestro".

Uslar Pietri Arturo, Oficio de difuntos.

Vargas Llosa Mario, Los cachorros, Conversación en La

Catedral. Vergara José María, "Consejos a mi potro".

Vicente Leñero, Dramaturgia terminal.

Zalamea Jorge, El gran Burundum-Burundá ha muerto.

Zarco Francisco "El Palacio Nacional".

Zepeda Patterson Jorge, Los corruptores.

\section{Unidad 6}

Aguirre, Isidora, Los que van quedando en el camino.

Algarra, María Luisa, Casandra o La llave sin puerta.

Amor, Guadalupe, Yo soy mi casa.

Arredondo, Inés, Obras completas.

Azcárate, Leonor, Las alas del poder.

Azcona Cranwell, Elizabeth, Imposibilidad del lenguaje o los nombres del amor.

Beltrán, Rosa, La corte de los ilusos.

Berman, Sabina, La mujer que buceó en el corazón del mundo.

Boullosa, Carmen, Los totoles, Todos los amores: antología de poesía amorosa.

Bracho, Coral, Huellas de luz.

Buitrago, Fanny, Señora de la Miel.

Burgos, Julia de, Poemas en veinte surcos.

Caballero de Castillo Ledón, Amalia, Cuando las hojas caen.

Camarillo, María Enriqueta, Rincones románticos.

Campos, Julieta, Muerte por agua.

Campobello, Nellie, Cartucho.

Castellanos, Rosario, Los convidados de agosto, El eterno femenino.

Cross, Elsa, Amor el más oscuro.

Cruz, Sor Juana Inés de la, Obras completas.

Dávila, Amparo, Cuentos reunidos.

Eltit, Diamela El padre mío.

Esquivel, Laura, Como agua para chocolate.

García Bergua, Ana, La bomba de San José.

Garro, Elena, La señora en su balcón.

Glantz, Margo, Síndrome de naufragios.

Gómez de Avellaneda, Gertrudis, Poesías líricas.

González de León, Ulalume, Plagios.

Gramcko, Ida, Sol y soledades.

Grijalva, Dina, Las dos caras de la luna.

Guido, Beatriz Fin de fiesta. 
Hernández, Luisa Josefina, La cólera secreta, Los frutos caídos

Ibarbourou, Juana de, Las lenguas del diamante.

Jacobs, Bárbara, Las hojas muertas.

Krauze, Ethel, El secreto de la infidelidad

Lair, Clara, Trópico amargo.

Laoeza, Guadalupe, Niñas mal.

López Colomé, Pura, Poemas reunidos.

López Mills, Tedi, Un jardín, cinco noches (otros poemas).

Macías, Elva, Imperio móvil.

Méndez de Cuenca, Concha, Simplezas.

Mistral, Gabriela, Desolación.

Moscona, Myriam, El que nada.

Ocampo, Silvina, La promesa.

Orozco, Olga, La noche a la deriva.

Pettersson, Aline, Colores y sobras. Tres novelas.

Peralta, Bertalicia, Atrincherado amor. Peri

Rossi, Cristina, Cuentos reunidos. Pizarnik,

Alejandra, Obra completa.

Poniatowska, Elena, Hasta no verte Jesús mío.

Puga, María Luisa, Los siete pecados capitales.

Sada, Concepción, Como yo te soñaba.

Sefchovich, Sara, Demasiado amor.

Seligson, Esther, Toda la luz.

Serrana, Elisa, Chilena, casada, sin profesión. Serrano,

Marcela, Nosotras que nos queremos tanto. Storni,

Alfonsina, La inquietud del rosal.

Urueta, Margarita, El hombre y la máscara, El señor perro.

Valenzuela, María Luisa, Cola de lagartija.

Varela, Blanca, Ese puerto existe.

Vicens, Josefina, El libro vacío.

Vilalta, Maruxa, El otro día, la muerte.

Volkow, Verónica, Litoral de tinta y otros poemas 


\section{Bibliografía}

Agnew Jean-Christophe, "Review on Descent into Discourse. The Reification of Language and the Writing of Social History by Bryan D. Palmer" Arguing that the current reliance on poststructuralism obscures the origins, meanings and consequences of historical events and processes. Temple University. https://www.temple.edu/tempress/titles/648_reg_print.html(Consultada 31-01$18)$.

Arceo-Gomez, Eva O., Campos-Vazquez, Raymundo M. "Teenage Pregnancy in Mexico: Evolution and Consequences" Latin American journal of economics. Mayo 2014. No.1. Vol.51, Santiago. https://scielo.conicyt.cl/scielo.php?script=sci_arttext\&pid=S071904332014000100004 (consultada 05-03-2019)

Arzate Heredia, Christian Esau. Elementos teóricos y metodológicos para la incorporación de la perspectiva de género en el Currículum Universitario. Tesis de Licenciatura, Universidad Nacional Autónoma de México. 2012.

Atwood, Margaret. Strange Things: The Malevolent North in Canadian Literature. Hachette Digital. 2009.

La Santa Biblia. Ediciones Paulinas, 23 edición, Madrid,

Ballester, Josep. Ibarra, Noelia. "La tentación diabólica de instruirse. Reflexiones a propósito de la educación lectora y literaria" Ocnos, 10.P. 7-26. http://www.revista.uclm.es/index.php/ocnos/article/view/238 (consultada 0503-2018)

Barry, Ellen. Desaprender el género desde preescolar. New York Times. 27/03/2018. https://www.nytimes.com/es/2018/03/27/suecia-educacion-tempranagenero/?rref=collection\%2Fsectioncollection\%2Fnyt-es (consultada el_30-032018)

Bordieu, Pierre. "Estrategias de reproducción y modos de dominación”. Colección pedagógica Universitaria. enero-junio/julio-diciembre 2002. No. 37-38.

La dominación masculina.Barcelona,Anagrama, 2000.

Brouns, M. "Gender and the Assessment of Scientific quality" European Commission. 2004, pp$147-154$

Butler, Judith. Gender in Trouble. Feminism and the Subversion of Identity. Nueva York,Routledge, 1990.

Camarena Adame, María Elena. y Saavedra García, María Luisa. "La perspectiva de género en los programas de estudio de las licenciaturas contables administrativas" Revista Noesis. Revista de Ciencias Sociales y Humanidades, Julio-Diciembre 2018. Vol. 27.

Cardaci, Dora., Goldsmith, Mary. y Parada-Ampudia, Lorenia. "Los programas y centros de estudios de la mujer y de género en México" Feminismo en México Revisión histórico-crítica del siglo que termina, México D.F.,Programa Universitario de Estudios de Género, Universidad Nacional Autónoma de México. 2002.

Caballero, Álvarez Rebeca. "El diseño curricular como estrategia para la incorporación de la perspectiva de género en la educación superior" Revista Latinoamericana de Estudios Educativos(México), Centro de Estudios Educativos, A.C. Distrito Federal, México. vol XLI, núm 3-4, 2011, pp 45-64. F 
Castillo, Gabriela. Una sola mujer hace el mapa más detallado de feminicidios en México. https://plumasatomicas.com/noticias/una-sola-mujer-hace-el-mapa-mascomprensivo-de-feminicidios-en-mexico/

Centro de Información de la Naciones Unidas. México Cuba y República Dominicana. http://www.cinu.mx/noticias/la/violencia-contra-mujeres-y-nin/(Consultado 0603-2017)

Chambers, Adain. Dime: Los niños, la lectura y la conversación. México D.F., Fondo de Cultura Económica. 2015.Pp. 166.

Cortés, Pérez María Inés. "La perspectiva de género: una propuesta didáctica para enriquecer la literatura en el bachillerato" 2017

Del tronco Paganelli, José y Madrigal Ramírez, Abby. "Violencia escolar en México: una exploración de sus dimensiones y consecuencias. Revista de trabajo Social UNAM. Pp. 24-42.

Díaz y de Ovando, Clementina. El Colegio Máximo de San Pedro y San Pablo. México D.F. 1951. Instituto de Investigaciones Estéticas Ediciones del VI Centenario de la Universidad de México.

European Commission, Community Research. Gender and Excellence in the Making. Study. 2004.http://europa.eu.int/comm/research/rtdinfo_en.html(consultada 06-032017)

European Commission, Directorate-General for Research. Gender and Excellence in the Making.2004.

European Commission, Community Research, She Figures 2015. https://ec.europa.eu/research/swafs/pdf/pub_gender_equality/she_figures_2015 -final.pdf(Consultado 06-03-2017)

Falu, Ana. "Gender perspectives in urban planning" UNOHABITAT. For a better urban future. https://unhabitat.org/gender-perspectives-in-urban-planning-anafalu/?fbclid=IwAR18SnRW1QN2FnjJQi0yvAzZyTNeXVF0r9RbX3p9XwwJuiYErBW8cdJ0-k (consultada el 04 de marzo de 2019)

Galaviz, Nadia. "Somos afromexicanos" Desinformémonos periodismo de abajo. Universidad Autónoma Metropolitana.Iztapalapa. 2017 https://desinformemonos.org/somos-afromexicanos/ (consultado el $04 \mathrm{de}$ marzo de 2019)

García Prince, Evangelina. Políticas de Igualdad, Equidad y Gender Mainstreaming ¿de qué estamos hablando?: Marco Conceptual. Programa de las Naciones Unidad para el Desarrollo PNUD América Latina Genera: Gestión del conocimiento para la equidad de género en Latinoamérica y El caribe. San Salvador 2008.

Girolamo, Furio. "L’ideologia del "gender": se la conosci la eviti." Diaconi, Foglio Notizie del Diaconato della Diocesi di Roma. http://www.vicariatusurbis.org/diaconatus/_nuovo/articoli/formazione/formazi one0911.asp(consultada 31-01-2018).

Golubov, Nattie. La critica literaria feminista. Una introducción práctica.

México.D.F.Facultad de Filosofía y Letras, Universidad Nacional Autónoma de México, 2012.

González Jiménez, Rosa María. "Presentación. Estudios de Géneros en educación: una rápida mirada." En 
Revista mexicana de investigación educativa, jul/sep 2009.Vol. 14, no. 42. http://www.scielo.org.mx/scielo.php?script=sci_arttext\&pid=S140566662009000300002(Consulta realizada 19-02-2018)

Güezmes, Ana. "Violencia contra las mujeres y niñas, pandemia mundial" CINE Centro de Información de las Naciones Unidas. México, Cuba y República Dominicana. 24,11,2016. http://www.cinu.mx/noticias/la/violencia-contra-mujeres-y-nin/ (consultada 04-03-2019)

Hierro Graciela. "Madres simbólicas del feminismo en México" Feminismo en México Revisión histórico-crítica del siglo que termina. México. D.F. Programa Universitario de Estudios de Género, Universidad Nacional Autónoma de México, 2002.

Hooper, John. y Branigan, Tania. "Pope warns feminists. Bishops told to take hard line on issue of gender" The Guardian World news Europe 31 Jul 2004.

https://www.theguardian.com/world/2004/jul/31/gender.catholicism(Consultad a 31-01-18).

Instituto Nacional de Estadística y Geografía. Población, Relación hombres-mujeres. http://www.beta.inegi.org.mx/temas/estructura/(Consultada 31-01-18)

Jaschik, Scott. "Indiana Creates First Gender Studies Ph.D.” Inside Higher Ed. https://www.insidehighered.com/news/2005/11/10/gender(Consultada 31-0118).

Jover, Guadalupe. Constelaciones literarias. Sentirse raro. Miradas sobre la adolescencia. Malaga,Libro Abierto, 2009.

. "Para que quepamos las mujeres habrá que cambiar los marcos". El diario de la educación. http://eldiariodelaeducacion.com/blog/2018/02/28/quepamos-lasmujeres-habra-cambiar-los-marcos/ (consultada 04-03-2019)

Korolczuk, Elżbieta. "The Vatican and the Birth of Anti-Gender Studies" Religion \& Gender. 2016. Vol.6, no.2, pp. 293-296.

Labrador Herraiz, Carmen. "La Ratio Studiorum de 1599. Un sistema educativo singular" Revista de Educación, 1999. No. 319, pp. 117-134.

Lamas, Marta. ¿De qué hablamos cuando hablamos de género? curso en línea, Grandes Maestros de la UNAM, Universidad Nacional Autónoma de México. http://www.grandesmaestros.unam.mx/curso-disponible/de-que-hablamoscuando-hablamos-de-genero/(Consultada 31-01-18)

Lara, Catalina. "La perspectiva de Género en los sistemas de evaluación de la producción científica" Revista de Investigación Educativa, 2007, Vol.25, No. 1, pp. 133148.

Lombardo, Emanuel. "El mainstreaming de género en la Unión Europea" Aequalitas. Revista Jurídica de Igualdad de Oportunidades entre Mujeres y Hombres. MayoDiciembre 2003. vol. 10-15, pp. 6-11

Marinsalta, Claudia Irene. "Cuestionando las ausencias en el currículo universitario" Congreso internacional: Las políticas de equidad de género en prospectiva: nuevos escenarios, actores y articulacionesárea de Género, Sociedad y Políticas, Noviembre, 2010. FLACSO Argentina.

Macdonald, Amie. Twenty-first-century feminist classrooms: pedagogies of identity and difference. Nueva York, Palgrave Macmillan, 2002.

Martin, Tom. "You can't deny it. Gender studies is full of male-blaming bias." The Guardian, Gender Opinion, 14 de sept. de 2011. 
https://www.theguardian.com/commentisfree/2011/sep/14/gender-studies-maleblaming-bias (Consultada 31-01-18)

Meneses Morales, Ernesto. Tendencias Educativas Oficiales en México, 1821-1911. México, Porrúa, 1983, p. 194.

Messer Davidow, Ellen. Disciplining feminism: from social activism to academic discourse. Durnham,Duke University, 2002.

Moreno, Hortensia.https://www.lai.fu-berlin.de/es/e-

learning/projekte/frauen_konzepte/projektseiten/konzeptebereich/mo_literatura_femenina/conte xto/index.html(Consultada 31-01-18).

Najar, Alberto. y Paullier, Juan. "Ecatepec: cómo es vivir en el peor lugar para ser mujer de todo México. BBC Mundo, 21 de sept. de 2015.

http://www.bbc.com/mundo/noticias/2015/09/150831_mexico_feminicidios_ecatepec_violenci a_mujeres_jp(consultado 05/12/2016)

Newsome, John. "Pope warns of 'ideological colonization' in transgender teachings" CNN, International Edition, October 4, 2016. http://edition.cnn.com/2016/10/02/world/pope-transgendercomments/(consultada 31-01-2018)

New York Times https://www.nytimes.com/es/2018/03/27/suecia-educacion-tempranagenero/?rref=collection\%2Fsectioncollection\%2Fnyt-es

Patternotte, David. "Christian Trouble: The Catholic Church and the Subversion of Gender". CritCom A Forum for Research \& Commentary on Europe.http://councilforeuropeanstudies.org/critcom/christian-trouble-thecatholic-church-and-the-subversion-of-gender/

Pereira, Armando., Claudia, Albarrán., et al. "Literatura escrita por mujeres" Enciclopedia de la literatura en México. 2004, Fundación para las letras mexicanas, Secretaría de cultura. http://www.elem.mx/estgrp/datos/94 (consultada el 04 de marzo de 2019)

Pilcher, Jane.y Whelehan, Imelda. Fifty Key Concepts in GenderStudies.Londres,Sage Publications, 2004.

Ramírez Grajeda, Beatriz. "La identidad como construcción de sentido"Andamios.2017. Universidad Autónoma de la Ciudad de México. Vol. 14, Núm. 33.

San Diego State University, Department of Women's Studies, College of arts \& Letters. http://womensstudies.sdsu.edu/history.htm(Consultada 19-02-2018).

Sanjuan Álvarez, Marta. "Leer para sentir. La dimensión emocional de la educación literaria" Impossibilia30 de octubre 2014. No8, Universidad de Zaragoza. P.p. 155-178.

Scott, Joan. Género e historia.CDMX, Fondo de Cultura Económica, 2008.

Secretaría de Educación Pública. Aprendizajes Clave para la Educación Integral. Lengua Extranjera. Inglés. Educación básica. Plan y programas de estudio, orientaciones didácticas y sugerencias de evaluación. CDMX. 2017.

Secretaría de Gobernación. ¿Qué es la identidad de Género?. Secretaría de Gobernación Blog. https://www.gob.mx/segob/articulos/que-es-la-identidad-de-genero(consultada 4-02- 2018)

Segato, Rita. foro CLACSO. 2018. https://www.youtube.com/watch?v=e_b7TC1Jbto (consultada04-03-2019)

Sinay, Sergio. La masculinidad tóxica. Un paradigma que enferma a la sociedad y amenaza a las personas. Buenos Aires, Ediciones B, 2006.

St. Pierre, Elizabeth y Pillow, Wanda S. Working the ruins: feminism poststructural 
theory and methsds in education. Nueva York,Routledge, 2000.

Solana, Fernando y Cardiel R., Raúl. Coordinadores Historia de la educación pública en México (1876-1976). México,Fondo de Cultura Económica, 1981.

Szurmuck, Mónica. y Mckee, Robert. Diccionario de Estudios culturales latinoamericanos. México.D.F., Siglo XXI, 2009.

Tortosa, Ybáñez. Et.al. XIII “Jornades de xarxes d' investigació en docència universitària. Noves estratègies organitzatives i metodològiques"La formació universitària per a respondre a la necessitat d'adaptació i canvi. Universidad de Alicante. 2015.

Torras Meri. "El delito del cuerpo". Cuerpo e identidad, Barcelona, Ediciones UAB, 2007. Universidad Nacional Autónoma de México. Escuela Nacional Preparatoria. "Programa de estudios de: literatura mexicana e iberoamericana". http://dgenp.unam.mx/planesdeestudio/sexto/1602.pdf(consultados el 16-032016).

Universidad Nacional Autónoma de México. Escuela Nacional Preparatoria. "Programa de estudios de: literatura mexicana e iberoamericana 2018". http://dgenp.unam.mx/planesdeestudio/sexto/1602.pdf consultados(Consultado el 31-01-18).

United Nations. He for She. http://www.heforshe.org/en (Consultado 10-03-2017).

Vargas, Carlos. ¿Quién es la niña de las calcetas rojas? https://www.sinembargo.mx/02-112017/3342466

Walby, Sylvia. Theorizing Patriarchy, Oxford,Basil Blackwell, 1990.

Zamora Borge, Elizabeth de la Concepción. "La construcción de identidad en la adolescencia. El reto de apropiarse de un lugar en el mundo" Revista del Colegio de Ciencias y Humanidades para el Bachillerato, pp. 57-63 https://docplayer.es/50664914La-construccion-de-identidad-en-la-adolescencia-el-reto-de-apropiarse-de-unlugar-en-el-mundo.html (consultado 4-03-2019). 